\title{
Water-Quality Assessment of the Arkansas River Basin, Southeastern Colorado, 1990-93
}

By RODERICK F. ORTIZ, MICHAEL E. LEWIS, and MARY JO RADELL

\section{U.S. GEOLOGICAL SURVEY}

Water-Resources Investigations Report 97-4111

Prepared in cooperation with the CITY OF COLORADO SPRINGS, DEPARTMENT OF UTILITIES; PUEBLO BOARD OF WATER WORKS;

SOUTHEASTERN COLORADO WATER CONSERVANCY DISTRICT; PUEBLO COUNTY, DEPARTMENT OF PLANNING AND DEVELOPMENT; CITY OF AURORA, DEPARTMENT OF UTILITIES;

ST. CHARLES MESA WATER DISTRICT;

UPPER ARKANSAS AREA COUNCIL OF GOVERNMENTS;

UPPER ARKANSAS WATER CONSERVANCY DISTRICT;

CITY OF PUEBLO, DEPARTMENT OF UTILITIES;

PUEBLO WEST METROPOLITAN DISTRICT;

FREMONT SANITATION DISTRICT;

CITY OF ROCKY FORD, CITY OF LAS ANIMAS, and the CITY OF LAMAR 


\title{
U.S. DEPARTMENT OF THE INTERIOR
}

\section{BRUCE BABBITT, Secretary}

\author{
U.S. GEOLOGICAL SURVEY
}

Thomas J. Casadevall, Acting Director

The use of firm, trade, and brand names in this report is for identification purposes only and does not constitute endorsement by the U.S. Geological Survey.

For additional information write to:

District Chief

U.S. Geological Survey

Box 25046, Mail Stop 415

Denver Federal Center

Denver, CO 80225-0046
Copies of this report can be purchased from:

U.S. Geological Survey

Information Services

Box 25286

Denver, CO 80225-0286 


\section{CONTENTS}

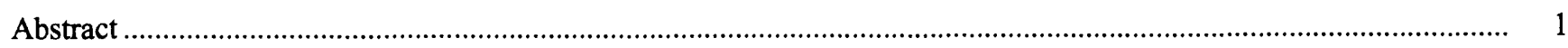

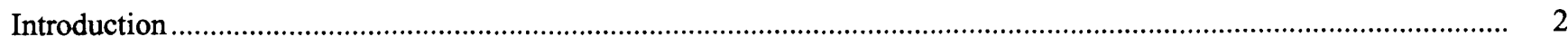

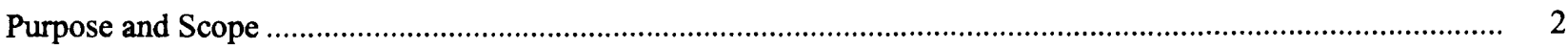

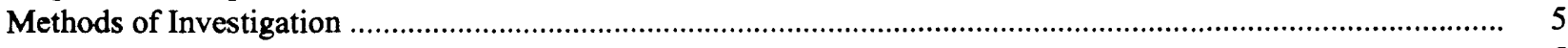

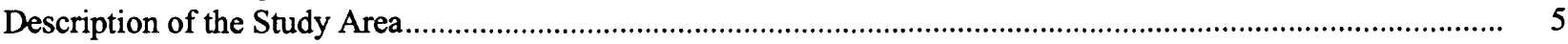

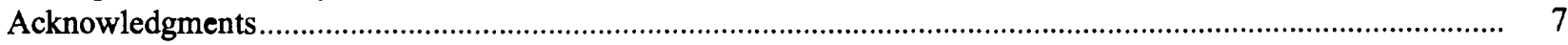

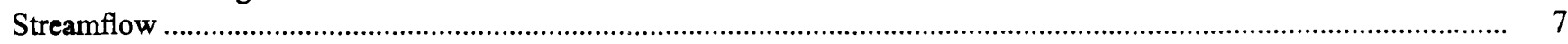

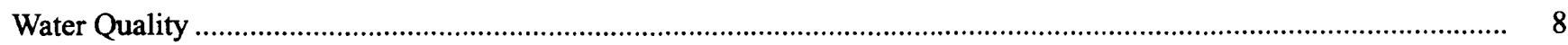

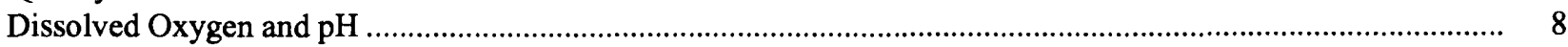

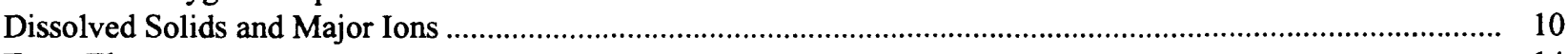

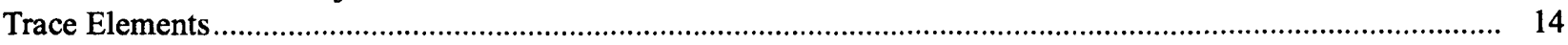

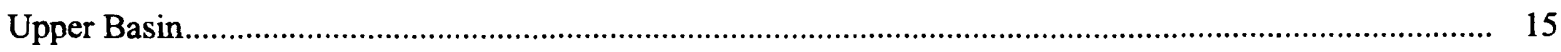

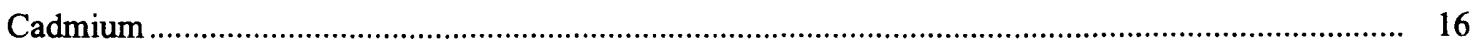

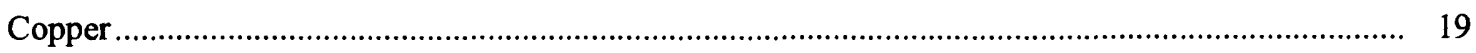

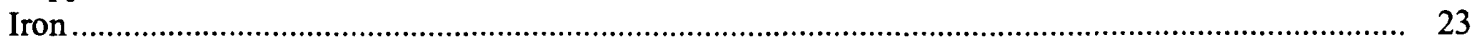

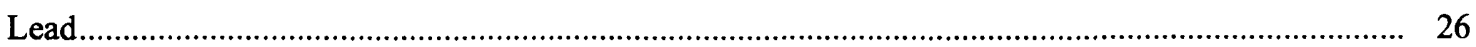

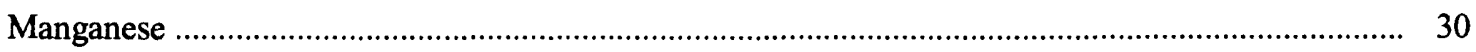

Zinc …........................................................................................................................ -33

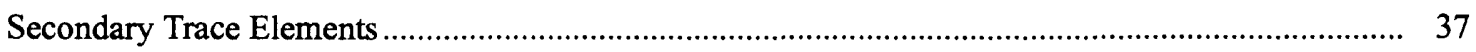

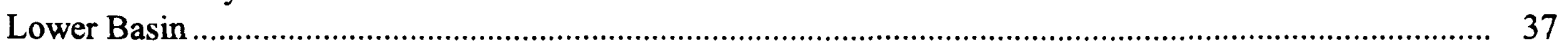

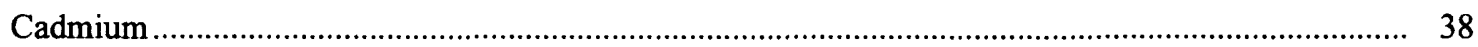

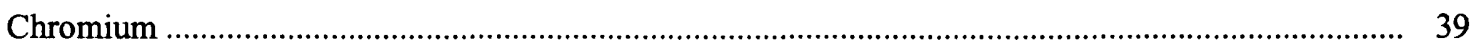

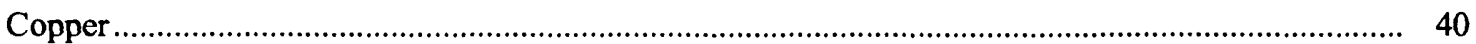

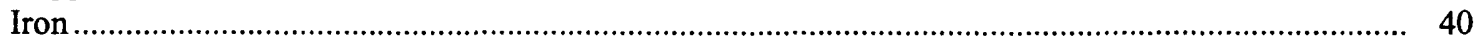

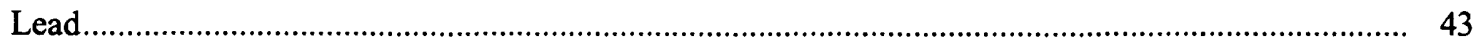

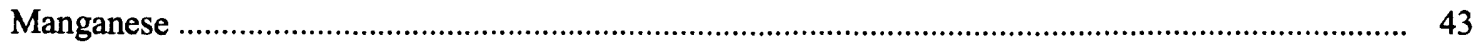

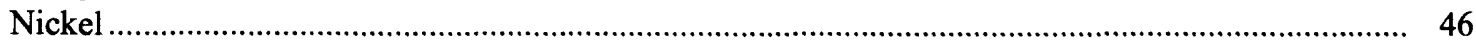

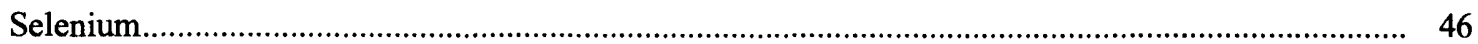

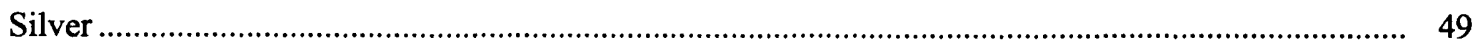

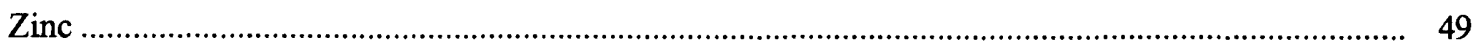

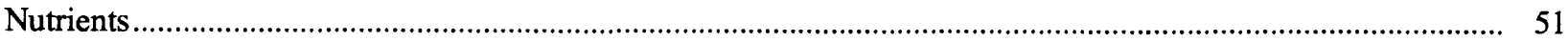

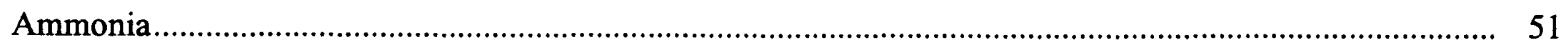

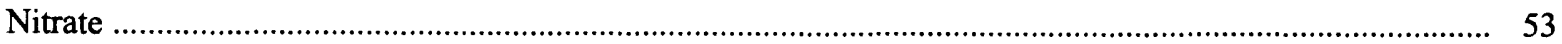

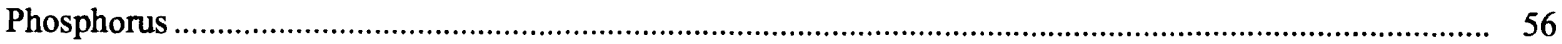

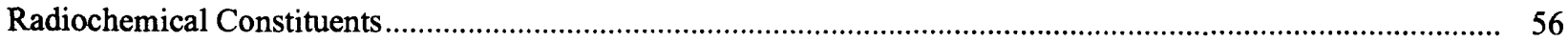

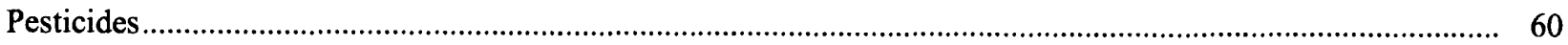

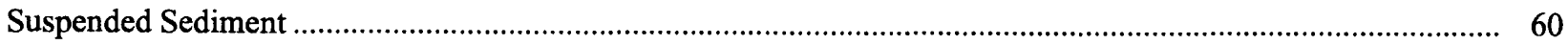

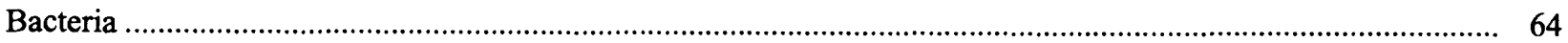

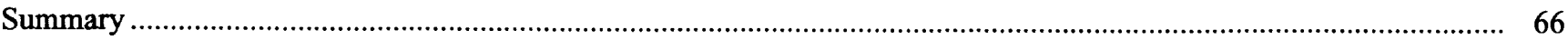

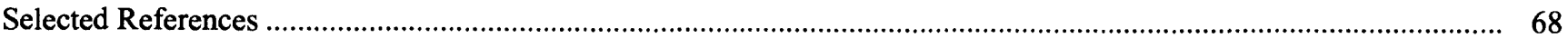

\section{PLATE}

[Plate in pocket]

1. Map showing location of selected surface-water stations in the Arkansas River Basin, Colorado, where water-quality data were collected between April 1990 and March 1993. 


\section{FIGURES}

1. Map showing location of study area.....

2. Hydrographs showing daily mean streamflow for selected sites on the Arkansas River, April 1990-March 1993 ..

3. Boxplots showing variations in $\mathrm{pH}$ in the Arkansas River, April 1990-March 1993.

4. Boxplots showing variations in dissolved-solids concentrations in the Arkansas River, April 1990-March 1993... 11

5-24. Graphs showing:

5. Comparison of median concentrations of six major ions in the Arkansas River, April 1990-March 1993 ......

6. Median dissolved- and total-recoverable cadmium concentrations by streamflow regime in the upper Arkansas River, April 1990-March 1993.

7. Median dissolved- and total-recoverable copper concentrations by streamflow regime in the upper Arkansas River, April 1990-March 1993.

8. Median percentages of dissolved copper in percentage of total-recoverable copper concentrations in the upper Arkansas River, April 1990-March 1993

9. Median dissolved- and total-recoverable iron concentrations by streamflow regime in the upper Arkansas River, April 1990-March 1993.

10. Median percentages of dissolved-iron in percentage of total-recoverable iron concentrations in the upper Arkansas River, April 1990-March 1993.

11. Median dissolved- and total-recoverable lead concentrations by streamflow regime in the upper Arkansas River, April 1990-March 1993.

12. Median percentages of dissolved lead in percentage of total-recoverable lead concentrations in the upper Arkansas River, April 1990-March 1993.

13. Median dissolved- and total-recoverable manganese concentrations by streamflow regime in the upper Arkansas River, April 1990-March 1993

14. Median percentages of dissolved manganese in percentage of total-recoverable manganese concentrations in the upper Arkansas River, April 1990-March 1993.

15. Median dissolved- and total-recoverable zinc concentrations by streamflow regime in the upper Arkansas River, April 1990-March 1993.

16. Median percentages of dissolved zinc in percentage of total-recoverable zinc concentrations in the upper Arkansas River, April 1990-March 1993

17. Median total-recoverable chromium concentrations by streamflow regime in the lower Arkansas River, April 1990-March 1993

18. Median dissolved- and total-recoverable copper concentrations by streamflow regime in the lower Arkansas River, April 1990-March 1993

19. Median dissolved- and total-recoverable iron concentrations by streamflow regime in the lower Arkansas River, April 1990-March 1993

20. Median total-recoverable lead concentrations by streamflow regime in the lower Arkansas River, April 1990-March 1993

21. Median dissolved- and total-recoverable manganese concentrations by streamflow regime in the lower Arkansas River, April 1990-March 1993

22. Median dissolved- and total-recoverable nickel concentrations by streamflow regime in the lower Arkansas River, April 1990-March 1993.

23. Median dissolved- and total-recoverable selenium concentrations by streamflow regime in the lower Arkansas River, April 1990-March 1993

24. Median dissolved- and total-recoverable zinc concentrations by streamflow regime in the lower Arkansas River, April 1990-March 1993

25. Boxplots showing variations in total-ammonia concentrations in the Arkansas River, April 1990-March 1993 .... 52

26. Graphs showing median total-ammonia and total-nitrite plus nitrate concentrations by streamflow regime in the Arkansas River, April 1990-March 1993.

27-30. Boxplots showing:

27. Variations in total-nitrite plus nitrate concentrations in the Arkansas River, April 1990-March 1993. 55

28. Variations in total-phosphorus concentrations in the Arkansas River, April 1990-March 1993 .................... 57

29. Variations in dissolved-uranium concentrations in the Arkansas River, April 1990-March 1993.................. 58

30. Variations in total-suspended-sediment concentrations in the Arkansas River, April 1990-March 1993 ........ 63 
31. Graphs showing median fecal-coliform, fecal-streptococci, and total-coliform bacteria concentrations and median

fecal-coliform concentrations by streamflow regime in the Arkansas River, April 1990-March 1993

\section{TABLES}

1. Selected surface-water sites in the Arkansas River Basin and water-quality constituents measured or analyzed between April 1990 and March 1993

2. Least-squares regression equations for dissolved-solids concentration and specific conductance for selected sites in the Arkansas River Basin, April 1990-March 1993

3. Least-squares regression equations for hardness and specific conductance for selected sites in the Arkansas River Basin, April 1990-March 1993

4. Results of Wilcoxon rank-sum test (1-tailed) of pre-treatment (April 1990-March 1992) and post-treatment (April 1992-March 1993) instantaneous streamflow and cadmium concentrations at selected sites in the upper Arkansas River Basin

5. Number of samples that exceeded acute and chronic cadmium water-quality standards in the upper Arkansas River, April 1990-March 1993

6. Average percentages of instantaneous streamflow and instantaneous total-recoverable copper load contributed to the Arkansas River by the upstream main-stem site and the intervening tributaries in the same reach, April 1990-March 1993.

7. Results of Wilcoxon rank-sum test (1-tailed) of pre-treatment (April 1990-March 1992) and post-treatment (April 1992-March 1993) instantaneous streamflow and copper concentrations at selected sites in the upper Arkansas River Basin

8. Number of samples that exceeded acute and chronic copper water-quality standards in the upper Arkansas River, April 1990-March 1993

9. Average percentages of instantaneous streamflow and instantaneous total-recoverable iron load contributed to the Arkansas River by the upstream main-stem site and the intervening tributaries in the same reach, April 1990-March 1993

10. Results of Wilcoxon rank-sum test (1-tailed) of pre-treatment (April 1990-March 1992) and post-treatment (April 1992-March 1993) instantaneous streamflow and iron concentrations at selected sites in the upper Arkansas River Basin

11. Number of samples that exceeded chronic iron water-quality standards in the upper Arkansas River, April 1990-March 1993

12. Average percentages of instantaneous streamflow and instantaneous total-recoverable lead load contributed to the Arkansas River by the upstream main-stem site and the intervening tributaries in the same reach, April 1990-March 1993.

13. Results of Wilcoxon rank-sum test (1-tailed) of pre-treatment (April 1990-March 1992) and post-treatment (April 1992-March 1993) instantaneous streamflow and lead concentrations at selected sites in the upper Arkansas River Basin

14. Number of samples that exceeded acute and chronic lead water-quality standards in the upper Arkansas River, April 1990-March 1993

15. Average percentages of instantaneous streamflow and instantaneous total-recoverable manganese load contributed to the Arkansas River by the upstream main-stem site and the intervening tributaries in the same reach, April 1990-March 1993

16. Results of Wilcoxon rank-sum test (1-tailed) of pre-treatment (April 1990-March 1992) and post-treatment (April 1992-March 1993) instantaneous streamflow and manganese concentrations at selected sites in the upper Arkansas River Basin

17. Number of samples that exceeded chronic manganese water-quality standards in the upper Arkansas River, April 1990-March 1993.

18. Average percentages of instantaneous streamflow and instantaneous total-recoverable zinc load contributed to the Arkansas River by the upstream main-stem site and the intervening tributaries in the same reach, April 1990-March 1993

19. Results of Wilcoxon rank-sum test (1-tailed) of pre-treatment (April 1990-March 1992) and post-treatment (April 1992-March 1993) instantaneous streamflow and zinc concentrations at selected sites in the upper Arkansas River Basin . 
20. Number of samples that exceeded acute and chronic zinc water-quality standards in the upper Arkansas River, April 1990-March 1993.

21. Number of samples that exceeded chronic cadmium water-quality standards in the lower Arkansas River, April 1990-March 1993

22. Number of samples that exceeded chronic iron water-quality standards in the lower Arkansas River, April 1990-March 1993

23. Number of samples that exceeded chronic manganese water-quality standards in the lower Arkansas River, April 1990-March 1993

24. Number of samples that exceeded chronic selenium water-quality standards in the lower Arkansas River, April 1990-March 1993

25. Spearman's coefficients of correlation for dissolved uranium and selected water-quality constituents in the Arkansas River, April 1990-March 1993

26. Agricultural pesticides commonly applied in the Arkansas River Basin.

27. Summary of detected pesticides for selected water-quality sites in the Arkansas River, April 1990-March 1993

28. Comparison of streamflow and suspended-sediment concentrations and loads for storms and other streamflow regimes at Catlin Dam

\section{CONVERSION FACTORS, VERTICAL DATUM, AND ABBREVIATIONS}

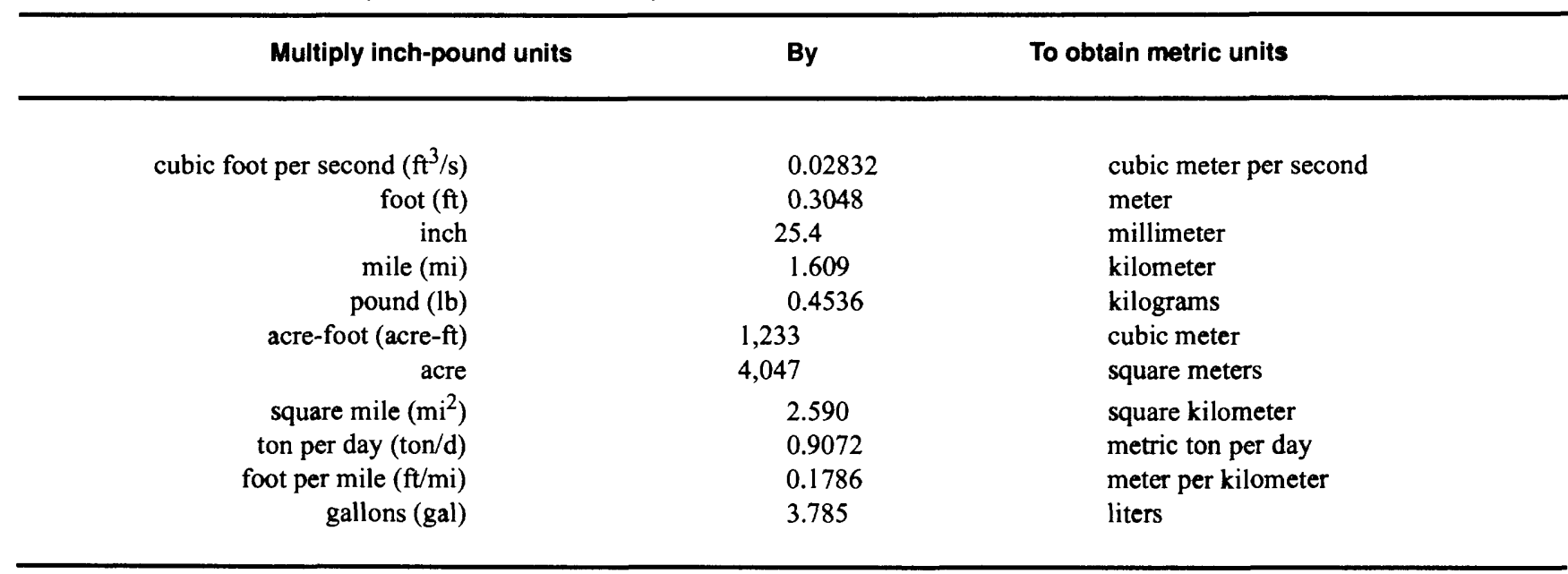

Degree Celsius $\left({ }^{\circ} \mathrm{C}\right)$ may be converted to degree Fahrenheit $\left({ }^{\circ} \mathrm{F}\right)$ by using the following equation:

$$
{ }^{\circ} \mathrm{F}=9 / 5\left({ }^{\circ} \mathrm{C}\right)+32 \text {. }
$$

Degree Fahrenheit $\left({ }^{\circ} \mathrm{F}\right)$ may be converted to degree Celsius $\left({ }^{\circ} \mathrm{C}\right)$ by using the following equation:

$$
{ }^{\circ} \mathrm{C}=5 / 9\left({ }^{\circ} \mathrm{F}-32\right) \text {. }
$$

The following terms and abbreviations also are used in this report:

calcium carbonate $\left(\mathrm{CaCO}_{3}\right)$

milligrams per liter $(\mathrm{mg} / \mathrm{L})$

micron or micrometer $(\mu \mathrm{m})$

nanometer $(\mathrm{nm})$

nanogram per liter $(\mathrm{ng} / \mathrm{L})$

micrograms per liter $(\mu \mathrm{g} / \mathrm{L})$

picocurie per liter $(\mathrm{pCi} / \mathrm{L})$

millirem per year (mrem/yr)

colonies per 100 milliliters (colonies/100 mL)

microsiemens per centimeter $(\mu \mathrm{S} / \mathrm{cm})$ 


\title{
Water-Quality Assessment of the Arkansas River Basin, Southeastern Colorado, 1990-93
}

\author{
By Roderick F. Ortiz, Michael E. Lewis, and Mary Jo Radell
}

\begin{abstract}
This report describes the spatial and temporal variations in water-quality conditions in the Arkansas River Basin between April 1990 and March 1993. Discussions focus on the site-to-site variability of water quality in the main stem of the river in the upper basin (upstream from Pueblo) and in the lower basin (from Pueblo to the Colorado-Kansas State line). Water-quality data are presented by streamflow regime. In general, the data were separated into three streamflow regimes that are defined as: low flow (October-April), snowmelt runoff (May-June), and post-snowmelt runoff (July-September). For trace elements in the upper basin, data are further separated into an early-snowmelt runoff period in April; therefore, the low-flow regime for trace elements in the upper basin is defined as October through March.

The primary cause of elevated traceelement concentrations in the upper Arkansas River is metal-laden drainage from abandoned mines and mine tailings. The spatial and temporal variability of trace-element concentrations at main-stem sites in the upper Arkansas River probably was influenced by (1) distance from the Leadville area, (2) dilution by tributaries, (3) degree of partitioning between the dissolved and particulate phases, and (4) deposition and resuspension of fluvial sediment. Overall, dissolved trace-element concentrations in the upper basin generally decreased from Leadville to Portland. Temporally, dissolved-cadmium, iron,
\end{abstract}

manganese, and zinc concentrations generally were largest during early-snowmelt runoff; totalrecoverable cadmium, copper, iron, lead, manganese, and zinc concentrations generally were largest during snowmelt runoff when resuspension of fluvial sediment occurred. Trace-element concentrations decreased significantly at several downstream main-stem sites following the completion of water-treatment facilities at the Leadville Mine Drainage Tunnel and Yak Tunnel. Although stream-water-quality standards for trace elements were exceeded in several samples collected at a number of locations in the upper basin, the vast majority of exceedances occurred during the pre-treatment period. An analysis of trace-element loads indicated that most tributaries in the upper Arkansas River Basin, particularly downstream from Granite, generally did not contribute substantial loads to the river.

Trace-element concentrations were substantially lower in the lower basin than in the upper basin. Temporally, concentrations in the Arkansas River downstream from Pueblo Reservoir generally were highest during snowmelt runoff and post-snowmelt runoff. During the lowflow regime, substantial increases in dissolvedmanganese and dissolved-iron concentrations were measured immediately downstream from John Martin Reservoir. Water in John Martin Reservoir may become anoxic during the winter months, resulting in the dissolution of iron and manganese from bottom sediments. Chronic stream-water-quality standards for most trace 
elements generally were not exceeded at most main-stem sites in the lower basin; however, total-recoverable iron and selenium standards were frequently exceeded. During storm events in the lower basin, tributaries contributed substantial amounts of trace elements to the Arkansas River.

Median concentrations of dissolved solids in the Arkansas River increased from a minimum of 62.5 milligrams per liter in the upper basin at Granite to 3,825 milligrams per liter in the lower basin near the State line. A transition from igneous and metamorphic rock to sedimentary rock, in addition to the concentrating effects of the use and reuse of water for irrigation, caused this downstream increase in dissolved-solids concentrations.

Ammonia and nitrate concentrations increased downstream but were low in comparison to State and Federal standards. Median ammonia concentrations in the Arkansas River ranged from 0.010 to 0.145 milligram per liter; median nitrate concentrations at main-stem sites ranged from 0.020 to 2.4 milligrams per liter. High concentrations of ammonia downstream from John Martin Reservoir, particularly during low-flow regimes, are indicative of anoxic conditions in the reservoir. Median total-phosphorus concentrations were relatively low in the upper basin, but they exceeded the recommended concentration for total-phosphorus in rivers ( 0.10 milligram per liter) at three sites in the lower basin.

Suspended-sediment concentrations in the Arkansas River upstream from Pueblo Reservoir were relatively low but increased downstream. Suspended-sediment concentrations typically were much larger during snowmelt runoff, owing to tributary inflow and resuspension of fluvial sediment. Suspended-sediment concentrations increased substantially during periods of elevated runoff; the largest measured concentration in the upper basin occurred during storm-runoff conditions. In the lower basin, median concentrations ranged from 19 milligrams per liter at Pueblo to 724 milligrams per liter at Catlin Dam.

\section{INTRODUCTION}

The Arkansas River drains about $25,400 \mathrm{mi}^{2}$ and flows nearly $400 \mathrm{mi}$ in Colorado before reaching the Colorado-Kansas border (fig. 1). Streamflow in the Arkansas River Basin primarily is derived from snowmelt in the mountains that border the upper region of the basin and, to a lesser extent, from summer thunderstorms that occur primarily on the eastern plains.

Water uses in the Arkansas River Basin include agricultural, commercial, domestic, industrial, livestock, mining, and power production. Although the primary water use in the basin is agricultural, many municipalities within and outside the Arkansas River Basin have become increasingly dependent on the river as a water supply. Thus, quality of water in the Arkansas River Basin has become an important consideration to a multitude of water users in Colorado.

In 1990, the U.S. Geological Survey (USGS), in cooperation with the Colorado Springs Utilities, Water Resources Department; Pueblo Board of Water Works; Southeastern Colorado Water Conservancy District; Pueblo County, Department of Planning and Development; city of Aurora, Department of Utilities; St. Charles Mesa Water District; Upper Arkansas Area Council of Governments; Upper Arkansas Water Conservancy District; city of Pueblo, Department of Utilities; Pueblo West Metropolitan District; Fremont Sanitation District; cities of Rocky Ford, Las Animas, and Lamar; and the Bureau of Reclamation, began a study to assess existing water-quality conditions in the Arkansas River Basin.

\section{Purpose and Scope}

This report describes the spatial and temporal variations in water-quality conditions in the Arkansas River Basin between April 1990 and March 1993. The primary focus of this report is the water quality of the Arkansas River; however tributary data, when appropriate, were used to assess water-quality effects on the main stem of the river.

An extensive streamflow and water-quality monitoring network was established in April 1990. Water-quality data collected at 19 main-stem, 16 tributary, and 2 mine-drainage sites were used to describe the spatial and temporal variations in water quality in the Arkansas River Basin between April 1990 and March 1993 (table 1). The Leadville Mine Drainage 

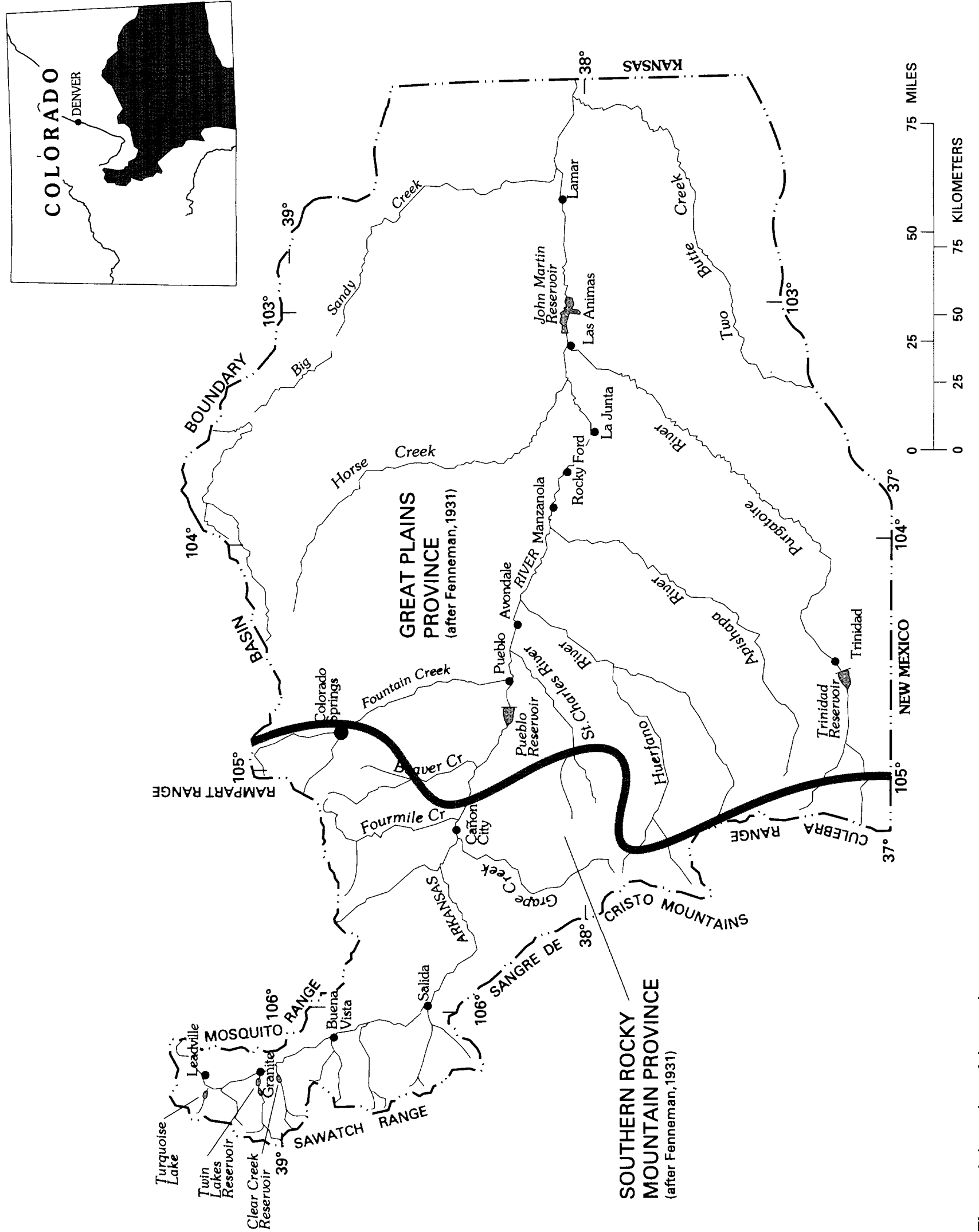
Table 1. Selected surface-water sites in the Arkansas River Basin and water-quality constituents measured or analyzed between April 1990 and March 1993

[X, routine sampling; $\mathrm{S}$, special sampling; --, not collected or analyzed]

\begin{tabular}{|c|c|c|c|c|c|c|c|c|c|}
\hline $\begin{array}{c}\text { U.S. Geological } \\
\text { Survey station } \\
\text { number } \\
\text { (see plate 1) }\end{array}$ & Site name & $\begin{array}{l}\text { Site } \\
\text { type }\end{array}$ & $\begin{array}{l}\text { Dissolved } \\
\text { solids }\end{array}$ & $\begin{array}{c}\text { Trace } \\
\text { elements }\end{array}$ & $\begin{array}{c}\text { Major } \\
\text { nutrients }\end{array}$ & $\begin{array}{l}\text { Radio- } \\
\text { chem- } \\
\text { icals }\end{array}$ & Pesticides & $\begin{array}{l}\text { Suspended } \\
\text { sediment }\end{array}$ & Bacteria \\
\hline 07079200 & $\begin{array}{l}\text { Leadville Mine } \\
\text { Drainage Tunnel }\end{array}$ & $\begin{array}{l}\text { Mine } \\
\text { drainage }\end{array}$ & $x$ & $x$ & $x$ & - & -- & -- & -- \\
\hline 07081200 & Leadville & Main stem & $x$ & $x$ & $x$ & -- & -- & $x$ & $x$ \\
\hline 07081800 & California Gulch & $\begin{array}{l}\text { Mine } \\
\text { drainage }\end{array}$ & $x$ & $x$ & $x$ & -- & -- & -- & -- \\
\hline 391226106213201 & $\begin{array}{l}\text { Lake Fork above } \\
\text { Halfmoon Creek }\end{array}$ & Tributary & $x$ & $x$ & $x$ & -- & -- & -- & -- \\
\hline 07083000 & Halfmoon Creek & Tributary & $x$ & $x$ & $x$ & -- & -- & -- & $x$ \\
\hline 391120106194901 & Iowa Gulch & Tributary & $x$ & $x$ & $x$ & -- & -- & -- & -- \\
\hline 391013106190201 & Empire Gulch & Tributary & $x$ & $x$ & $x$ & -- & -- & -- & -- \\
\hline 07083710 & Malta & Main stem & $x$ & $x$ & $x$ & -- & -- & $x$ & $x$ \\
\hline 390444106174900 & $\begin{array}{l}\text { Lake Creek below } \\
\text { Twin Lakes } \\
\text { Reservoir }\end{array}$ & Tributary & $x$ & $x$ & $x$ & -- & -- & .. & -- \\
\hline 07086000 & Granite & Main stem & $x$ & $x$ & $x$ & -- & -- & S & -- \\
\hline 07087000 & $\begin{array}{l}\text { Clear Creek below } \\
\text { Clear Creek } \\
\text { Reservoir }\end{array}$ & Tributary & $x$ & $x$ & $x$ & -- & -- & -- & -- \\
\hline 07087200 & Buena Vista & Main stem & $x$ & $x$ & $x$ & $x$ & -- & $x$ & $x$ \\
\hline 07089520 & Cottonwood Creek & Tributary & $x$ & $x$ & $x$ & -- & -- & -- & $\cdots$ \\
\hline 384427106040101 & Chalk Creek & Tributary & $x$ & $x$ & $x$ & -- & -- & -- & -- \\
\hline 07091200 & Nathrop & Main stem & $x$ & $x$ & $x$ & .- & - & -- & $x$ \\
\hline 07091500 & Salida & Main stem & $x$ & -- & $x$ & -- & -- & -- & $x$ \\
\hline 07093500 & $\begin{array}{l}\text { South Fork } \\
\quad \text { Arkansas River }\end{array}$ & Tributary & $x$ & $x$ & $x$ & -- & -- & -. & -- \\
\hline 07093700 & Wellsville & Main stem & $x$ & $x$ & $x$ & $x$ & -- & $x$ & $x$ \\
\hline 07093775 & Badger Creek & Tributary & $x$ & $x$ & $x$ & -- & -- & -- & -- \\
\hline 382917105225200 & Tallahassee Creek & Tributary & $x$ & $x$ & $x$ & -- & -- & -- & -- \\
\hline 07094500 & Parkdale & Main stem & $x$ & $x$ & $x$ & $x$ & -- & $x$ & $x$ \\
\hline 07096000 & Cañon City & Main stem & $x$ & -- & $x$ & -- & -- & -- & -- \\
\hline 07096500 & Fourmile Creek & Tributary & $x$ & $x$ & $x$ & -- & -- & -- & -- \\
\hline 07097000 & Portland & Main stem & $x$ & $x$ & $x$ & $x$ & $x$ & $x$ & $x$ \\
\hline 07099400 & $\begin{array}{l}\text { Below Pueblo } \\
\text { Reservoir }\end{array}$ & Main stem & $x$ & $x$ & $x$ & -- & -- & $S$ & $x$ \\
\hline 07099970 & Pueblo & Main stem & $x$ & $x$ & $x$ & -- & -- & $x$ & $x$ \\
\hline 07106500 & Fountain Creek & Tributary & $x$ & $x$ & $x$ & -- & -- & $x$ & $x$ \\
\hline 381510104350601 & Highway 227 & Main stem & $x$ & $x$ & $x$ & -- & -- & -- & $x$ \\
\hline 07109500 & Avondale & Main stem & $x$ & $x$ & $x$ & $x$ & $x$ & $x$ & $x$ \\
\hline 07117000 & Nepesta & Main stem & $x$ & -- & $x$ & .- & -- & -- & -- \\
\hline 380715103564701 & Apishapa River & Tributary & $x$ & s & $x$ & -- & -- & s & -- \\
\hline 07119700 & Catlin Dam & Main stem & $x$ & $x$ & $x$ & $x$ & $x$ & $x$ & $x$ \\
\hline 380111103382101 & Timpas Creek & Tributary & $x$ & S & $x$ & -- & -- & -- & -- \\
\hline 07123000 & La Junta & Main stem & $x$ & -- & $x$ & -- & -- & -- & - \\
\hline 07124000 & Las Animas & Main stem & $x$ & $x$ & $x$ & $x$ & $x$ & $x$ & $x$ \\
\hline 07128500 & Purgatoire River & Tributary & $x$ & s & $x$ & -- & -- & -- & - \\
\hline 07130500 & $\begin{array}{l}\text { Below John Martin } \\
\text { Reservoir }\end{array}$ & Main stem & $x$ & $x$ & $x$ & $x$ & $x$ & $x$ & $x$ \\
\hline
\end{tabular}


Tunnel (LMDT) and California Gulch (pl. 1), the two mine-drainage sites, were added to the network in 1991. In addition, streamflow and water-quality data collected at the Arkansas River near Coolidge, Kans., were used in the report; although the site is outside the study area boundary, these data were used to describe water-quality conditions of the downstream part of the study area.

\section{Methods of Investigation}

Data-collection activities were conducted for 3 years and included onsite measurements of streamflow, dissolved oxygen, $\mathrm{pH}$, and specific conductance at all sites as well as collection of water samples for laboratory analyses. Water samples were analyzed for concentrations of dissolved solids (including major ions), trace elements, nutrients, radiochemical constituents, pesticides, suspended sediment, and bacteria. A detailed description of the water-quality constituents listed above can be found in Dash and Ortiz (1996). Because of the diverse physiography, geology, land use, and water use in the basin, not all the sites were sampled for the same constituents. The water-quality constituents measured or analyzed at each site and the site name that will be used in this report are listed in table 1. The major changes in physiography, geology, land use, and water use generally occur between Cañon City and Pueblo. Therefore, for the purpose of this report, the Arkansas River Basin was divided into an upper and lower basin. The upper basin drains about $4,700 \mathrm{mi}^{2}$ of the Arkansas River headwaters upstream from Pueblo Reservoir. The lower basin drains almost 20,700 $\mathrm{mi}^{2}$ downstream from Pueblo Reservoir to the Colorado-Kansas State line.

Data collected for this study are presented in Dash and Ortiz (1996). Their report presents instantaneous streamflow and water-quality data for all the sampled sites as well as data collected as part of the quality-assurance program. A description of the sampling procedures, quality-assurance sampling protocols, and analytical techniques used in the study are presented in the data report.

This study was designed to provide data that represent water-quality conditions for different streamflow regimes in the Arkansas River Basin. The timing of sampling events relative to different streamflow regimes is shown in figure 2. Rainfall-runoff samples were collected when possible. Sites on the
Arkansas River were sampled eight to nine times per year. Tributaries that contributed at least 5 percent of the annual streamflow to the Arkansas River were sampled four to eight times. The two mine-drainage sites were sampled six to eight times per year. During each sampling event, water-quality samples generally were collected in a downstream order throughout the basin.

\section{Description of the Study Area}

The Arkansas River Basin is located in the central and southeastern parts of Colorado. Fenneman (1931) divided the basin into two physiographic provinces at approximately the $105^{\circ}$ parallel, which is just east of Cañon City. To the west of that parallel is the Southern Rocky Mountains Province; to the east is the Great Plains Province (fig. 1).

The Southern Rocky Mountains Province is mostly mountainous and has elevations ranging from 5,000 to more than $14,000 \mathrm{ft}$. Mean annual precipitation ranges from less than 10 inches on the valley floor to more than 40 inches at the crest of the mountains (Abbott, 1985). The area is heavily forested and underlain by igneous and metamorphic rocks. East of Salida, there is a transition from igneous and metamorphic rocks to metamorphic and sedimentary rocks. Much of the upper basin is within the Colorado mineral belt and historically has been mined. Mining operations continue in the region but on a much smaller scale than in the past.

Most of the population and related activities are concentrated along the river corridor; the major towns are Leadville, Buena Vista, Salida, and Cañon City (fig. 1). In 1990, the estimated population in the area was about 60,000 (U.S. Bureau of the Census, 1991). The area is used for many recreational activities including rafting, kayaking, and fishing. It was estimated that nearly 270,000 people rafted the Arkansas River in 1992 (Steve Reese, Colorado State Parks, oral commun., 1992). The Arkansas River, from the headwaters to Cañon City, is characterized by steepgradient, high-velocity flows that are confined to a relatively narrow rock and cobble stream channel. The river gradient averages $40 \mathrm{ft} / \mathrm{mi}$ along this stream reach. Reservoirs on Lake Fork (Turquoise Lake), Lake Creek (Twin Lakes Reservoir), and Clear Creek (Clear Creek Reservoir) (fig. 1) store native streamflow or transmountain diversion water for municipal 

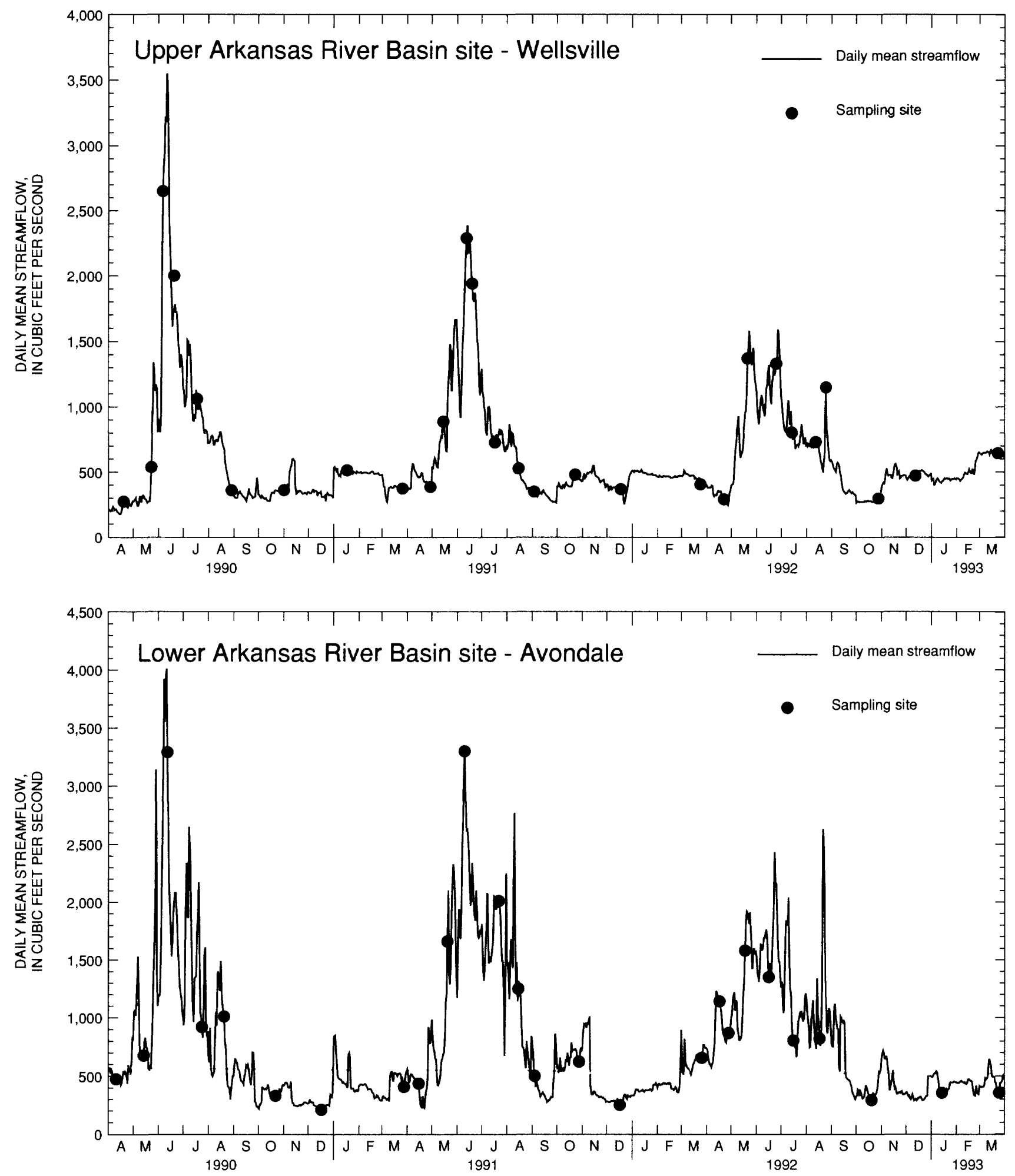

Figure 2. Daily mean streamflow for selected sites on the Arkansas River, April 1990-March 1993. 
and irrigation needs in the basin. Lake Creek contributes the largest tributary flow to the Arkansas River. A number of mine-drainage tunnels, most notably the Yak Tunnel and the Leadville Mine Drainage Tunnel, historically have supplied poor-quality water to the basin (Moran and Wentz, 1974).

East of Cañon City, the Great Plains Province ranges in elevation from 3,500 to 5,000 ft. Mean annual precipitation ranges from 10 to 14 inches (Burns, 1985). Sedimentary rock and alluvial fill underlie the region. Land use primarily is agricultural along the river corridor; the remaining areas mostly are rangeland. More than 411,000 acres in the Arkansas River Basin are irrigated, including about 56,000 irrigated acres in the upper basin (Dash and Ortiz, 1996). Most of the irrigated areas are east of Pueblo and are concentrated along the river corridor. Primary crops are wheat, corn, sorghum, and alfalfa. Fruit crops and commercial vegetables also are produced. Over 600,000 head of cattle per year have ranged in the Arkansas River Basin (Colorado Department of Agriculture, 1981), and most of the cattle and feedlots are in the lower basin, from Rocky Ford to Lamar (fig. 1). The two largest population centers are Pueblo and Colorado Springs (fig. 1). These two cities account for more than 70 percent of the 641,720 people in the Arkansas River Basin (U.S. Bureau of the Census, 1991). Pueblo is located on the main stem of the Arkansas River downstream from Pueblo Reservoir at the confluence with Fountain Creek. Colorado Springs is located on Fountain Creek 40 mi upstream from the confluence. On the west edge of the Great Plains Province, east of Cañon City, the gradient of the streambed decreases to less than $9 \mathrm{ft} / \mathrm{mi}$ as the river flows out of the mountains and onto the eastern plains. Just upstream from Pueblo, the river flows into the 357,678 acre-ft Pueblo Reservoir (fig. 1). The reservoir is a multipurpose facility completed in 1975 as part of the Fryingpan-Arkansas project. Fountain Creek flows into the Arkansas River within the city limits of Pueblo. Downstream from Fountain Creek, the stream channel changes from a rock and cobble bottom to a shifting sand channel that meanders along the alluvial flood plain. Numerous diversion structures between Avondale and La Junta (fig. 1) remove water from the river for irrigation purposes. In terms of streamflow contribution to the Arkansas River, some of the larger tributaries include Fountain Creek, Timpas Creek, and the Purgatoire River (pl. 1). The Purgatoire River flows into the Arkansas River just upstream from the 615,500-acre-ft John Martin Reservoir (fig. 1), which was completed in 1943 by the U.S. Army Corps of Engineers as a multipurpose project. Generally, recreational activities on the Arkansas River east of Cañon City are concentrated at the two main-stem reservoirs.

\section{Acknowledgments}

The authors would like to thank the many individuals who assisted in the collection of these data. Thanks to hydrographers Frank Kipple and Anthony Gutierrez of the State of Colorado for their samplecollection activities. Additionally, thanks are extended to Paul Martin and George Woods of the Pueblo Board of Water Works for their excellent work collecting numerous water-quality samples in the upper basin. Finally, thanks to Jeffery West, Charles M. Moore, and Matthew Kurchinski of the USGS for their tireless efforts under harsh field conditions.

\section{STREAMFLOW}

Precipitation and transmountain diversions are the principal sources of water in the upper Arkansas River Basin. Snowfall during winter produces a deep snowpack in the mountains that subsequently melts to supply most of the total annual streamflow in the basin. Transmountain diversions from the Colorado River Basin are supplied from several sources high in the basin. Much of this water is routed through Turquoise Lake to Twin Lakes Reservoir (fig. 1) through closed conduit for the purpose of generating power and for storage to meet downstream irrigation and municipal-supply demands (Abbott, 1985). Several open channels also transport water from the Colorado River Basin to the Arkansas River Basin. During the study period, April 1990-March 1993, the monthly mean streamflow of the Arkansas River in the upper basin ranged from $70 \mathrm{ft}^{3} / \mathrm{s}$ at Leadville to 688 $\mathrm{ft}^{3} / \mathrm{s}$ at Parkdale (Ugland and others, 1991, 1992, and 1993). Water released from Twin Lakes Reservoir by way of Lake Creek is the largest source of tributary flow to the upper Arkansas River. The monthly mean reservoir release from Twin Lakes Reservoir during the study period was $284 \mathrm{ft}^{3} / \mathrm{s}$ (Ugland and others, 1991, 1992, and 1993). These reservoir releases represented about 45 percent of the annual flow at Granite, 
the next downstream main-stem site, and about 35 percent of the total annual flow at Portland, the site farthest downstream in the upper basin.

Streamflow in the lower Arkansas River Basin is highly regulated by storage and release operations at Pueblo Reservoir and John Martin Reservoir. Surfacewater diversions and return flows downstream from Pueblo Reservoir have a pronounced effect on the streamflow of the Arkansas River. Irrigation diversions downstream from Pueblo Reservoir substantially decrease streamflow in the river. Irrigation return flows can make up a majority of the streamflow downstream from Manzanola during certain times of the year (Cain, 1985). During the study period, the monthly mean streamflow of the Arkansas River between Pueblo Reservoir and John Martin Reservoir ranged from $784 \mathrm{ft}^{3} / \mathrm{s}$ at Avondale to $201 \mathrm{ft}^{3} / \mathrm{s}$ at Las Animas (Ugland and others, 1991, 1992, and 1993). The monthly mean streamflow near the ColoradoKansas State line was about $130 \mathrm{ft}^{3} / \mathrm{s}$. In the lower basin, the largest tributary to the river was Fountain Creek, which contributed about 15 percent of the annual streamflow at Avondale.

Streamflow in the Arkansas River exhibits considerable temporal variability. During October into April, streamflow is at an annual minimum and is maintained by natural base flow and reservoir releases. In April, however, streamflow begins to increase in the upper basin as lower elevation snow begins to melt. The importance of this early snowmelt runoff, or "flushing" regime, on the water quality of the Arkansas River is discussed in the "Trace Elements" section of this report. Streamflow typically is at its annual maximum during snowmelt runoff in May and June. Peak runoff generally occurs during the second week in June. During July through September, streamflow includes decreasing amounts of snowmelt and is augmented with releases of stored water. During this time, streamflow can increase substantially over short periods of time following intense rainstorms and subsequent runoff from tributaries. During July through September, most streamflow in the lower basin generally is diverted for irrigation.

\section{WATER QUALITY}

Water-quality data in this report are presented by streamflow regime. In general, the data were divided into three streamflow regimes that are defined as low flow (October-April), snowmelt runoff (MayJune), and post-snowmelt runoff (July-September). However, the temporal analysis of trace elements in the upper basin was defined somewhat differently because of unique transport mechanisms. For trace elements in the upper basin, data are further divided into a pre-snowmelt runoff period in April; therefore, the low-flow regime for trace elements in the upper basin is defined as October through March. The transport characteristics for trace elements are discussed in greater detail in the "Trace Elements" section of this report.

Statistical comparisons of selected water-quality properties and concentrations of constituents were made between sites in the Arkansas River Basin. Most statistical comparisons were made using Tukey's studentized range test (SAS Institute, Inc., 1985) with an alpha level of 0.05 to determine whether the variations in concentrations that occurred among sites were significantly different.

\section{Dissolved Oxygen and pH}

Dissolved-oxygen concentration in water is a function of temperature and pressure, and to a lesser degree, the concentration of other solutes (Hem, 1985). Overall, the waters of the Arkansas River Basin were well oxygenated. Streamflow in high-gradient streams in the upper basin supplied sufficient amounts of atmospheric oxygen to saturate the water column. In some cases, the water was supersaturated with dissolved oxygen because of photosynthetic activity. In the lower basin, the river continued to be well oxygenated even though stream velocities and aeration decreased (Dash and Ortiz, 1996). Aquatic-life standards set by the Colorado Department of Health (1994) for the Arkansas River state that dissolvedoxygen concentrations should not decrease below 5 to $6 \mathrm{mg} / \mathrm{L}$; instantaneous dissolved-oxygen concentrations for all main-stem sites in the basin ranged from 6.1 to $14.7 \mathrm{mg} / \mathrm{L}$.

The $\mathrm{pH}$ of the Arkansas River was near neutral to slightly alkaline; median $\mathrm{pH}$ values at main-stem sites in the upper basin typically ranged from 7.9 to 8.5 (fig. 3). In the Leadville area, $\mathrm{pH}$ of the Arkansas River was slightly alkaline because mine-drainage water from the LMDT is neutral, and the Yak Tunnel drainage, which is acidic, was neutralized before reaching the river. The lowest median $\mathrm{pH}$ in the upper 


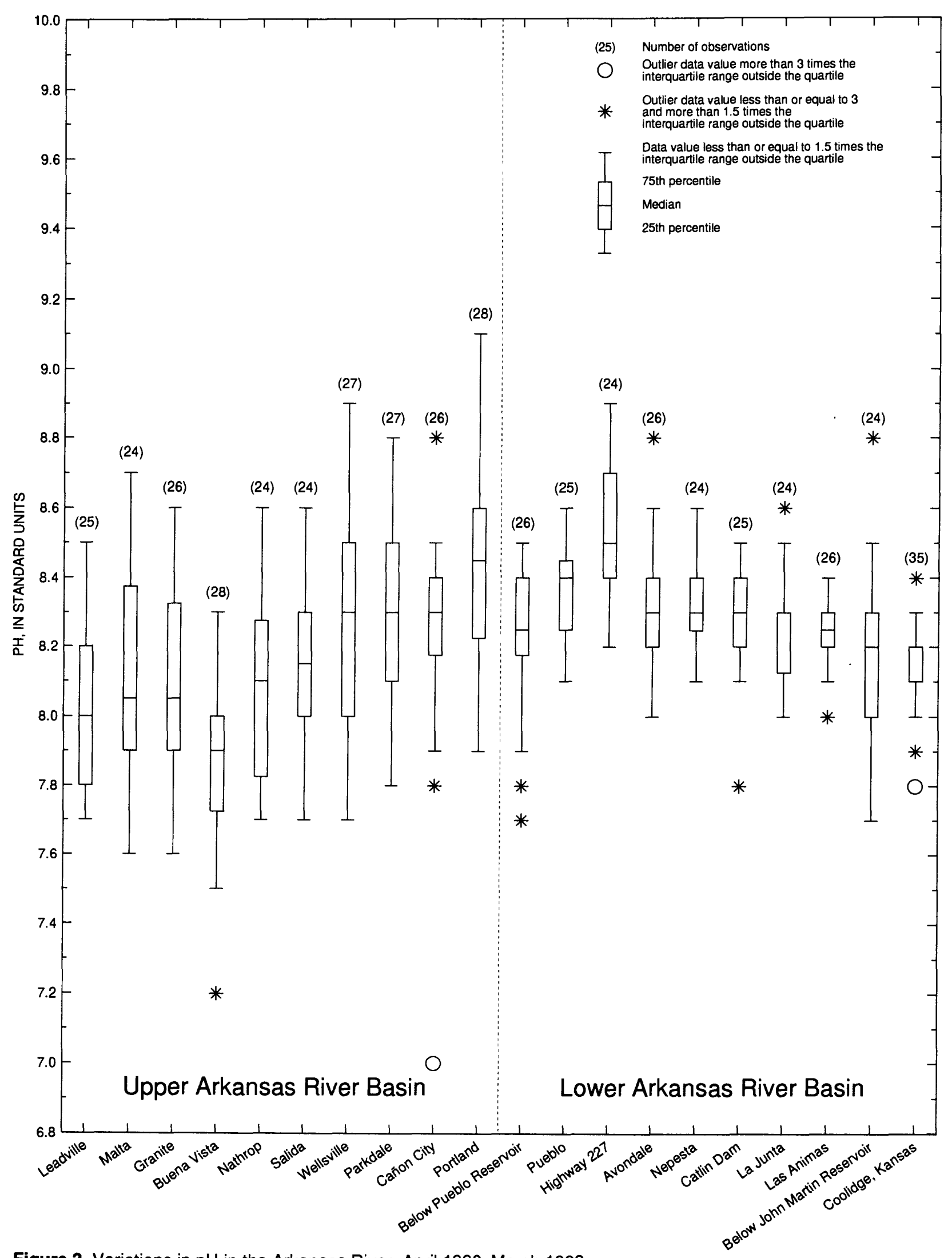

Figure 3. Variations in pH in the Arkansas River, April 1990-March 1993. 
basin occurred in the vicinity of Buena Vista before increasing because of increased bicarbonate sources downstream. In the upper basin, the highest median $\mathrm{pH}$ occurred at Portland. In the lower basin, the median $\mathrm{pH}$ of the Arkansas River ranged from 8.2 at Coolidge, Kans., and the site Below John Martin Reservoir to 8.5 at Highway 227. The pH of the Arkansas River typically was lower during the snowmelt-runoff regime because of the lower $\mathrm{pH}$ of snowmelt runoff. Instantaneous $\mathrm{pH}$ values for main-stem sites generally were within the acceptable range (6.59.0) for in-stream water quality set by the State of Colorado (Colorado Department of Health, 1994).

\section{Dissolved Solids and Major lons}

Water samples were collected and analyzed for dissolved-solids concentrations at all sites in the Arkansas River Basin. Analysis for concentrations of major ions was done for main-stem sites, but most tributary sites were not sampled for major ions. Calcium, magnesium, sodium, bicarbonate, sulfate, and chloride were the major ions analyzed. Potassium and fluoride were not analyzed because historical data indicated that the concentrations were not substantial in the basin.

Dissolved-solids concentrations in the Arkansas River are affected by many factors, including runoff from snowmelt or rainfall, geology, land and water use, mine drainage, and inflow from ground water (Crouch and others, 1984). These factors resulted in distinct spatial variations of dissolved-solids concentrations in the river (fig. 4). Dissolved solids were slightly elevated at Leadville and Malta because of mineralized drainage from mines and mine tailings in the Leadville area. Downstream from Malta, dissolved-solids concentrations decreased as flow from Lake Creek (pl. 1) diluted the dissolved solids in the river. The lowest median main-stem concentration in the basin $(62.5 \mathrm{mg} / \mathrm{L})$ occurred just downstream at Granite. A gradual increase of less than $1 \mathrm{mg} / \mathrm{L}$ per mile occurred from Granite downstream to Cañon City; dissolved solids generally doubled along this 103-mi reach. The increase was due to decreased precipitation and runoff, changes in geology and chemical composition of rocks, and increased water use (Crouch and others, 1984). Measured tributaries along this reach contributed about 50 percent of the measured dissolved-solids loads. Dissolved-solids concentrations nearly doubled again along a 16-mi reach from Cañon City to Portland (about $5.5 \mathrm{mg} / \mathrm{L}$ per mile) because of a change in geology from igneous and metamorphic rock to sedimentary rock and increased return flows (Miles, 1977). Only about 35 percent of the dissolved solids along this reach could be attributed to the two measured tributaries in the reach. Inflow from ground water and unmeasured tributaries and surface return flows may account for the remaining dissolved-solids load. In the Pueblo area, median concentrations in the river increased by about 15 percent due to tributary inflow from Fountain Creek. Downstream from Pueblo, concentrations increased steadily to Catlin Dam (about $5 \mathrm{mg} / \mathrm{L}$ per mile). A 71-percent increase in median concentration occurred between Catlin Dam and La Junta (about $16 \mathrm{mg} / \mathrm{L}$ per mile) where irrigation return flows are a large portion of the streamflow. Between La Junta and Las Animas, the dissolved-solids concentration in the river increased slightly. Median dissolved-solids concentrations increased about 183 percent (about $30 \mathrm{mg} / \mathrm{L}$ per mile) from Las Animas to Coolidge, Kans. The highest median concentration in the basin was $3,825 \mathrm{mg} / \mathrm{L}$ at Coolidge. Concentration of dissolved salts resulting from the use and reuse of irrigation water throughout the lower basin resulted in a greater than tenfold increase in dissolved solids in the lower basin.

Dissolved-solids concentrations in the upper basin were lowest during snowmelt runoff and highest during low flow. Dissolved-solids concentrations generally were as much as 2.5 times larger during the low-flow regime than during snowmelt runoff. Thus, dissolved-solids concentrations were inversely proportional to streamflow in the upper basin.

In natural water, specific conductance is a good estimator of dissolved-solids concentrations (Hem, 1985). Regression models of specific conductance and dissolved-solids concentration were developed using least-squares techniques for 24 sites in the Arkansas River Basin where 15 or more paired measurements were available. A listing of the sites, regression coefficients, and various statistical qualifiers is in table 2 . All the regressions showed statistically significant $(p<0.001)$ linear relations for specific conductance and dissolved-solids concentration.

Major-ion concentrations in the Arkansas River Basin showed large spatial variations (fig. 5). In general, concentrations for all six major ions increased downstream, probably because of changing geology, 


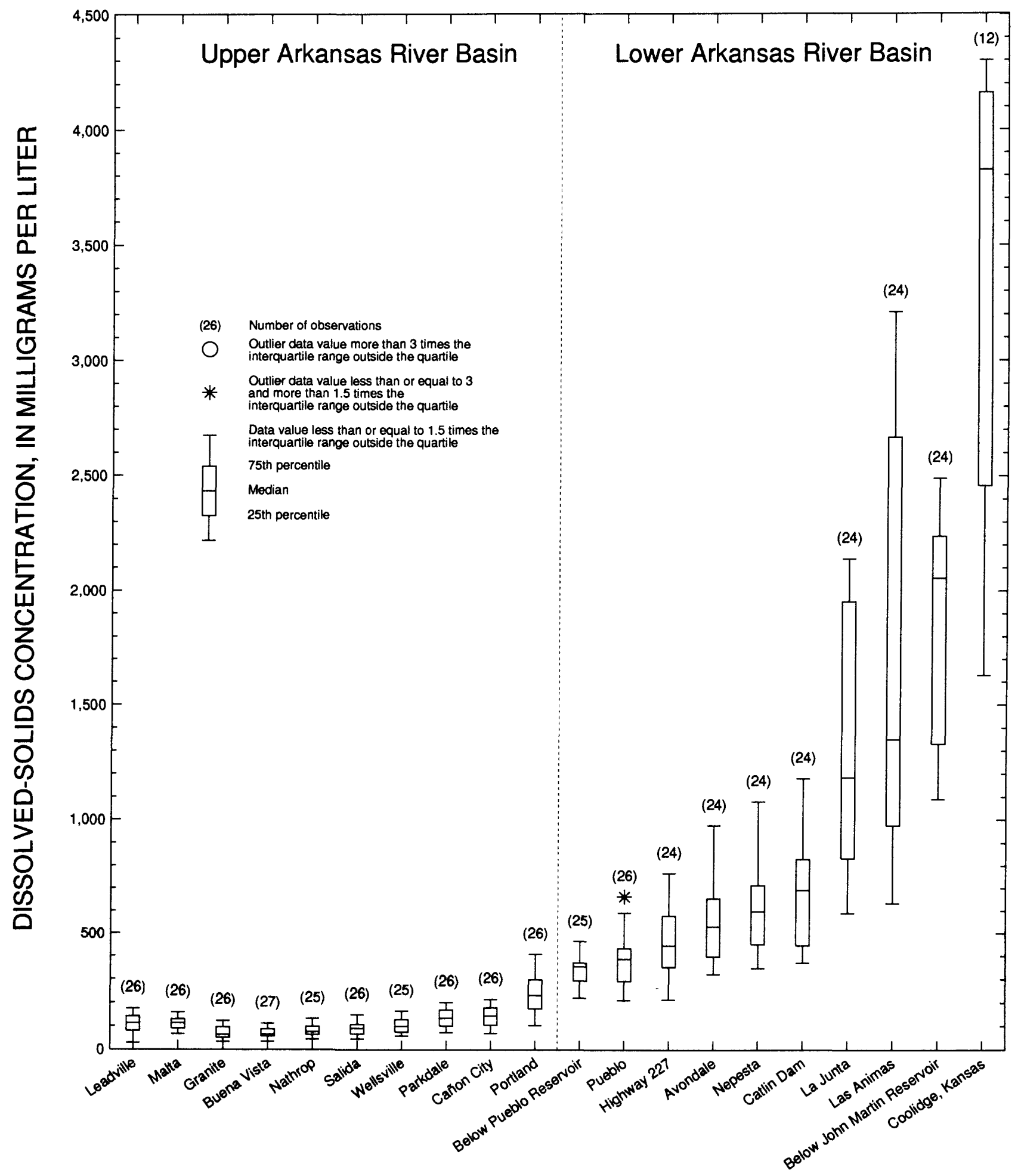

Figure 4. Variations in dissolved-solids concentrations in the Arkansas River, April 1990-March 1993. 
Table 2. Least-squares regression equations for dissolved-solids concentration and specific conductance for selected sites in the Arkansas River Basin, April 1990-March 1993

[DS, estimated dissolved solids, in milligrams per liter; $\mathrm{SC}_{\mathrm{m}}$, measured specific conductance, in microsiemens per centimeter at 25 degrees Celsius; $<$, less than]

\begin{tabular}{|c|c|c|c|c|c|c|}
\hline \multirow[t]{2}{*}{$\begin{array}{c}\text { Site name } \\
\text { (see table 1) }\end{array}$} & \multirow[t]{2}{*}{$\begin{array}{c}\text { Number of } \\
\text { palred } \\
\text { measurements }\end{array}$} & \multicolumn{2}{|c|}{$\begin{array}{c}\text { Regression coefficients in } \\
\text { the equatlon } \\
D S=a+b\left(S C_{m}\right)\end{array}$} & \multirow[t]{2}{*}{$\begin{array}{l}\text { Coefficient of } \\
\text { determination }\end{array}$} & \multirow{2}{*}{$\begin{array}{l}\text { Standard } \\
\text { error of } \\
\text { coefficlent }\end{array}$} & \multirow[t]{2}{*}{ p-value } \\
\hline & & $\mathbf{a}$ & b & & & \\
\hline Leadville Mine Drainage Tunnel & 15 & 45.9 & 0.65 & 0.78 & 0.096 & $<0.001$ \\
\hline Leadville & 26 & 18.7 & .51 & .93 & .030 & $<.001$ \\
\hline California Gulch & 15 & -166.9 & .93 & .96 & .053 & $<.001$ \\
\hline Malta & 26 & 5.6 & .55 & .83 & .051 & $<.001$ \\
\hline Granite & 26 & -15.0 & .71 & .92 & .043 & $<.001$ \\
\hline Buena Vista & 27 & -6.5 & .63 & .83 & .058 & $<.001$ \\
\hline Nathrop & 25 & -3.9 & .60 & .88 & .045 & $<.001$ \\
\hline Salida & 26 & -11.6 & .66 & .96 & .028 & $<.001$ \\
\hline Wellsville & 25 & -7.0 & .62 & .95 & .031 & $<.001$ \\
\hline Parkdale & 26 & -1.5 & .59 & .97 & .020 & $<.001$ \\
\hline Cañon City & 26 & -6.6 & .61 & .90 & .043 & $<.001$ \\
\hline Portland & 26 & -25.1 & .68 & .93 & .038 & $<.001$ \\
\hline Below Pueblo Reservoir & 24 & -37.5 & .71 & .93 & .042 & $<.001$ \\
\hline Pueblo & 26 & -92.8 & .81 & .99 & .020 & $<.001$ \\
\hline Fountain Creek & 25 & -122.7 & .78 & .97 & .026 & $<.001$ \\
\hline Highway 227 & 24 & -61.0 & .74 & .98 & .024 & $<.001$ \\
\hline Avondale & 24 & -121.3 & .83 & .98 & .025 & $<.001$ \\
\hline Nepesta & 24 & -30.3 & .73 & .87 & .059 & $<.001$ \\
\hline Catlin Dam & 24 & -120.6 & .82 & .97 & .029 & $<.001$ \\
\hline Timpas Creek & 18 & -280.1 & .95 & .98 & .032 & $<.001$ \\
\hline La Junta & 24 & -224.0 & .92 & .99 & .018 & $<.001$ \\
\hline Las Animas & 24 & -260.0 & .91 & .92 & .057 & $<.001$ \\
\hline Purgatoire River & 24 & -415.2 & 1.02 & .99 & .026 & $<.001$ \\
\hline Below John Martin Reservoir & 24 & -298.8 & .94 & .97 & .034 & $<.001$ \\
\hline
\end{tabular}

land use, and increased agricultural water use. The general downstream pattern was similar to that previously described for dissolved-solids concentrations. In the upper basin, calcium and bicarbonate were the dominant major ions (fig. 5). Calcium and bicarbonate accounted for about 60 to 80 percent of the cation and anion concentrations, respectively. The downstream increase in major-ion concentrations in the upper basin likely was caused by the transition from igneous and metamorphic rock to sedimentary rock, and from the increased use of water for municipal and agricultural purposes (Crouch and others, 1984). Downstream from Portland, the water changed from a calcium bicarbonate type to a calcium sulfate type, probably as a result of contact with marine shales that occur in the area. In the lower basin, the water changed from a calcium sulfate type to a mixed water type. While no dominant cation was detected at the Coolidge site, sulfate accounted for about 82 percent of the anions (fig. 5).

The concept of water hardness dates back many centuries but, in modern times, has been associated with the presence of calcium and magnesium (Hem, 1985). Hardness generally is defined in terms of these two constituents and is expressed in terms of an equivalent concentration of calcium carbonate. In the upper Arkansas River, median hardness values decreased between Malta $\left(90 \mathrm{mg} / \mathrm{L}\right.$ as $\left.\mathrm{CaCO}_{3}\right)$ and Granite $\left(45 \mathrm{mg} / \mathrm{L}\right.$ as $\mathrm{CaCO}_{3}$ ) because of dilution from Lake Creek inflow. Downstream from Granite to Parkdale, 

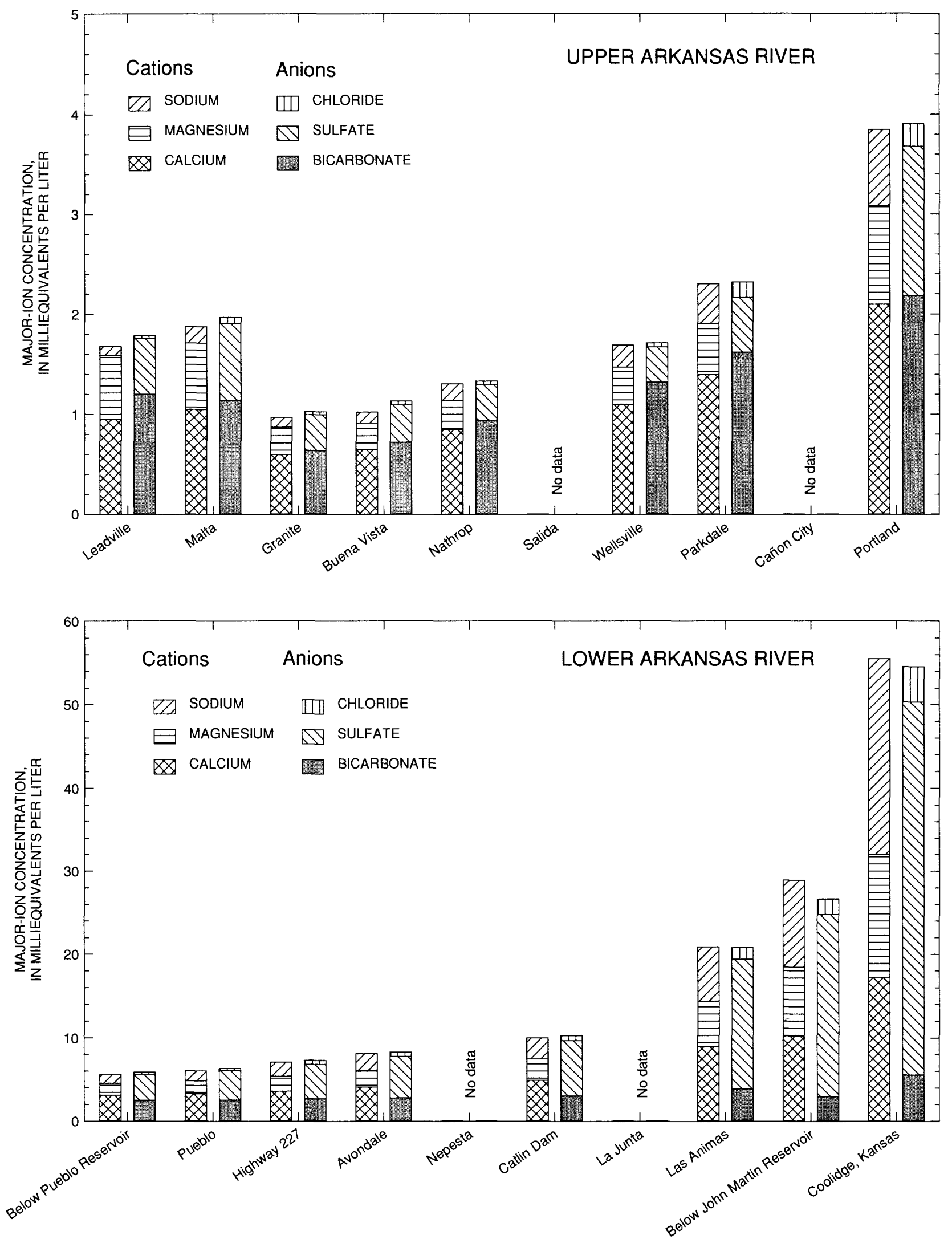

Figure 5. Comparison of median concentrations of six major ions in the Arkansas River, April 1990-March 1993. 
hardness increased steadily but remained less than $100 \mathrm{mg} / \mathrm{L}$ as $\mathrm{CaCO}_{3}$. Hardness values continued to increase downstream from Portland and throughout the lower basin. From Catlin Dam to Las Animas and from John Martin Reservoir to Coolidge, Kans., hardness increased 94 and 165 percent, respectively. The highest median hardness concentration in the river was $1,505 \mathrm{mg} / \mathrm{L}$ as $\mathrm{CaCO}_{3}$ at Coolidge. Temporally, hardness was lowest during snowmelt runoff and increased as streamflow decreased.

The toxicity of trace elements to aquatic life is affected by the hardness of the water; most metals are less toxic in water exceeding $100 \mathrm{mg} / \mathrm{L}$ as calcium carbonate (Gerhardt, 1993). In the upper basin, this relation is particularly important because of the relative sensitivity of trout to elevated metal concentrations. Hardness is an integral part of the Colorado Water Quality Control Commission's stream classifications and water-quality standards for the Arkansas River Basin (Colorado Department of Health, 1994). Many of the water-quality standards for trace elements (metals) require a hardness concentration as part of the algorithm used to calculate a particular in-stream standard. Because hardness is a calculated value that requires the chemical analysis of calcium and magnesium, it is useful to estimate hardness using an easily obtainable measurement such as specific conductance. Regression models for estimating hardness using specific conductance were developed for

15 main-stem sites and one tributary site using an ordinary least-squares regression technique. A summary of the regression coefficients and various statistical parameters is presented in table 3 . All the regressions showed statistically significant $(p<0.001)$ linear relations for specific conductance and hardness.

\section{Trace Elements}

Selected trace elements were analyzed and evaluated in different parts of the Arkansas River Basin on the basis of potential geologic and land-use effects on water quality. In the upper basin, the trace elements selected for analysis are affected mainly by local

Table 3. Least-squares regression equations for hardness and specific conductance for selected sites in the Arkansas River Basin, April 1990-March 1993

[HARD, hardness, as milligrams per liter of calcium carbonate; $\mathrm{SC}_{\mathrm{m}}$, measured specific conductance, in microsiemens per centimeter at 25 degrees Celsius; <, less than]

\begin{tabular}{|c|c|c|c|c|c|c|}
\hline \multirow[t]{2}{*}{$\begin{array}{l}\text { Site name } \\
\text { (see table 1) }\end{array}$} & \multirow[t]{2}{*}{$\begin{array}{l}\text { Number } \\
\text { of paired } \\
\text { values }\end{array}$} & \multicolumn{2}{|c|}{$\begin{array}{c}\text { Regression coefficients } \\
\text { in the equation } \\
\text { HARD }=a+b\left(S C_{m}\right)\end{array}$} & \multirow[t]{2}{*}{$\begin{array}{l}\text { Coefficient of } \\
\text { determination }\end{array}$} & \multirow[t]{2}{*}{$\begin{array}{l}\text { Standard } \\
\text { error of } \\
\text { coefficient }\end{array}$} & \multirow[t]{2}{*}{ p-value } \\
\hline & & $\mathbf{a}$ & $\mathbf{b}$ & & & \\
\hline Leadville & 26 & 0.4 & 0.46 & 0.97 & 0.017 & $<0.001$ \\
\hline Malta & 26 & 3.1 & .42 & .94 & .023 & $<.001$ \\
\hline Granite & 26 & -5.7 & .48 & .98 & .013 & $<.001$ \\
\hline Buena Vista & 27 & -5.6 & .48 & .95 & .023 & $<.001$ \\
\hline Nathrop & 25 & -4.8 & .46 & .97 & .016 & $<.001$ \\
\hline Wellsville & 26 & -5.6 & .47 & .97 & .016 & $<.001$ \\
\hline Parkdale & 26 & -0.1 & .42 & .97 & .016 & $<.001$ \\
\hline Portland & 26 & -2.3 & .41 & .98 & .012 & $<.001$ \\
\hline Below Pueblo Reservoir & 25 & 9.0 & .40 & .96 & .018 & $<.001$ \\
\hline Pueblo & 26 & -1.5 & .41 & .98 & .011 & $<.001$ \\
\hline Fountain Creek & 25 & -38.9 & .34 & .94 & .017 & $<.001$ \\
\hline Highway 227 & 24 & 47.1 & .31 & .96 & .013 & $<.001$ \\
\hline Avondale & 24 & 19.8 & .36 & .97 & .013 & $<.001$ \\
\hline Catlin Dam & 24 & -21.8 & .42 & .98 & .012 & $<.001$ \\
\hline Las Animas & 24 & 19.5 & .38 & .98 & .010 & $<.001$ \\
\hline Below John Martin Reservoir & 24 & -129.6 & .45 & .94 & .023 & $<.001$ \\
\hline
\end{tabular}


geology and mining activity. In the lower basin, the trace elements selected for analysis are affected by urban and agricultural land use and local geology. Twenty-four to 28 water samples were collected and analyzed for trace-element concentrations at most of the main-stem Arkansas River sites. Tributaries were sampled less frequently. Trace-element concentrations in and contributions from tributaries are discussed in less detail unless a tributary represented a substantial trace-element source to the main stem of the river. This discussion of trace elements focuses on downstream temporal variations in concentrations in the main stem of the Arkansas River. For the purposes of graphical presentation and statistical analysis in this report, trace-element concentrations reported as less than the reporting limit were assumed to equal 0.7 times the reporting limit (Kimball and others, 1995; Clark and Lewis, 1997).

Water samples collected in the Arkansas River Basin were analyzed for dissolved and total-recoverable trace-element concentrations. Samples analyzed for dissolved trace-element concentrations were filtered through $0.45-\mu \mathrm{m}$ membrane filters. Kimball and others (1995) reported that colloids, which are solids with effective diameters that range from $1 \mu \mathrm{m}$ to $1 \mathrm{~nm}$, affect the occurrence and transport of trace elements in the upper Arkansas River. Because colloids may pass through a $0.45-\mu \mathrm{m}$ filter, traceelement concentrations reported as dissolved might include a substantial percentage of colloidal-size particles.

A review of dissolved-trace element concentrations in field-equipment quality-assurance blanks indicated that water samples collected with a D74 nonsolenoid, brass sampler were unacceptably contaminated with dissolved copper. Therefore, all dissolved- and total-recoverable copper concentration data that were collected with the D74 sampler were not included in the analyses presented in this report. All other trace-element analytes appeared to be relatively insensitive to sampler contamination or had only minor contamination; therefore, they were judged to be acceptable and are included in the interpretations presented in this report.

Trace-element concentrations were compared to the stream-water-quality standards that have been established for the Arkansas River by the Colorado Water Quality Control Commission (Colorado Department of Health, 1994). The standards were established for individual reaches of the Arkansas River and reflect the stream classification for the individual reaches. Stream classifications include aquatic life, domestic water supply, and recreational and agricultural use. Aquatic-life standards are further divided into cold-water fisheries (upper basin) and warmwater fisheries (lower basin). Aquatic-life standards generally are calculated values that require a hardness value in the algorithm. For the purpose of this report, instantaneous hardness values were used when calculating acute and chronic aquatic-life standards.

\section{Upper Basin}

In the upper basin, historical mining of ore deposits has yielded large quantities of many valuable metals, including copper, gold, iron, lead, silver, and zinc (Tweto, 1968). Water flowing through the abandoned mines and mine tailings in the upper basin has contributed substantial quantities of cadmium, copper, iron, lead, manganese, and zinc to the Arkansas River (Moran and Wentz, 1974; Wentz, 1974). In this study, these six trace elements were selected as the primary trace elements of potential concern in the upper Arkansas River Basin. Samples analyzed for concentrations of these primary trace elements were collected from the following main-stem sites: Leadville, Malta, Granite, Buena Vista, Nathrop, Wellsville, Parkdale, and Portland (table 1). Additionally, water samples collected five times during the study at four of the eight sites were analyzed for concentrations of arsenic, chromium, mercury, nickel, selenium, and silver for the purpose of confirming that their concentrations were relatively insignificant from a water-quality perspective. Trace elements were analyzed in water samples collected from all major tributaries in the upper basin. In this study, the major tributaries in the upper basin were defined as those tributaries that contribute at least 5 to 10 percent of the annual flow in the upper Arkansas River or those that are known or suspected to be substantial sources of some trace elements, primarily owing to localized land use in the tributary drainages.

Where reported, trace-element loads were computed by multiplying the trace-element concentration of the respective sample and the instantaneous streamflow during sampling. Trace-element loads were not computed for samples with constituent concentrations that were less than the reporting limit. No load estimates are presented for cadmium because of the large number of censored total-recoverable 
cadmium concentrations. Trace-element load estimates provide a general characterization of the temporal trace-element load sources and are reported for the seven main-stem river reaches downstream from Leadville. Within each of the seven river reaches, instantaneous trace-element loads were computed for the major tributaries and for the main-stem site at the upstream end of its respective reach. These loads were compared to the trace-element load at the main-stem site located at the downstream end of its respective reach in order to estimate the percentage of traceelement load contributed by the tributaries and by the main-stem river in each of the seven reaches. Storm runoff was sampled only once in the upper basin. Because storm runoff can transport substantial amounts of trace-element-enriched sediment, storm loads are underrepresented in the load estimates. Loads are not reported for the reach upstream from Leadville because the sampling site on the East Fork of the Arkansas River was upstream from the Leadville Mine Drainage Tunnel, which is the single largest trace-element source in the reach. Therefore, trace-element loading from the East Fork of the Arkansas River could not be accurately estimated.

For the purposes of this report, the downstream temporal variability in trace-element concentrations in the upper basin is described in terms of four distinct streamflow regimes. The four regimes include low flow (October-March), early-snowmelt runoff (April), snowmelt runoff (May-June), and post-snowmelt runoff (July-September). These four regimes differ from the three streamflow regimes described earlier in this report. The distinction of an early-snowmelt runoff regime is important because lower-elevation snowmelt generally occurs during April and begins to flush abandoned mines, mine dumps, and tailing piles of trace-element-enriched water. Although the volume of water that actually flows into the river from these sources during the early-snowmelt regime is relatively small, the effect on trace-element concentrations can be substantial. Low-flow, snowmelt-runoff, and postsnowmelt-runoff regimes are similar to those described previously in the "Streamflow" section of this report. This definition of streamflow regimes for trace-element concentrations in the upper basin serves as a general guideline for the interpretation of temporal trace-element concentrations and is subject to some degree of variability due to year-to-year variability in weather conditions and reservoir operations.
The primary source of trace elements in the upper Arkansas River is metal-laden drainage from abandoned mines and mine tailings (Moran and Wentz, 1974; Wentz, 1974). Nonpoint sources of trace-element-enriched drainage in the upper basin probably are substantial because of the extensive distribution of mine tailings and mine-waste piles throughout the upper basin. However, the most substantial sources of mine drainage are located in the Leadville area and include the Leadville Mine Drainage Tunnel (LMDT) and the Yak Tunnel (Moran and Wentz, 1974; Wentz, 1974; Clements, 1991). The LMDT discharges to the East Fork of the Arkansas River upstream from Leadville, and the Yak Tunnel discharges to California Gulch near Malta (pl. 1). Water-treatment plants were operating at both sites in the spring of 1992. Both plants use a chemicalprecipitation process to remove metals from the mine drainage before the mine-drainage water is discharged to the receiving streams. The pre-treatment (April 1990-March 1992) and post-treatment (April 1992March 1993) dissolved- and total-recoverable traceelement concentration data were compared for statistical differences using the Wilcoxon rank-sum test. Statistical testing on flow-adjusted concentrations was not done because of the absence of any statistically significant explanatory variables for metal concentrations. The instantaneous streamflow associated with the water samples collected during the pre-treatment and post-treatment periods also was tested for significant differences using the Wilcoxon rank-sum test. It was assumed that streamflow had no statistically significant effect on the distribution of trace-element concentrations during the two periods because no significant difference was detected between pretreatment and post-treatment instantaneous streamflow (T.A. Cohn, U.S. Geological Survey, oral commun., 1995). In cases where more than 50 percent of the trace-element data at a given site were less than the reporting level, the rank-sum test was not done.

\section{Cadmium}

The median dissolved-cadmium concentration typically was largest at Malta and decreased substantially downstream (fig. 6). Moore and Ramamoorthy (1984) reported that dissolved-cadmium concentrations in unpolluted freshwater typically range from 10 to $100 \mathrm{ng} / \mathrm{L}$. The substantial decrease in dissolvedcadmium concentrations between Malta and Granite 

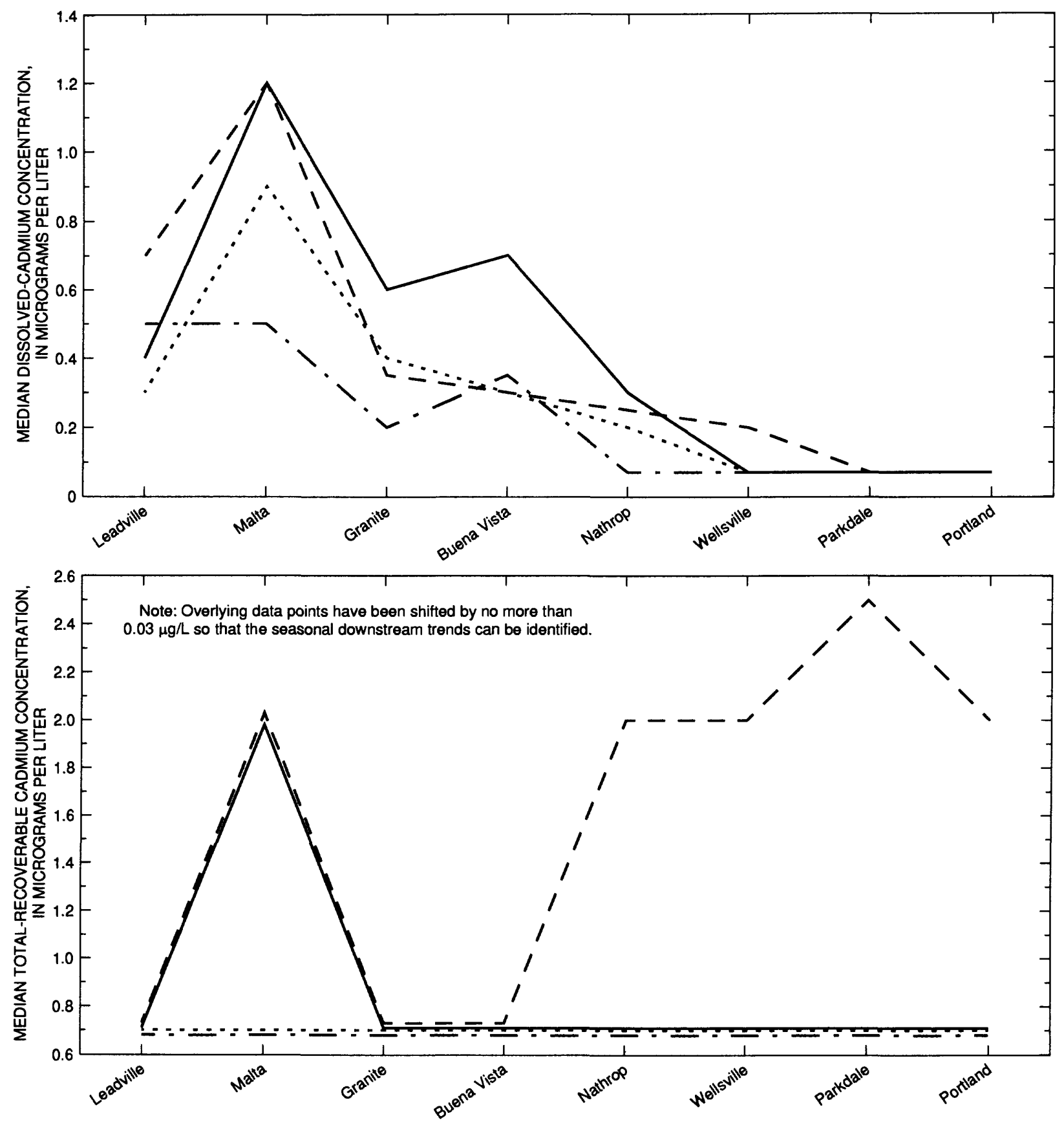

EXPLANATION

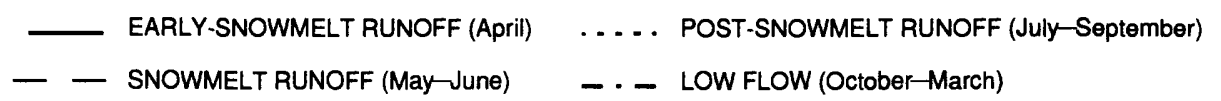

Figure 6. Median dissolved-and total-recoverable cadmium concentrations by streamflow regime in the upper Arkansas River, April 1990-March 1993. 
probably was due to dilution by Lake Creek and increased partitioning to the particulate phase. Dissolved-cadmium concentrations increased at Buena Vista. Dissolved-cadmium concentrations typically were highest during early-snowmelt runoff (fig. 6). During early-snowmelt runoff and snowmelt runoff, median total-recoverable cadmium concentrations increased substantially between Leadville and Malta (fig. 6) but were subsequently diluted by inflow from Twin Lakes (fig. 1). The median total-recoverable cadmium concentration during snowmelt runoff increased downstream from Buena Vista to a maximum of $2.5 \mu \mathrm{g} / \mathrm{L}$ at Parkdale. The downstream increase probably was caused by the resuspension of trace-element-laden sediment during high streamflow. Three characteristics of main-stem and tributary cadmium concentrations support this conclusion. First, total-recoverable cadmium concentrations increased and dissolved-cadmium concentrations decreased downstream from Buena Vista, thus indicating that particulate cadmium concentrations increased.

Second, concentrations of total-recoverable cadmium in the tributaries downstream from Buena Vista were smaller than those in the main stem (Dash and Ortiz, 1996), thus indicating that the increase in main-stem concentrations of total-recoverable cadmium probably was not caused by tributary inflow. Third, Kimball and others (1995) stated that resuspension of colloids in the main stem of the river is a "likely source of colloidal iron load during runoff" and that cadmium, copper, lead, and zinc all occur in substantial concentrations in the iron colloids. These characteristics also support measured increases in other totalrecoverable metal concentrations during the high-flow conditions of snowmelt runoff.

Cadmium concentrations decreased significantly at several sites after the mine-drainage treatment plants came on line at the LMDT and Yak Tunnel (California Gulch) (table 4). The median dissolved-cadmium concentration in the effluent from the LMDT and the Yak Tunnel (via California Gulch) decreased from 12 to $0.3 \mu \mathrm{g} / \mathrm{L}$ and from 48 to $5.2 \mu \mathrm{g} / \mathrm{L}$, respectively (table 4). Post-treatment (April 1992-March 1993) dissolved-cadmium concentrations also decreased significantly $(\mathrm{p} \leq 0.05)$ at Leadville, Malta, Granite, Buena Vista, and Nathrop (table 4). Post-treatment total-recoverable cadmium concentrations decreased significantly during posttreatment at the LMDT and at California Gulch (table 4).

Table 4. Results of Wilcoxon rank-sum test (1-tailed) of pre-treatment (April 1990-March 1992) and post-treatment (April 1992-March 1993) instantaneous streamflow and cadmium concentrations at selected sites in the upper Arkansas River Basin

$\left[\mathrm{ft}^{3} / \mathrm{s}\right.$, cubic feet per second; $\mu \mathrm{g} / \mathrm{L}$, micrograms per liter; $<$, less than; $\leq$, less than or equal to; --, test not performed; NA, not applicable]

\begin{tabular}{|c|c|c|c|c|c|c|}
\hline $\begin{array}{c}\text { Site name } \\
\text { (see table 1) }\end{array}$ & \multicolumn{2}{|c|}{ Streamtlow } & \multicolumn{2}{|c|}{ Dissolved cadmium } & \multicolumn{2}{|c|}{$\begin{array}{l}\text { Total-recoverable } \\
\text { cadmlum }\end{array}$} \\
\hline Leadville Mine Drainage Tunnel & $2.3 / 2.4$ & 0.38 & $120 \%$ & $<0.01$ & $6 \% \%$ & $<0.01$ \\
\hline California Gulch & $1.8 / 1.8$ & .50 & $48 \% 2$ & $<.01$ & 62110 & $<.01$ \\
\hline Malta & $99 / 134$ & .35 & $120 \%$ & $<.01$ & $--^{2}$ & NA \\
\hline Granite & $277 / 470$ & .45 & 0.4 .020 & .02 & $--^{2}$ & NA \\
\hline Buena Vista & $400 / 462$ & .45 & 8040.3 & $<.01$ & $--^{2}$ & $\mathrm{NA}$ \\
\hline Nathrop & $563 / 717$ & .45 & $0.2 \% 01 \%$ & .01 & $--^{2}$ & NA \\
\hline Wellsville & $524 / 742$ & .38 & $0.1 /<0.1$ & .24 & $--^{2}$ & NA \\
\hline
\end{tabular}

${ }^{1}$ Significant differences $(p \leq 0.05)$ are shaded.

${ }^{2}$ Test not performed because more than 50 percent of the data were less than the reporting level. 
During the study period, the incidence of dissolved-cadmium concentrations that exceeded stream-water-quality standards was relatively small (table 5). Only one sample exceeded the acute standard (Leadville), whereas two samples at Leadville, three samples at Granite, and two samples at Buena Vista exceeded the chronic standard (table 5). All exceedances occurred during the pre-treatment period (April 1990-March 1992). There was no obvious temporal pattern associated with these exceedances of water-quality standards.

Table 5. Number of samples that exceeded acute and chronic cadmium water-quality standards in the upper Arkansas River, April 1990-March 1993

\begin{tabular}{|c|c|c|c|}
\hline \multirow{2}{*}{$\begin{array}{l}\text { Site name } \\
\text { (see table 1) }\end{array}$} & \multirow{2}{*}{$\begin{array}{l}\text { Number } \\
\text { of samples } \\
\text { analyzed }\end{array}$} & \multicolumn{2}{|c|}{$\begin{array}{l}\text { Number of samples that } \\
\text { exceeded standard }{ }^{1}\end{array}$} \\
\hline & & $\begin{array}{c}\text { Acute } \\
\text { standard }\end{array}$ & $\begin{array}{l}\text { Chronic } \\
\text { standard }\end{array}$ \\
\hline Leadville & 27 & 1 & $2^{4}$ \\
\hline Malta & 26 & 0 & $0^{5}$ \\
\hline Granite & 27 & 0 & 3 \\
\hline Buena Vista & 27 & 0 & 2 \\
\hline Nathrop & 27 & 0 & 0 \\
\hline Wellsville & 27 & 0 & 0 \\
\hline Parkdale & 27 & 0 & 0 \\
\hline Portland & 26 & 0 & 0 \\
\hline \multicolumn{4}{|c|}{$\begin{array}{l}\text { Acute and chronic cadmium standards are based on dissolved- } \\
\text { cadmium concentration (Colorado Department of Health, 1994). } \\
{ }^{2} \text { Acute standard, in micrograms per liter }= \\
\mathrm{e}^{(1.128[\ln (\text { hardness) }]-2.905)}\end{array}$} \\
\hline \multicolumn{4}{|c|}{$\begin{array}{l}{ }^{3} \text { Unless noted: Chronic standard, in micrograms per liter }= \\
\mathrm{e}^{(0.7852[\ln (\text { hardness })]-3.490)}\end{array}$} \\
\hline $\begin{array}{l}{ }^{4} \text { Chronic s } \\
{ }^{5} \text { Chronic }\end{array}$ & $\begin{array}{l}\text { andard }=1.4 \mathrm{mi} \\
\text { andard }=2.3 \mathrm{mi}\end{array}$ & $\begin{array}{l}\text { ograms per lite } \\
\text { ograms per lit }\end{array}$ & \\
\hline
\end{tabular}

\section{Copper}

Median dissolved-copper concentrations increased between Leadville and Malta during the early-snowmelt, snowmelt-, and post-snowmeltrunoff regimes because of substantial copper loading from California Gulch and nonpoint sources (fig. 7). The median dissolved-copper concentration in California Gulch was $8 \mu \mathrm{g} / \mathrm{L}$ (Dash and Ortiz, 1996); in unpolluted freshwater, concentrations typically range from 0.5 to $1 \mu \mathrm{g} / \mathrm{L}$ (Moore and Ramamoorthy, 1984). During snowmelt runoff, median dissolved-copper concentrations increased from $2 \mu \mathrm{g} / \mathrm{L}$ at Leadville to $4 \mu \mathrm{g} / \mathrm{L}$ at Buena Vista. Downstream from Buena Vista, they decreased substantially (fig. 7) probably because of increased partitioning of copper to the particulate phase. Median concentrations were equal to or less than $2 \mu \mathrm{g} / \mathrm{L}$ during the other three regimes. The percentage of copper in the dissolved phase ranged from about 50 to 75 percent between Leadville and Parkdale but decreased to almost 30 percent at Portland (fig. 8). Dissolved-copper concentrations were not diluted between Malta and Granite by the substantial tributary inflow from Lake Creek because of somewhat elevated dissolved-copper concentrations ( 2 to $3 \mu \mathrm{g} / \mathrm{L}$ ) in Lake Creek (Dash and Ortiz, 1996). Median dissolved-copper concentrations were largest during snowmelt runoff (fig. 7), which is somewhat unusual because dissolved trace-element concentrations typically are inversely proportional to streamflow and are diluted by increasing streamflow. It is likely that colloidal copper, which will pass through a $0.45-\mu \mathrm{m}$ filter, increased during snowmelt runoff (Kimball and others, 1995).

Median total-recoverable copper concentrations were highest during the snowmelt-runoff regime (fig. 7). During the other three streamflow regimes, there was little difference among the median totalrecoverable copper concentrations, which ranged from 1 to $5 \mu \mathrm{g} / \mathrm{L}$ (fig. 7). During snowmelt runoff, the median total-recoverable copper concentration increased from a minimum of $4 \mu \mathrm{g} / \mathrm{L}$ at Leadville to a maximum of $12.5 \mu \mathrm{g} / \mathrm{L}$ at Parkdale (fig. 7). Although most of the measured copper load in most of the mainstem reaches was accounted for by measured tributary and main-stem loads, this was not the case in the reach from Buena Vista to Nathrop (table 6). During JulyAugust and October, the percentage of the measured copper load at Nathrop that was accounted for by main-stem loading at Buena Vista or by measured tributary loading in the reach was 57 and 40 percent, respectively. The unaccounted copper load may be from the resuspension of sediment or nonpoint sources within the reach. Downstream from Buena Vista, copper loading from the tributaries was relatively small ( $<10$ percent) compared to main-stem load contributions (table 6).

Total-recoverable copper concentrations decreased significantly during the mine-drainage post-treatment period at California Gulch. Posttreatment dissolved-copper concentrations decreased at Malta, which is immediately downstream from the mining-affected Leadville area, and total-recoverable copper concentrations decreased significantly at Malta, Buena Vista, and Nathrop (table 7). 

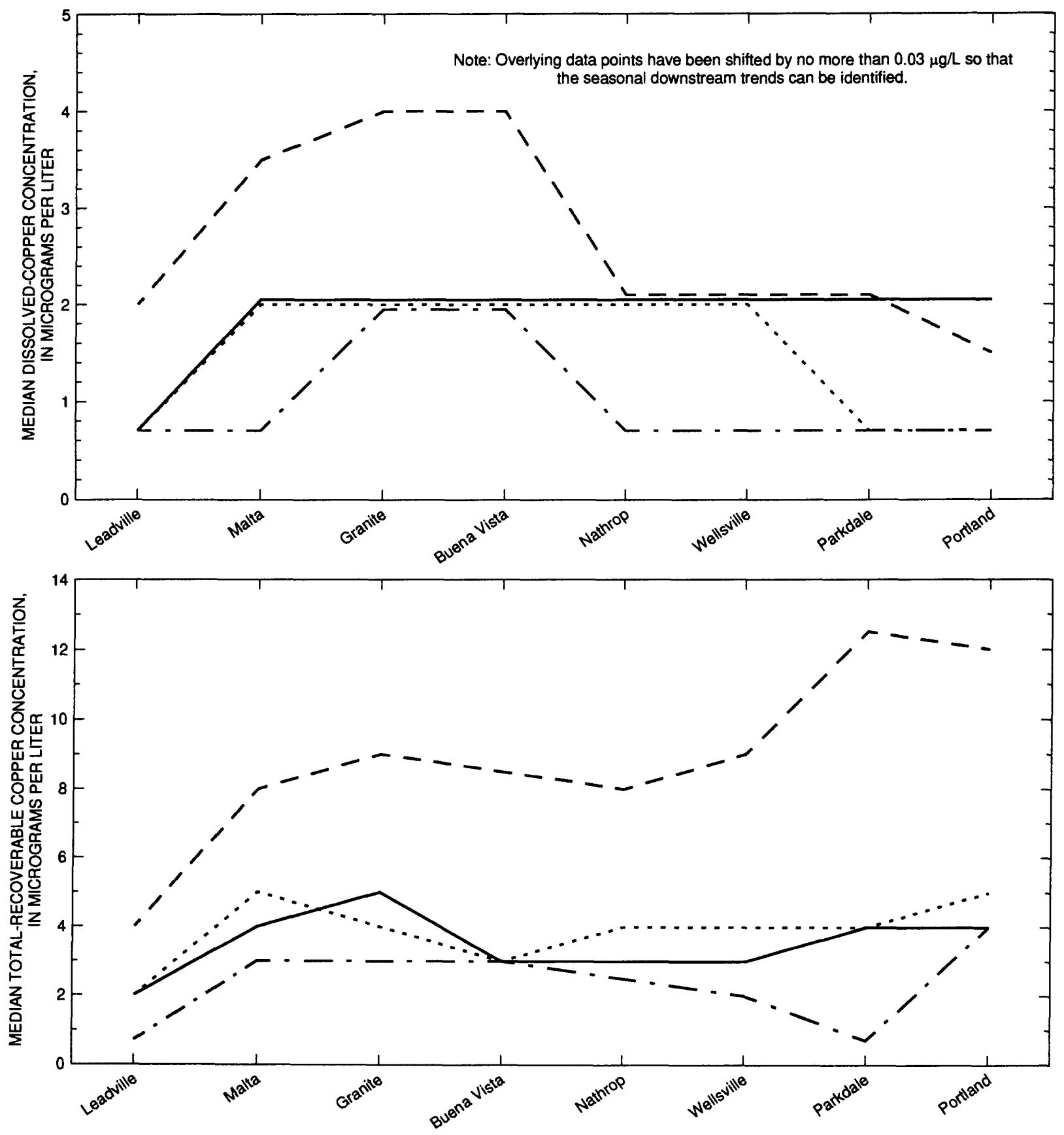

EXPLANATION

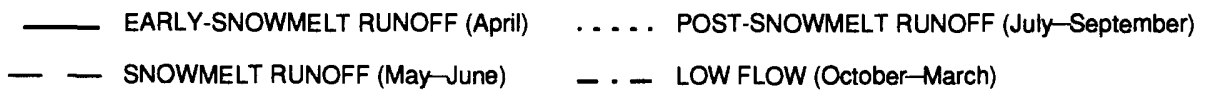

Figure 7. Median dissolved- and total-recoverable copper concentrations by streamflow regime in the upper Arkansas River, April 1990-March 1993. 


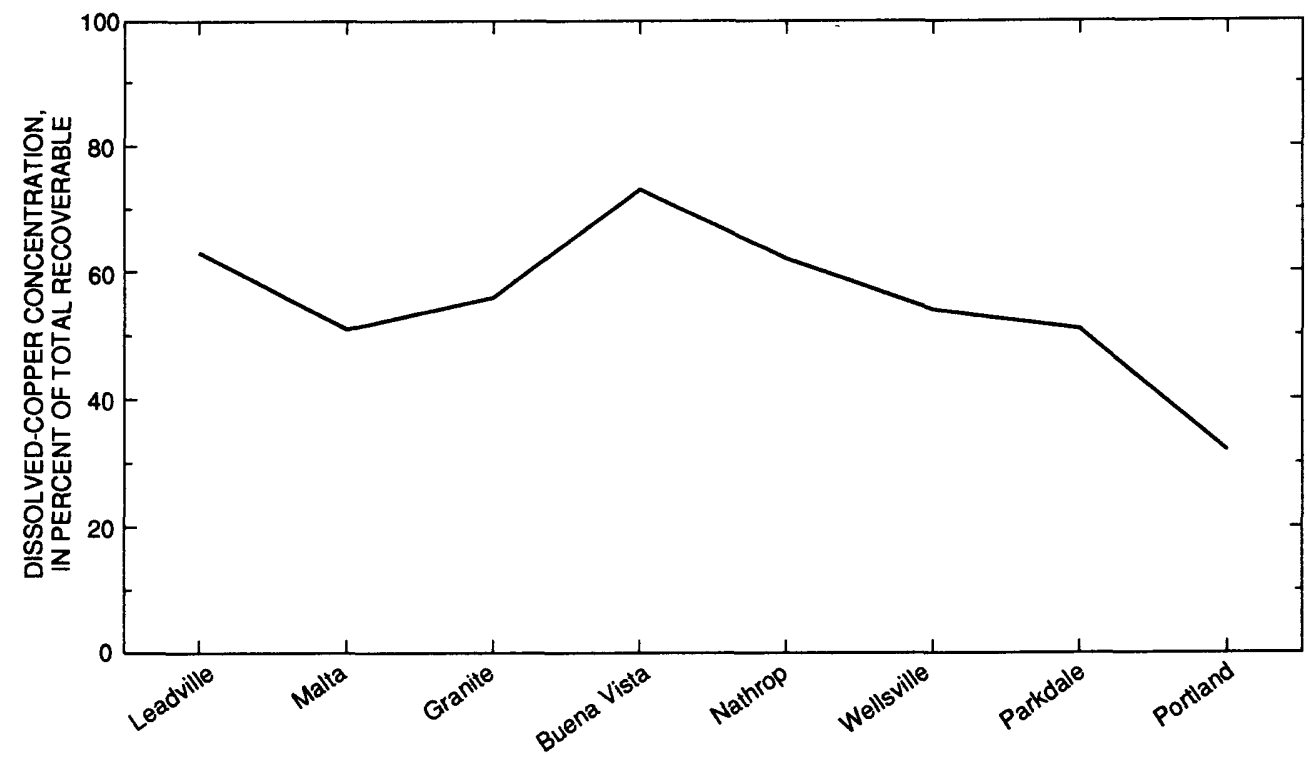

Figure 8. Median percentages of dissolved copper in percentage of total-recoverable copper concentrations in the upper Arkansas River, April 1990-March 1993.

Table 6. Average percentages of instantaneous streamflow and instantaneous total-recoverable copper load contributed to the Arkansas River by the upstream main-stem site and the intervening tributaries in the same reach, April 1990-March 1993

[Main-stem sites are in capital letters; --, insufficient data]

\begin{tabular}{|c|c|c|c|c|c|c|c|c|}
\hline \multirow{2}{*}{$\begin{array}{l}\text { Site name } \\
\text { (see table 1) }\end{array}$} & \multicolumn{4}{|c|}{$\begin{array}{l}\text { Streamflow } \\
\text { (In percent) }\end{array}$} & \multicolumn{4}{|c|}{$\begin{array}{l}\text { Total-recoverable copper load } \\
\text { (In percent) }\end{array}$} \\
\hline & April & June & $\begin{array}{l}\text { July- } \\
\text { August }\end{array}$ & October & April & June & $\begin{array}{c}\text { July- } \\
\text { August }\end{array}$ & October \\
\hline & \multicolumn{8}{|c|}{ Main-stem reach 1 (Leadville to Malta) } \\
\hline LEADVILLE & 41 & 70 & 54 & 30 & 18 & -- & 42 & 12 \\
\hline California Gulch & 2 & 1 & 2 & 1 & 100 & -- & 46 & 34 \\
\hline Lake Fork above Halfmoon Creek & 39 & 21 & 36 & 35 & 24 & -- & 34 & 20 \\
\hline Iowa Gulch & 0 & 4 & 4 & 4 & -- & -- & 10 & -- \\
\hline \multirow[t]{2}{*}{ Empire Gulch } & 0 & 2 & 1 & 0 & -- & -- & 1 & 0 \\
\hline & \multicolumn{8}{|c|}{ Main-stem reach 2 (Malta to Granite) } \\
\hline MALTA & 56 & 32 & 30 & 80 & 74 & -- & 37 & 67 \\
\hline \multirow[t]{2}{*}{ Lake Creek below Twin Lakes Reservoir } & 19 & 59 & 56 & 12 & 16 & -- & 38 & 12 \\
\hline & \multicolumn{8}{|c|}{ Main-stem reach 3 (Granite to Buena Vista) } \\
\hline GRANITE & 76 & 78 & 78 & 76 & 120 & -- & 170 & 90 \\
\hline \multirow{2}{*}{ Clear Creek below Clear Creek Reservoir } & 9 & 12 & 15 & 10 & 4 & -- & 17 & 6 \\
\hline & \multicolumn{8}{|c|}{ Main-stem reach 4 (Buena Vista to Nathrop) } \\
\hline BUENA VISTA & 78 & 92 & 80 & 53 & 95 & -- & 52 & 34 \\
\hline Cottonwood Creek & 2 & 1 & 1 & 7 & 1 & -- & 1 & 2 \\
\hline \multirow{2}{*}{ Chalk Creek } & 1 & 9 & 8 & 8 & 1 & - & 4 & 4 \\
\hline & \multicolumn{8}{|c|}{ Main-stem reach 5 (Nathrop to Wellsville) } \\
\hline NATHROP & 99 & 99 & 96 & 77 & 90 & - & 283 & 162 \\
\hline \multirow[t]{2}{*}{ South Fork Arkansas River } & 2 & 3 & 1 & 5 & 1 & -- & 6 & 2 \\
\hline & \multicolumn{8}{|c|}{ Main-stem reach 6 (Wellsville to Parkdale) } \\
\hline WELLSVILLE & 83 & 88 & 95 & 87 & 70 & -- & 90 & 124 \\
\hline Badger Creek & 3 & 0 & 1 & 2 & 3 & - & 1 & 2 \\
\hline \multirow[t]{2}{*}{ Tallahassee Creek } & 0 & 1 & 0 & 1 & 0 & -- & 0 & 0 \\
\hline & \multicolumn{8}{|c|}{ Main-stem reach 7 (Parkdale to Portland) } \\
\hline PARKDALE & 11 & 98 & 122 & 104 & 130 & -- & 116 & 30 \\
\hline Fourmile Creek & 11 & 2 & 5 & 6 & 5 & -- & 5 & 6 \\
\hline
\end{tabular}


Table 7. Results of Wilcoxon rank-sum test (1-tailed) of pre-treatment (April 1990-March 1992) and post-treatment (April 1992-March 1993) instantaneous streamflow and copper concentrations at selected sites in the upper Arkansas River Basin

[ $\mathrm{ft}^{3} / \mathrm{s}$, cubic feet per second; $\mu \mathrm{g} / \mathrm{L}$, micrograms per liter; $<$, less than; $\leq$, less than or equal to; --, test not performed; NA, not applicable]

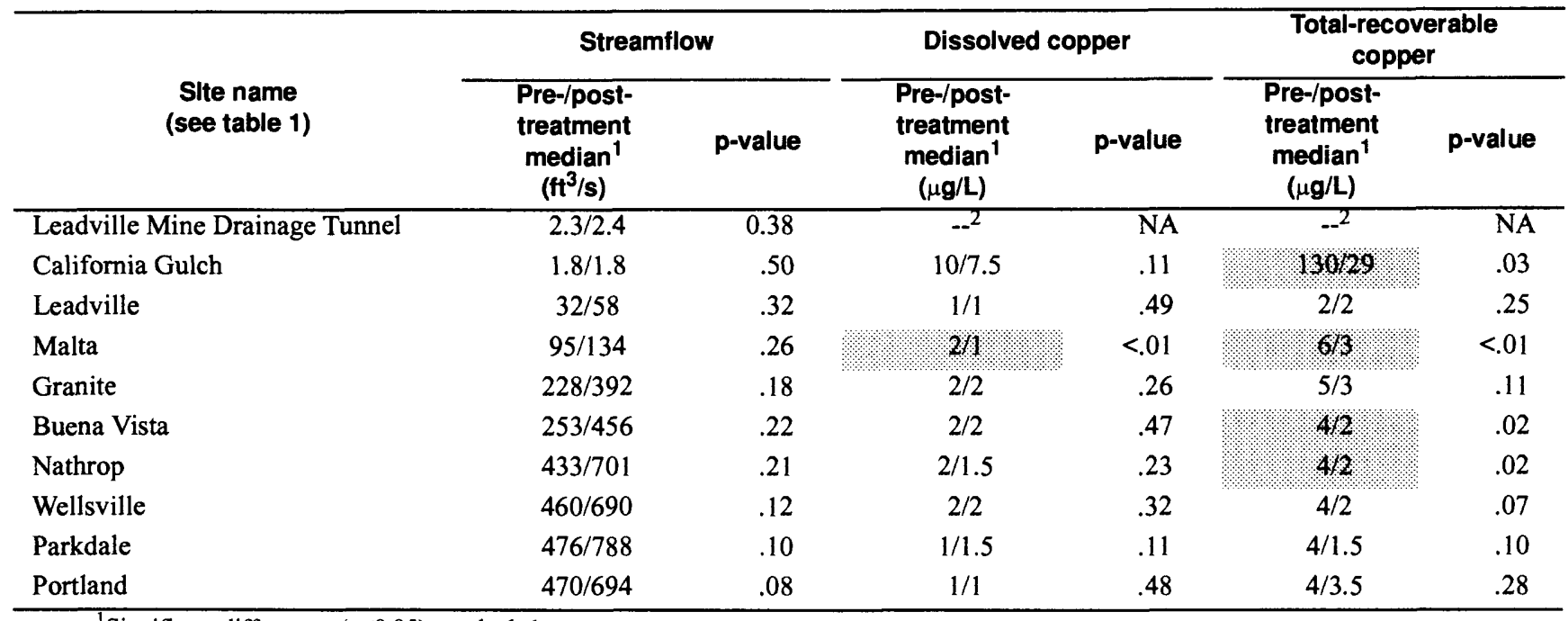

${ }^{1}$ Significant differences $(\mathrm{p} \leq 0.05)$ are shaded.

${ }^{2}$ Test could not be performed because more than 50 percent of the data were less than the reporting limit.

The incidence of dissolved-copper concentrations that exceeded stream-water-quality standards was small (table 8 ). No samples exceeded the acute copper standard, whereas only one sample collected at Nathrop in May exceeded the chronic copper standard. It is possible that more exceedances of the

copper standards occurred during the snowmeltrunoff regime, but this determination cannot be made because most of these samples were not included in the analyses due to quality-assurance concerns associated with the use of the D74 sampler.

Table 8. Number of samples that exceeded acute and chronic copper water-quality standards in the upper Arkansas River, April 1990-March 1993

\begin{tabular}{|c|c|c|c|}
\hline \multirow{2}{*}{$\begin{array}{l}\text { Slte name } \\
\text { (see table 1) }\end{array}$} & \multirow{2}{*}{$\begin{array}{c}\text { Number of samples } \\
\text { analyzed }\end{array}$} & \multicolumn{2}{|c|}{ Number of samples that exceeded standard } \\
\hline & & $\begin{array}{c}\text { Acute } \\
\text { standard }\end{array}$ & $\begin{array}{l}\text { Chronlc } \\
\text { standard }\end{array}$ \\
\hline Leadville & 24 & 0 & 0 \\
\hline Malta & 25 & 0 & 0 \\
\hline Granite & 22 & 0 & 0 \\
\hline Buena Vista & 22 & 0 & 0 \\
\hline Nathrop & 21 & 0 & 1 \\
\hline Wellsville & 22 & 0 & 0 \\
\hline Parkdale & 21 & 0 & 0 \\
\hline Portland & 21 & 0 & 0 \\
\hline
\end{tabular}

\footnotetext{
${ }^{1}$ Acute and chronic copper standards are based on dissolved-copper concentration (Colorado Department of Health, 1994).

${ }^{2}$ Acute standard, in micrograms per liter $=\mathrm{e}^{(0.9422[\ln (\text { hardness })]-1.4634)}$.

${ }^{3}$ Chronic standard, in micrograms per liter $=\mathrm{e}^{(0.8545[\ln (\text { hardness })]-1.465)}$.
} 
Iron

The median dissolved-iron concentrations were largest during early-snowmelt runoff; the maximum median concentration $(330 \mu \mathrm{g} / \mathrm{L})$ was at Leadville (fig. 9). Dissolved-iron concentrations were much smaller during the other three streamflow regimes and were not substantially different from one another (fig. 9). Median percentages of dissolved-iron concentrations decreased downstream largely because of the increased partitioning of iron to the particulate phase (fig. 10). The median percentage of iron in the dissolved phase decreased from a maximum of
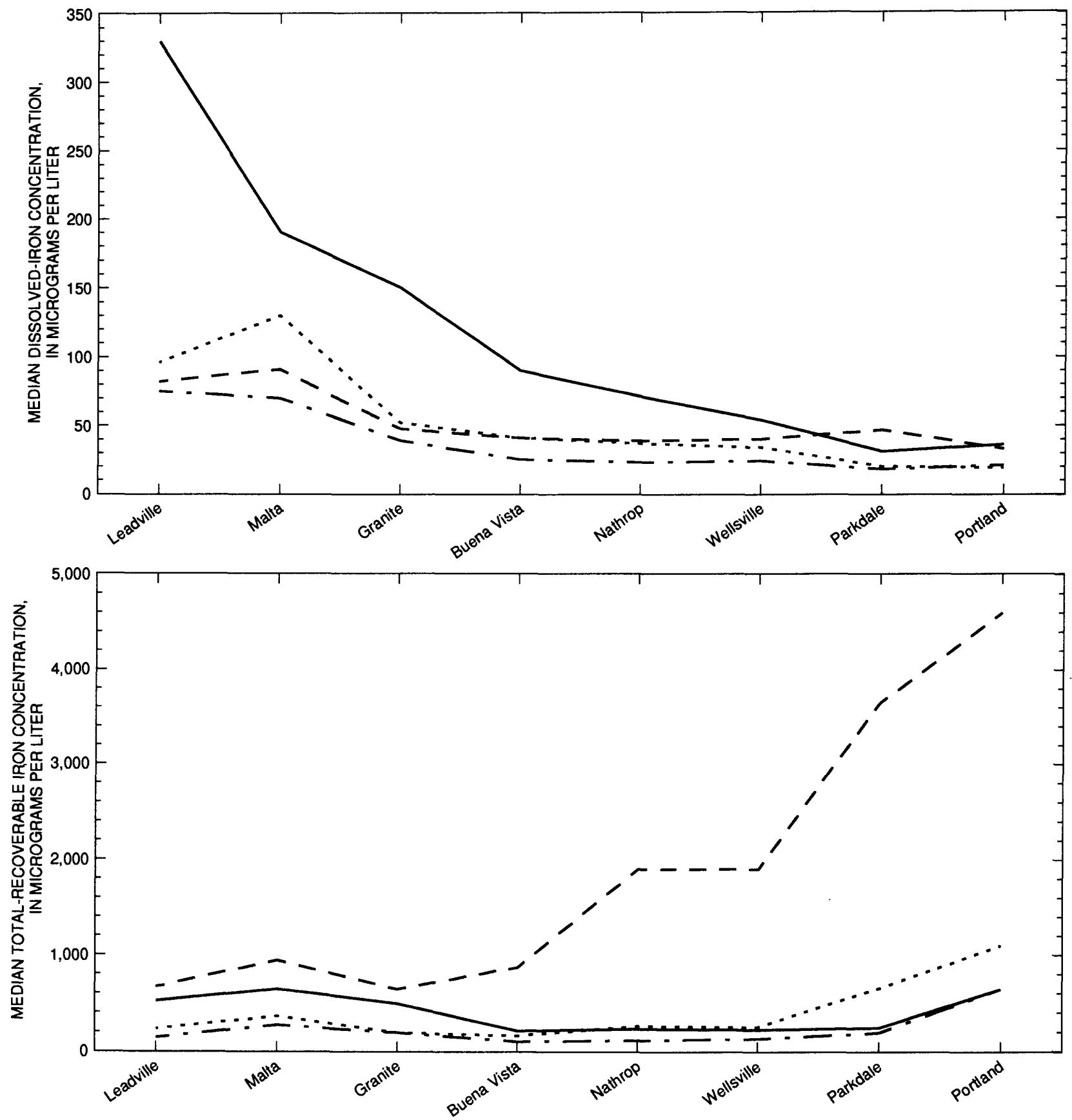

EXPLANATION

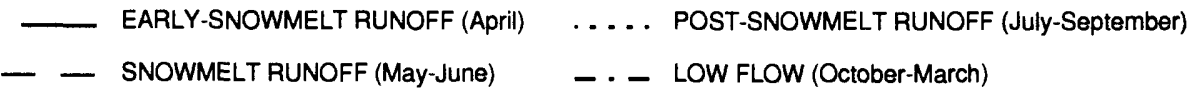

Figure 9. Median dissolved- and total-recoverable iron concentrations by streamflow regime in the upper Arkansas River, April 1990-March 1993. 


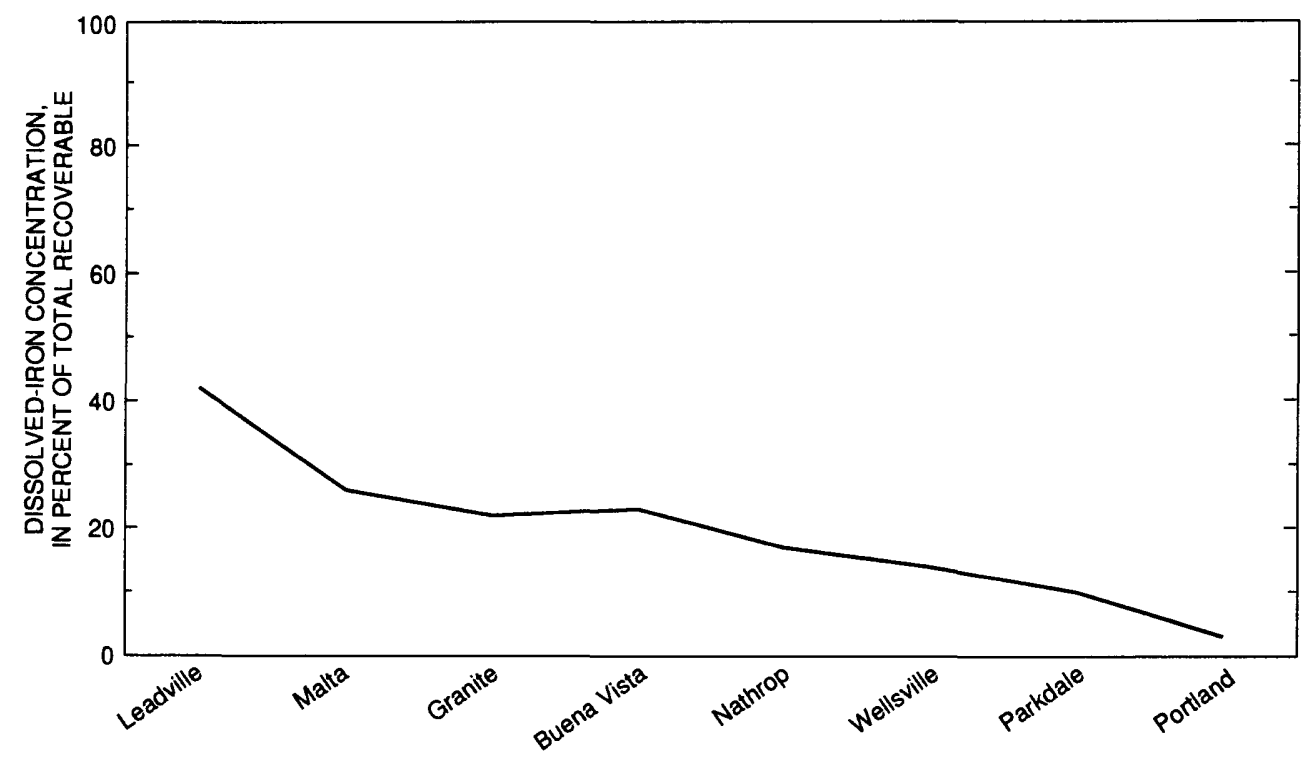

Figure 10. Median percentages of dissolved iron in percentage of total-recoverable iron concentrations in the upper Arkansas River, April 1990-March 1993.

42 percent at Leadville to a minimum of 3 percent at Portland (fig. 10). The median total-recoverable iron concentrations were largest during snowmelt runoff and increased from $665 \mu \mathrm{g} / \mathrm{L}$ at Leadville to $4,600 \mu \mathrm{g} / \mathrm{L}$ at Portland, an increase of almost 600 percent (fig. 9). Total-recoverable iron concentrations were much smaller during the other three flow regimes, and they were not substantially different from one another (fig. 9). The downstream increase in totalrecoverable iron concentrations during snowmelt runoff probably was caused by the resuspension and downstream transport of iron-enriched fluvial sediment. The elevated streamflow during snowmelt runoff has the largest potential effect on the resuspension and downstream transport of sediment. An analysis of total-recoverable iron-load contributions indicates that tributary contributions of iron typically were small ( $<10$ percent) compared to the main-stem loads (table 9) with the exception of California Gulch, Lake Fork above Halfmoon Creek, and Lake Creek below Twin Lakes Reservoir.

Dissolved and total-recoverable iron concentrations decreased significantly at the LMDT during the post-treatment period, but concentrations at California Gulch showed no significant change (table 10).
Nonpoint-source loading of iron to California Gulch from sources other than the Yak Tunnel probably contributed a substantial amount of iron, which negated the effects of the treatment plant. Iron concentrations at most main-stem Arkansas River sites were not statistically different during the pre-treatment and post-treatment periods (table 10). The results of the statistical tests of pre-treatment and post-treatment concentrations were not unexpected owing to the wide distribution of iron-enriched mine tailings and the ubiquitous nature of iron throughout the basin.

Chronic stream-water-quality standards for dissolved and total-recoverable iron were exceeded in many samples throughout the upper basin during the study period (table 11). There was no acute standard for iron. Two samples collected at Granite exceeded the chronic standard for dissolved iron $(300 \mu \mathrm{g} / \mathrm{L})$. The chronic total-recoverable iron standard $(1,000 \mu \mathrm{g} / \mathrm{L})$ was exceeded in about 7 percent of the samples collected at Leadville. The percent exceedance increased downstream to a maximum of about 42 percent at Portland (table 11). Most chronic iron-standard exceedances occurred during snowmelt runoff. 
Table 9. Average percentages of instantaneous streamflow and instantaneous total-recoverable iron load contributed to the Arkansas River by the upstream main-stem site and the intervening tributaries in the same reach, April 1990-March 1993

[Main-stem sites are in capital letters]

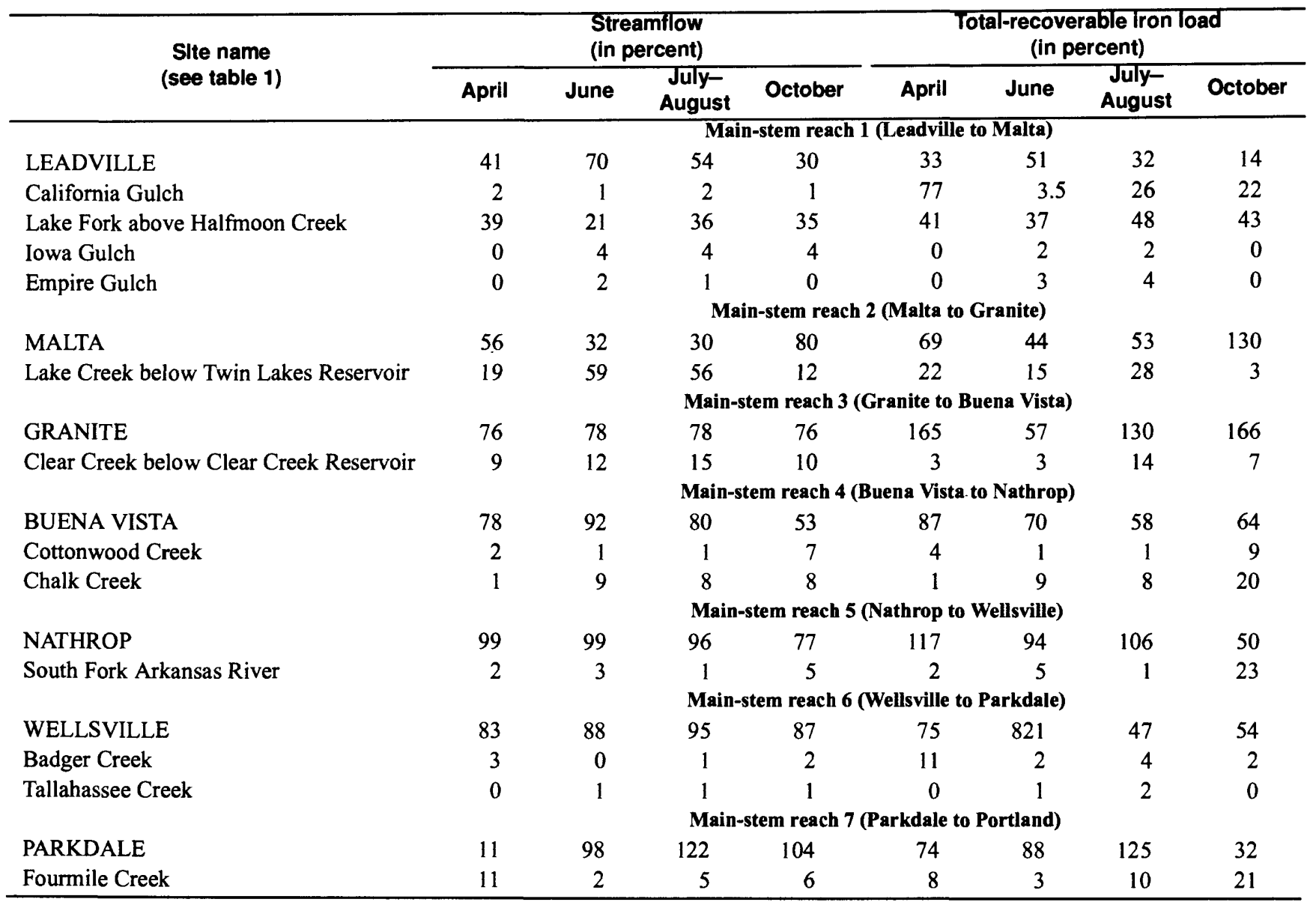

Table 10. Results of Wilcoxon rank-sum test (1-tailed) of pre-treatment (April 1990-March 1992) and post-treatment (April 1992-March 1993) instantaneous streamflow and iron concentrations at selected sites in the upper Arkansas River Basin

[ $\mathrm{ft}^{3} / \mathrm{s}$, cubic foot per second; $\mu \mathrm{g} / \mathrm{L}$, micrograms per liter; $<$, less than; $\leq$, less than or equal to]

\begin{tabular}{|c|c|c|c|c|c|c|}
\hline \multirow[b]{2}{*}{$\begin{array}{c}\text { Slte name } \\
\text { (see table 1) }\end{array}$} & \multicolumn{2}{|c|}{ Streamflow } & \multicolumn{2}{|c|}{ Dissolved Iron } & \multicolumn{2}{|c|}{ Total-recoverable Iron } \\
\hline & $\begin{array}{c}\text { Pre-/post- } \\
\text { treatment } \\
\text { median }^{1} \\
\left(\mathrm{ft}^{3} / \mathrm{s}\right)\end{array}$ & p-value & $\begin{array}{c}\text { Pre-/post- } \\
\text { treatment } \\
\text { median } 1 \\
(\mu \mathrm{g} / \mathrm{L})\end{array}$ & p-value & $\begin{array}{c}\text { Pre-/post- } \\
\text { treatment } \\
\text { medlan }^{1} \\
(\mu \mathrm{g} / \mathrm{L})\end{array}$ & p-value \\
\hline Leadville Mine Drainage Tunnel & $2.3 / 2.4$ & 0.38 & $65 \times 5 \%$ & $<0.01$ & $2100 \%$ & $<0.01$ \\
\hline California Gulch & $1.8 / 1.8$ & .50 & $69 / 40$ & .43 & $3,800 / 3,950$ & .37 \\
\hline Leadville & $70 / 58$ & .50 & $88 / 92$ & .29 & $340 / 240$ & .27 \\
\hline Malta & $99 / 134$ & .35 & $92 / 91$ & .44 & $420 / 440$ & .36 \\
\hline Granite & $277 / 470$ & .45 & $56 / 47$ & .32 & $235 / 270$ & .35 \\
\hline Buena Vista & $400 / 462$ & .45 & $36 / 41$ & .19 & $190 / 170$ & .48 \\
\hline Nathrop & $563 / 717$ & .45 & $34 / 34$ & .36 & $320 / 230$ & .25 \\
\hline Wellsville & $524 / 742$ & .38 & $30 / 38$ & .13 & $300 / 180$ & .37 \\
\hline Parkdale & $582 / 843$ & .41 & 1823 & .04 & $350 / 420$ & .38 \\
\hline Portland & $512 / 800$ & .18 & $21 / 22$ & .48 & $700 / 1,400$ & .08 \\
\hline
\end{tabular}

TSignificant differences $(\mathrm{p} \leq 0.05)$ are shaded. 
Table 11. Number of samples that exceeded chronic iron water-quality standards in the upper Arkansas River, April 1990-March 1993

$[--$, no standard available $]$

\begin{tabular}{|c|c|c|c|}
\hline \multirow[b]{2}{*}{$\begin{array}{c}\text { Site name } \\
\text { (see table 1) }\end{array}$} & \multirow[b]{2}{*}{$\begin{array}{l}\text { Number of } \\
\text { samples } \\
\text { analyzed }\end{array}$} & \multicolumn{2}{|c|}{ Number of samples that exceeded standard ${ }^{\top}$} \\
\hline & & $\begin{array}{c}\text { Chronic } \\
\text { standard for } \\
\text { dissolved iron }\end{array}$ & $\begin{array}{c}\text { Chronic } \\
\text { standard for } \\
\text { total-recoverable iron }\end{array}$ \\
\hline Leadville & 28 & -- & 2 \\
\hline Malta & 26 & -- & 4 \\
\hline Granite & 27 & 2 & 3 \\
\hline Buena Vista & 28 & 0 & 3 \\
\hline Nathrop & 27 & 0 & 5 \\
\hline Wellsville & 27 & 0 & 7 \\
\hline Parkdale & 27 & 0 & 8 \\
\hline Portland & 26 & 0 & $11^{4}$ \\
\hline
\end{tabular}

Colorado Department of Health, 1994.

${ }^{2} 300$ micrograms per liter.

${ }^{3}$ Unless noted: Chronic standard $=1,000$ micrograms per liter.

${ }^{4} 1,200$ micrograms per liter.

\section{Lead}

Dissolved-lead concentrations in the upper Arkansas River exhibited very different spatial and temporal variability patterns compared to the other trace elements of concern (fig. 11). Median dissolvedlead concentrations typically were largest during snowmelt runoff; the largest median concentrations were at Malta $(1.1 \mu \mathrm{g} / \mathrm{L})$ and at Nathrop $(1.0 \mu \mathrm{g} / \mathrm{L})$ (fig. 11). Moore and Ramamoorthy (1984) reported that the dissolved-lead concentrations in unpolluted freshwater typically are less than $3 \mu \mathrm{g} / \mathrm{L}$. During early snowmelt and snowmelt runoff, dissolved-lead concentrations increased substantially between Leadville and Malta. During snowmelt runoff and post-snowmelt runoff, concentrations increased substantially between Buena Vista and Nathrop (fig. 11). Downstream from Leadville, concentrations of dissolved lead were affected minimally by changes in the partitioning of lead between the dissolved and particulate phases; the dissolved-lead fraction remained relatively constant ( 5 to 15 percent) throughout most of the upper basin (fig. 12). Totalrecoverable lead concentrations were largest during snowmelt runoff, and the maximum median concentration $(51 \mu \mathrm{g} / \mathrm{L})$ occurred at Nathrop (fig. 11). There was little variability between total-recoverable lead concentrations during the other three flow regimes; concentrations were much smaller than during snowmelt runoff (fig. 11). The elevated concentrations of dissolved and total-recoverable lead at Malta (fig. 11) are probably attributable to mine drainage, primarily from California Gulch. The elevated lead concentrations at Nathrop cannot be accounted for by inflow from the two major tributaries in the reach, Cottonwood Creek and Chalk Creek (pl. 1) because their concentrations were generally less than those in the main stem of the river (Dash and Ortiz, 1996). Resuspension of lead-enriched fluvial sediment and nonpoint-source contributions are possible sources of the elevated lead concentrations at Nathrop.

An analysis of instantaneous lead loads indicates that the only tributaries that contributed a substantial lead load to the main-stem river throughout the study period were California Gulch in reach 1 and Lake Creek in reach 2 (table 12). Lead loading from California Gulch was solely a function of extremely elevated lead concentrations in California Gulch (Dash and Ortiz, 1996). Streamflow typically was less than $2 \mathrm{ft}^{3} / \mathrm{s}$, but the median total-recoverable lead concentration was $125 \mu \mathrm{g} / \mathrm{L}$ (Dash and Ortiz, 1996).

Pre-treatment and post-treatment dissolvedlead concentrations at the two mine-drainage sites were not tested with the Wilcoxon rank-sum test because more than 50 percent of the data were less than the reporting level. The median total-recoverable lead concentration at the LMDT decreased significantly from $7 \mu \mathrm{g} / \mathrm{L}$ to less than $1 \mu \mathrm{g} / \mathrm{L}$ (table 13 ). However, lead concentrations in the pre-treatment and post-treatment periods were not statistically different at most main-stem Arkansas River sites (table 13). 

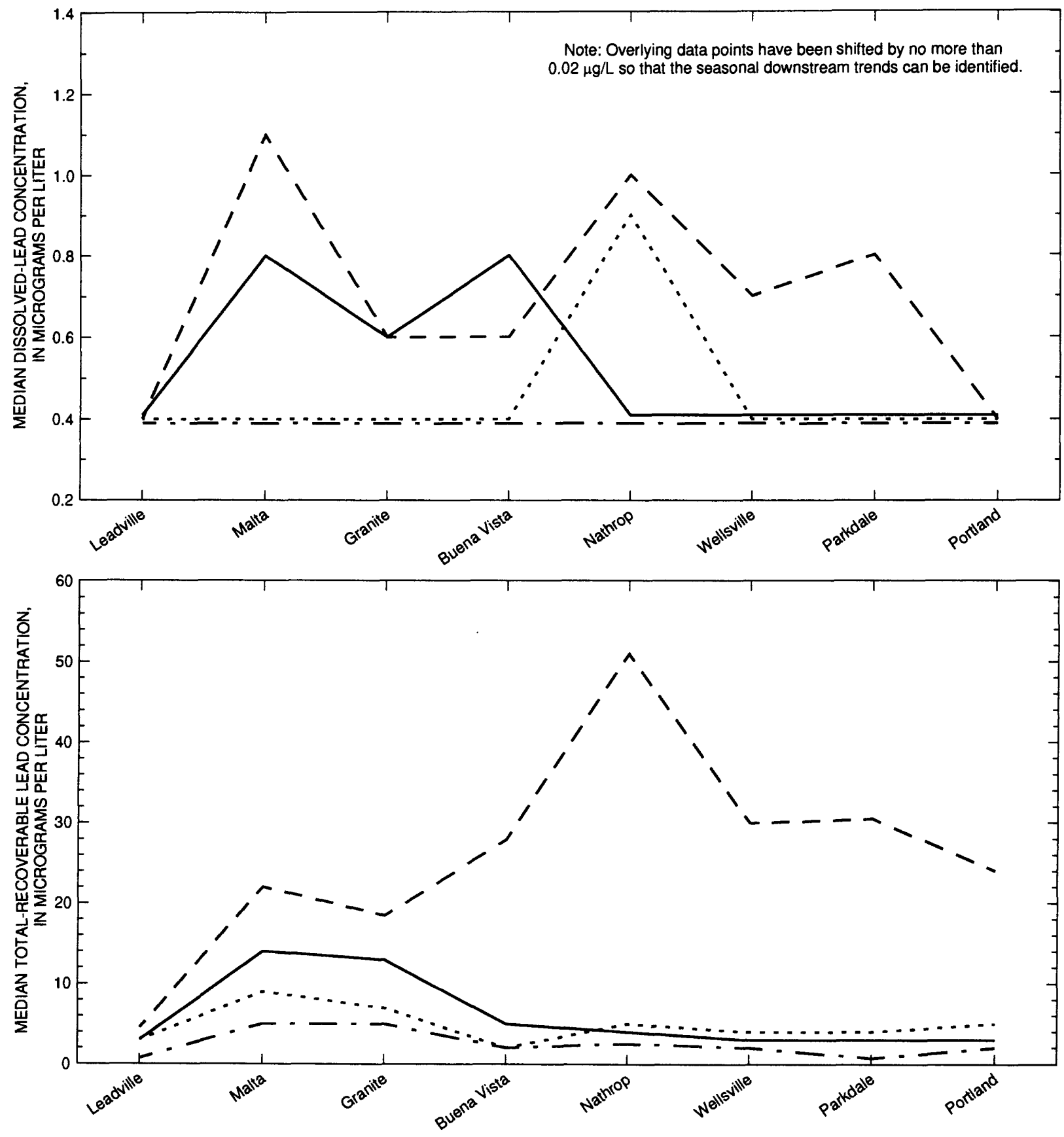

EXPLANATION

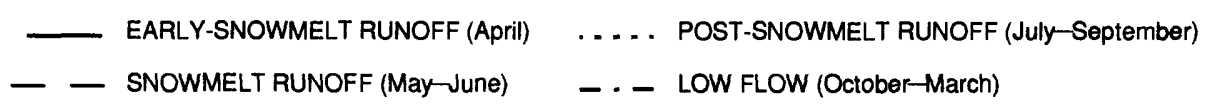

Figure 11. Median dissolved- and total-recoverable lead concentrations by streamflow regime in the upper Arkansas River, April 1990-March 1993. 


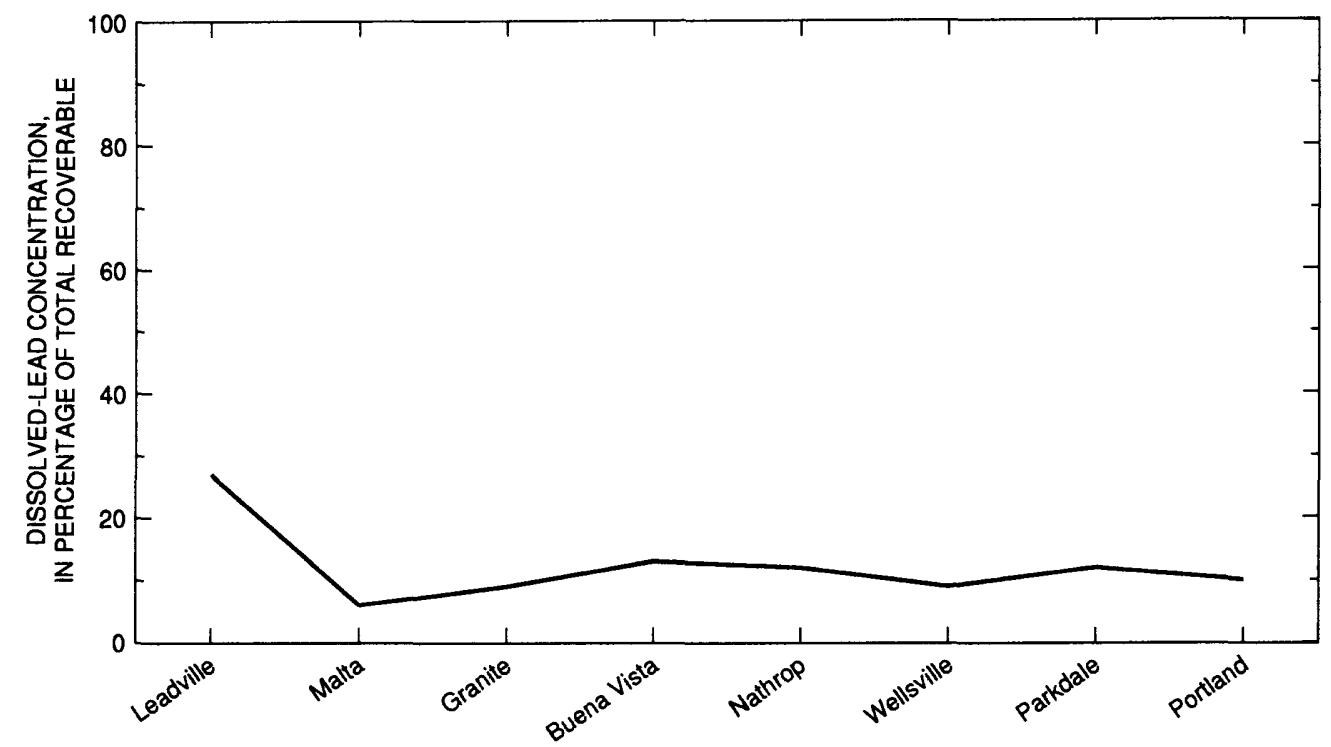

Figure 12. Median percentages of dissolved lead in percentage of total-recoverable lead concentrations in the upper Arkansas River, April 1990-March 1993.

Table 12. Average percentages of instantaneous streamflow and instantaneous total-recoverable lead load contributed to the Arkansas River by the upstream main-stem site and the intervening tributaries in the same reach, April 1990-March 1993

[Main-stem sites are in capital letters; --, insufficient data]

\begin{tabular}{|c|c|c|c|c|c|c|c|c|}
\hline \multirow{2}{*}{$\begin{array}{l}\text { Site name } \\
\text { (see table 1) }\end{array}$} & \multicolumn{4}{|c|}{$\begin{array}{l}\text { Streamflow } \\
\text { (in percent) }\end{array}$} & \multicolumn{4}{|c|}{$\begin{array}{l}\text { Total-recoverable lead load } \\
\text { (in percent) }\end{array}$} \\
\hline & April & June & $\begin{array}{l}\text { July- } \\
\text { August }\end{array}$ & October & April & June & $\begin{array}{l}\text { July- } \\
\text { August }\end{array}$ & October \\
\hline & \multicolumn{8}{|c|}{ Main-stem reach 1 (Leadville to Malta) } \\
\hline LEADVILLE & 41 & 70 & 54 & 30 & 6 & 46 & 46 & 7 \\
\hline California Gulch & 2 & 1 & 2 & 1 & 79 & 4 & 83 & 25 \\
\hline Lake Fork above Halfmoon Creek & 39 & 21 & 36 & 35 & 4 & 5 & 8 & 18 \\
\hline Iowa Gulch & 0 & 4 & 4 & 4 & -- & 8 & 5 & 1 \\
\hline \multirow[t]{2}{*}{ Empire Gulch } & 0 & 2 & 1 & 0 & -- & 1 & 2 & - \\
\hline & \multicolumn{8}{|c|}{ Main-stem reach 2 (Malta to Granite) } \\
\hline MALTA & 56 & 32 & 30 & 80 & 49 & 32 & 48 & 99 \\
\hline \multirow[t]{2}{*}{ Lake Creek below Twin Lakes Reservoir } & 19 & 59 & 56 & 12 & -- & 69 & 28 & -- \\
\hline & \multicolumn{8}{|c|}{ Main-stem reach 3 (Granite to Buena Vista) } \\
\hline GRANITE & 76 & 78 & 78 & 76 & 214 & 63 & 271 & 224 \\
\hline \multirow[t]{2}{*}{ Clear Creek below Clear Creek Reservoir } & 9 & 12 & 15 & 10 & 3 & 2 & 45 & 8 \\
\hline & \multicolumn{8}{|c|}{ Main-stem reach 4 (Buena Vista to Nathrop) } \\
\hline BUENA VISTA & 78 & 92 & 80 & 53 & 112 & 94 & 80 & 86 \\
\hline Cottonwood Creek & 2 & 1 & 1 & 7 & 2 & 0 & 0 & -- \\
\hline \multirow[t]{2}{*}{ Chalk Creek } & 1 & 9 & 8 & 8 & 1 & 6 & 7 & 4 \\
\hline & \multicolumn{8}{|c|}{ Main-stem reach 5 (Nathrop to Wellsville) } \\
\hline NATHROP & 99 & 99 & 96 & 77 & 130 & 124 & 298 & -- \\
\hline \multirow[t]{2}{*}{ South Fork Arkansas River } & 2 & 3 & 1 & 5 & 1 & 1 & 2 & -- \\
\hline & \multicolumn{8}{|c|}{ Main-stem reach 6 (Wellsville to Parkdale) } \\
\hline WELLSVILLE & 83 & 88 & 95 & 87 & 90 & 164 & 72 & 205 \\
\hline Badger Creek & 3 & 0 & 1 & 2 & 3 & 0 & 1 & -- \\
\hline \multirow[t]{2}{*}{ Tallahassee Creek } & 0 & 1 & 0 & 1 & 0 & 0 & 0 & -- \\
\hline & \multicolumn{8}{|c|}{ Main-stem reach 7 (Parkdale to Portland) } \\
\hline PARKDALE & 11 & 98 & 122 & 104 & 107 & 78 & 164 & -- \\
\hline Fourmile Creek & 11 & 2 & 5 & 6 & 22 & 2 & 8 & -- \\
\hline
\end{tabular}


Table 13. Results of Wilcoxon rank-sum test (1-tailed) of pre-treatment (April 1990-March 1992) and post-treatment (April 1992-March 1993) instantaneous streamflow and lead concentrations at selected sites in the upper Arkansas River Basin

[ $\mathrm{ft}^{3} / \mathrm{s}$, cubic feet per second; $\mu \mathrm{g} / \mathrm{L}$, micrograms per liter; --, test could not be performed; NA, not applicable; $<$, less than; $\leq$, less than or equal to]

\begin{tabular}{|c|c|c|c|c|c|c|}
\hline \multirow[b]{2}{*}{$\begin{array}{c}\text { Site name } \\
\text { (see table 1) }\end{array}$} & \multicolumn{2}{|c|}{ Streamflow } & \multicolumn{2}{|c|}{ Dissolved lead } & \multicolumn{2}{|c|}{ Total-recoverable lead } \\
\hline & $\begin{array}{c}\text { Pre-/post- } \\
\text { treatment } \\
\text { median } 1 \\
\left(\mathrm{ft}^{3} / \mathrm{s}\right)\end{array}$ & p-value & $\begin{array}{c}\text { Pre-/post- } \\
\text { treatment } \\
\text { median }{ }^{1} \\
(\mu \mathrm{g} / \mathrm{L})\end{array}$ & p-value & $\begin{array}{c}\text { Pre-/post- } \\
\text { treatment } \\
\text { medlan }{ }^{1} \\
(\mu g / L)\end{array}$ & p-value \\
\hline Leadville Mine Drainage Tunnel & $2.3 / 2.4$ & 0.38 & $--^{2}$ & NA & TYर & $<0.01$ \\
\hline California Gulch & $1.8 / 1.8$ & .50 &.$-^{2}$ & NA & $104 / 135$ & .42 \\
\hline Leadville & $70 / 58$ & .50 &.$-^{2}$ & NA & $3 / 1$ & .13 \\
\hline Malta & $99 / 134$ & .35 & $--^{2}$ & NA & $11 / 8$ & .42 \\
\hline Granite & $277 / 470$ & .45 &.$^{2}$ & NA & $7.5 / 7$ & .44 \\
\hline Buena Vista & $400 / 462$ & .45 &.$-^{2}$ & NA & $7 / 2$ & .18 \\
\hline Nathrop & $563 / 717$ & .45 & $--^{2}$ & NA & 973 & .04 \\
\hline Wellsville & $524 / 742$ & .38 & $--^{2}$ & NA & $4.5 / 2$ & .20 \\
\hline Parkdale & $582 / 843$ & .41 & $--^{2}$ & NA & $3.5 / 3$ & .41 \\
\hline Portland & $512 / 800$ & .18 & $-^{2}$ & NA & $4 / 6$ & .22 \\
\hline
\end{tabular}

${ }^{1}$ Significant differences $(\mathrm{p} \leq 0.05)$ are shaded.

2 Test not performed because more than 50 percent of the data were less than the reporting level.

Water-quality standards for lead were exceeded in a small number of samples at five sites in the upper basin (table 14). The acute standard was exceeded in only one sample that was collected at Nathrop during the snowmelt-runoff regime in 1990. The chronic standard for lead was exceeded in a few samples that were collected at Leadville, Malta, Granite, Buena Vista, and Nathrop. The largest number of chronic exceedances (four) occurred at Nathrop (table 14). Ninety-two percent of the chronic exceedances occurred during the mine-drainage pre-treatment period. Eighty-three percent of the chronic exceedances occurred during the snowmelt-runoff regime.

Table 14. Number of samples that exceeded acute and chronic lead water-quality standards in the upper Arkansas River, April 1990-March 1993

\begin{tabular}{|c|c|c|c|}
\hline \multirow{2}{*}{$\begin{array}{l}\text { Site name } \\
\text { (see table 1) }\end{array}$} & \multirow{2}{*}{$\begin{array}{l}\text { Number of } \\
\text { samples } \\
\text { analyzed }\end{array}$} & \multicolumn{2}{|c|}{ Number of samples that exceeded standard } \\
\hline & & $\begin{array}{c}\text { Acute } \\
\text { standard }\end{array}$ & $\begin{array}{c}\text { Chronic } \\
\text { standard }\end{array}$ \\
\hline Leadville & 27 & 0 & 2 \\
\hline Malta & 26 & 0 & 1 \\
\hline Granite & 27 & 0 & 3 \\
\hline Buena Vista & 27 & 0 & 2 \\
\hline Nathrop & 27 & 1 & 4 \\
\hline Wellsville & 27 & 0 & 0 \\
\hline Parkdale & 27 & 0 & 0 \\
\hline Portland & 26 & 0 & 0 \\
\hline
\end{tabular}




\section{Manganese}

Dissolved-manganese concentrations were largest during the early-snowmelt-runoff streamflow regime; the maximum median concentration of $280 \mu \mathrm{g} / \mathrm{L}$ occurred at Malta (fig. 13). Dissolved- manganese concentrations were largest in the earlysnowmelt-runoff regime probably because, in April, early snowmelt flushed the mines and mine tailings. Additionally, there was relatively little sediment in the water column for the manganese to sorb onto and
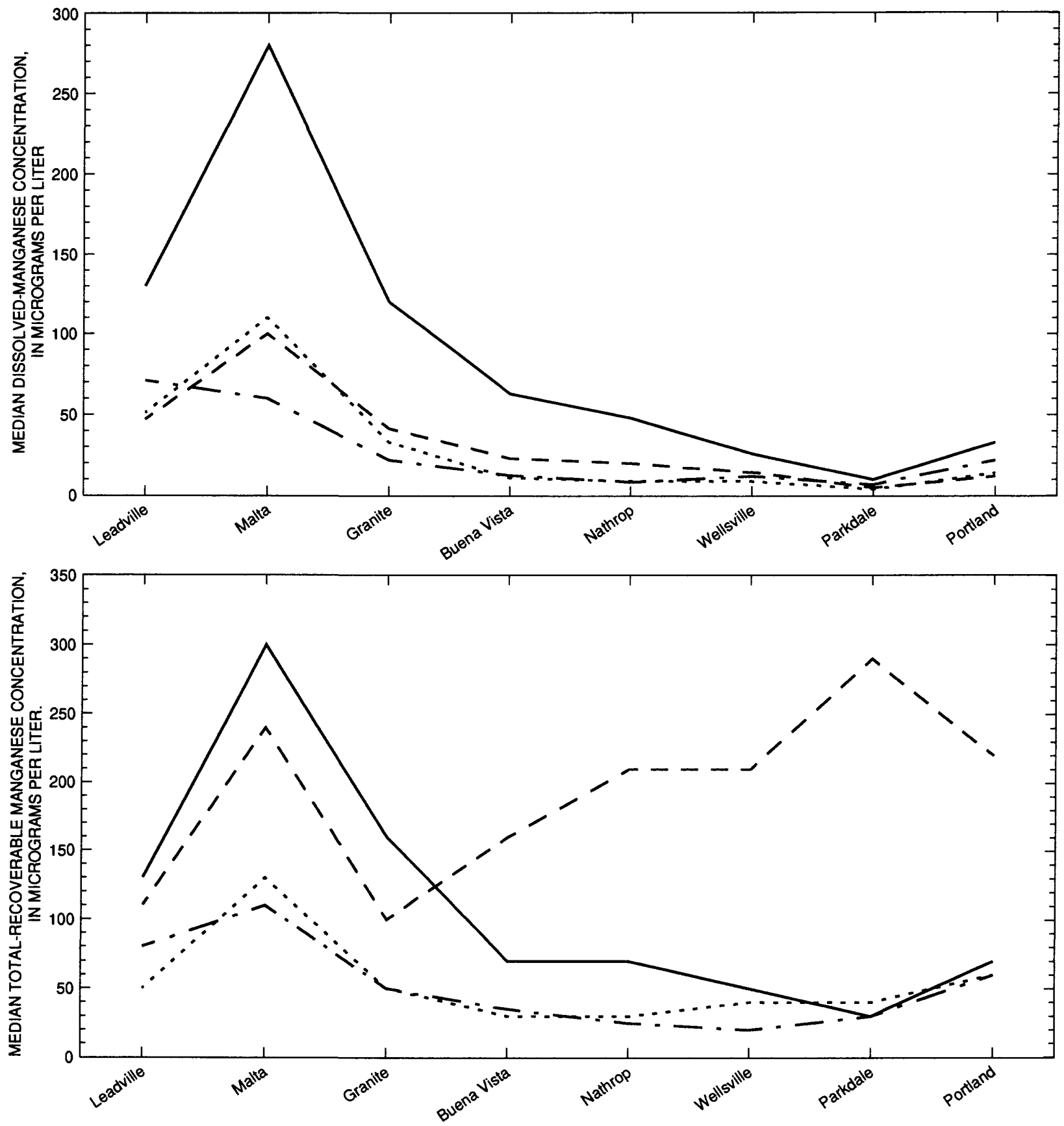

EXPLANATION

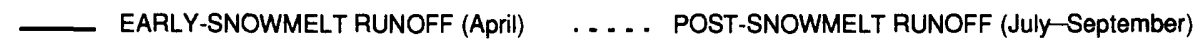

- - SNOWMELT RUNOFF (May_June) _ - - LOW FLOW (October-March)

Figure 13. Median dissolved- and total-recoverable manganese concentrations by streamflow regime in the upper Arkansas River, April 1990-March 1993. 
relatively little streamflow for dilution (Dash and Ortiz, 1996). During the other three flow regimes, dissolved-manganese concentrations were much smaller, and they were not substantially different from one another (fig. 13). Dissolved-manganese concentrations showed consistent increases for all streamflow regimes between Leadville and Malta, probably due to mine drainage from California Gulch, before decreasing downstream from Malta (fig. 13) largely because of increased partitioning of manganese to the particulate phase (fig. 14). Upstream from Buena Vista, total-recoverable manganese concentrations typically were largest during early-snowmelt runoff; therefore, the largest median total-recoverable manganese concentrations in the upper basin coincided with the timing of the largest median dissolved-manganese concentrations (fig. 13). Downstream from Granite, total-recoverable manganese concentrations were largest during snowmelt runoff. In the reach between Leadville and Granite, most of the total-recoverable manganese occurred in the dissolved phase (fig. 14). Concentrations of total-recoverable manganese decreased between Malta and Granite, probably because of dilution by Lake Creek and deposition of particulate manganese. Downstream from Granite, a larger percentage of manganese existed in the particulate phase than in the dissolved phase (fig. 14). Therefore, downstream from Granite, total-recoverable manganese concentrations might have been affected by deposition during much of the year and by resuspension during the elevated streamflow of snowmelt runoff (May-June). Manganese loading from tributaries, with the exception of California Gulch, Lake Fork above Halfmoon Creek, and Lake Creek, generally was insubstantial $(<10$ percent) compared to main-stem loads (table 15).

During the mine-drainage post-treatment period, dissolved and total-recoverable manganese concentrations decreased significantly at the LMDT, California Gulch, and Leadville (table 16). Dissolved-manganese concentrations also decreased significantly at Malta, Granite, Nathrop, and Wellsville during the posttreatment period (table 16).

Water-quality standards for manganese were exceeded in a relatively small number of samples collected at four sites in the upper basin (table 17). The chronic standard for dissolved manganese $(50 \mu \mathrm{g} / \mathrm{L})$ was exceeded in a total of 13 samples that were collected at Granite, Buena Vista, and Nathrop (table 17). Eighty-five percent of the exceedances occurred during the mine-drainage pre-treatment period. About 62 percent of the chronic exceedances occurred during snowmelt runoff, and about 31 percent occurred during early-snowmelt runoff. Only one sample, which was collected at Parkdale following an August thunderstorm, exceeded the chronic standard for total-recoverable manganese $(1,000 \mu \mathrm{g} / \mathrm{L})$ (table 17).

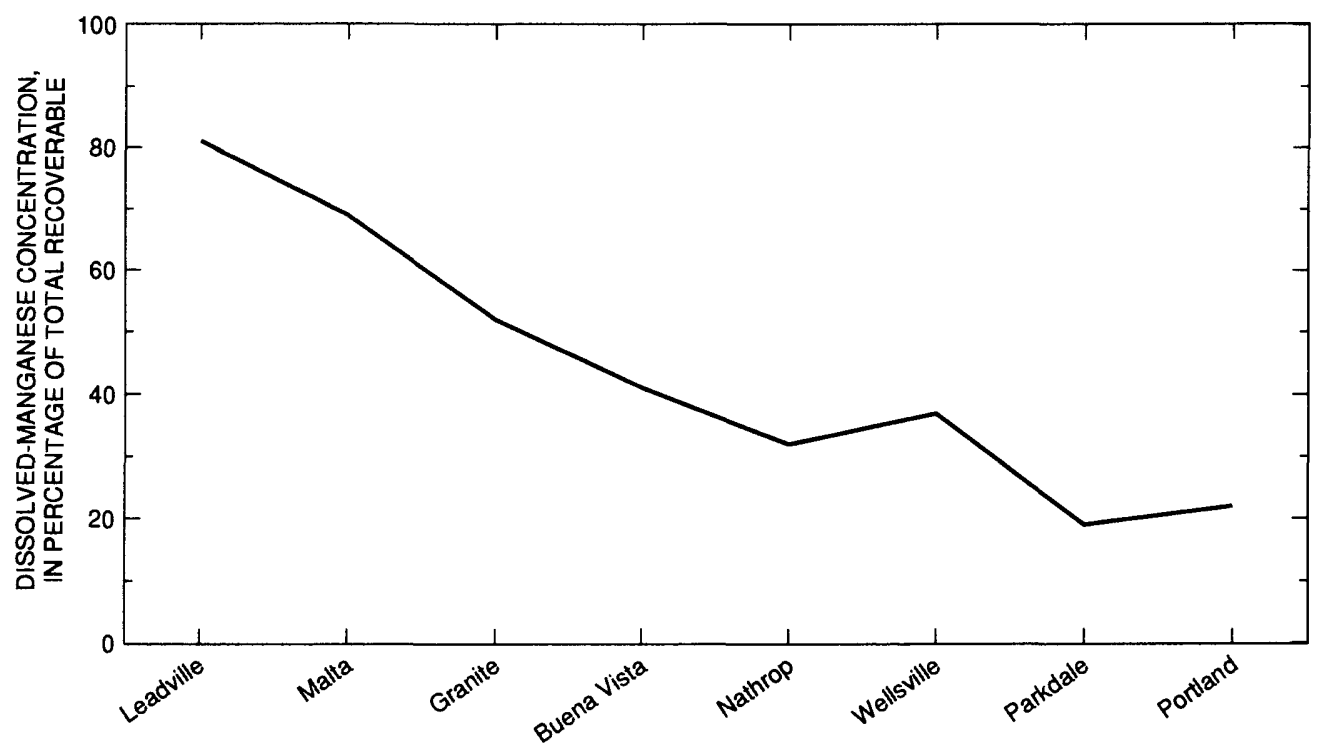

Figure 14. Median percentages of dissolved manganese in percentage of total-recoverable manganese concentrations in the upper Arkansas River, April 1990-March 1993. 
Table 15. Average percentages of instantaneous streamflow and instantaneous total-recoverable manganese load contributed to the Arkansas River by the upstream main-stem site and the intervening tributaries in the same reach, April 1990-March 1993

[Main-stem sites are in capital letters; --, no data]

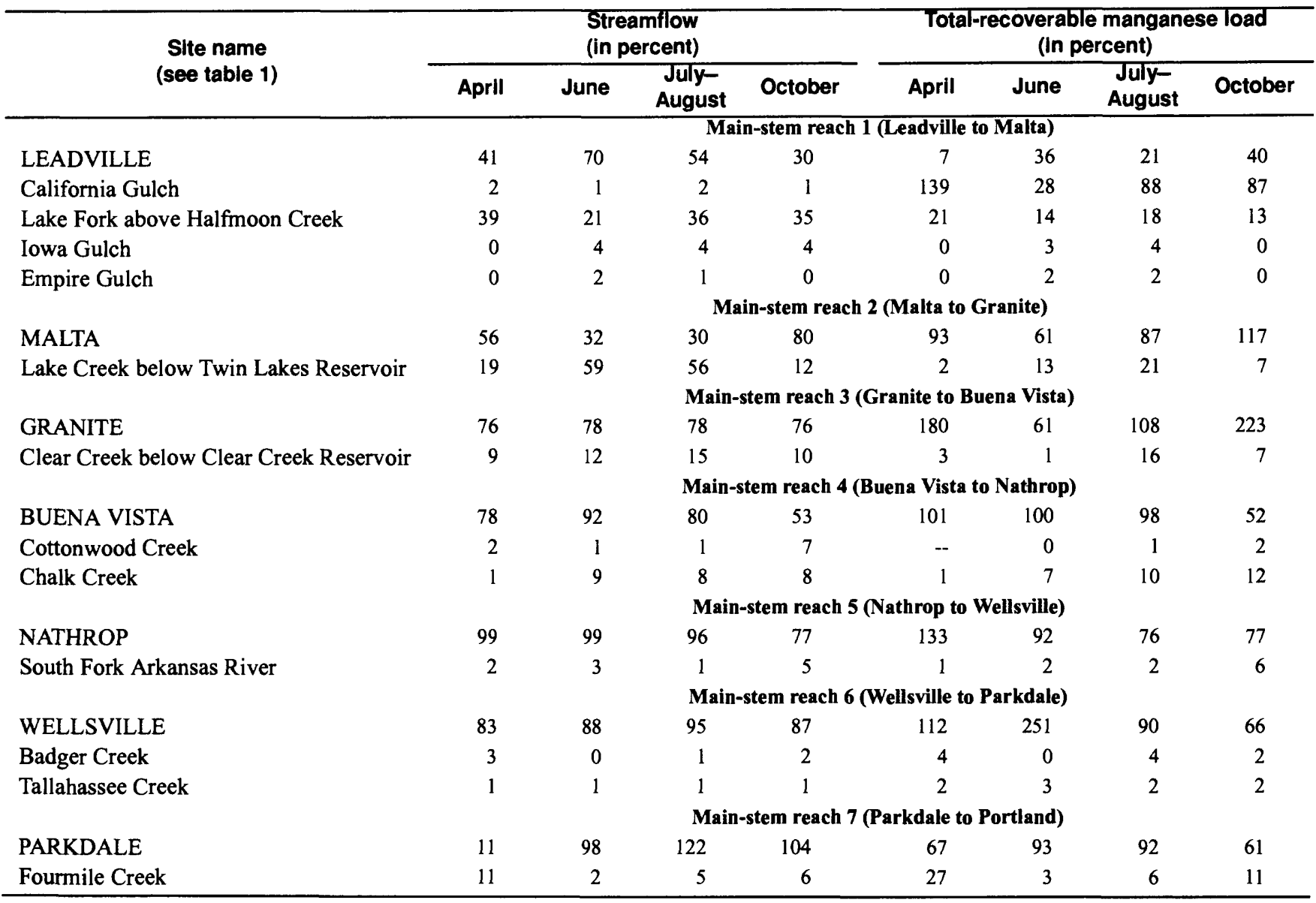

Table 16. Results of Wilcoxon rank-sum test (1-tailed) of pre-treatment (April 1990-March 1992) and post-treatment (April 1992-March 1993) instantaneous streamflow and manganese concentrations at selected sites in the upper Arkansas River Basin

$\left[\mathrm{ft}^{3} / \mathrm{s}\right.$, cubic feet per second; $\mu \mathrm{g} / \mathrm{L}$, micrograms per liter; $<$, less than; $\leq$, less than or equal to]

\begin{tabular}{|c|c|c|c|c|c|c|}
\hline \multirow[b]{2}{*}{$\begin{array}{l}\text { Site name } \\
\text { (see table 1) }\end{array}$} & \multicolumn{2}{|c|}{ Streamflow } & \multicolumn{2}{|c|}{ Dissolved manganese } & \multicolumn{2}{|c|}{$\begin{array}{c}\text { Total-recoverable } \\
\text { manganese }\end{array}$} \\
\hline & $\begin{array}{c}\text { Pre-/post- } \\
\text { treatment } \\
\text { medlan } \\
\left(\mathrm{ft}^{3} / \mathrm{s}\right)\end{array}$ & p-value & $\begin{array}{c}\text { Pre-/post- } \\
\text { treatment } \\
\text { medlan }{ }^{1} \\
(\mu \mathrm{g} / \mathrm{L})\end{array}$ & p-value & $\begin{array}{c}\text { Pre-/post- } \\
\text { treatment } \\
\text { medlan }{ }^{1} \\
(\mu \mathrm{g} / \mathrm{L})\end{array}$ & p-value \\
\hline Leadville Mine Drainage Tunnel & $2.3 / 2.4$ & 0.38 & 15002010 & 0.01 & $6600 / 185$ & $<0.01$ \\
\hline California Gulch & $1.8 / 1.8$ & .50 & $100000 / 3.700$ & .01 & 9.55083 .650 & .02 \\
\hline Leadville & $70 / 58$ & .50 & 74/28: & $<.01$ & $95 / 40$ & $<.01$ \\
\hline Malta & $99 / 134$ & .35 & 110660 & .01 & $150 / 140$ & .12 \\
\hline Granite & $277 / 470$ & .45 & 38119 & .03 & $60 / 60$ & .39 \\
\hline Buena Vista & $400 / 462$ & .45 & $14 / 12$ & .09 & $40 / 50$ & .47 \\
\hline Nathrop & $563 / 717$ & .45 & $117:$ & .05 & $60 / 30$ & .28 \\
\hline Wellsville & $524 / 742$ & .38 & 12110 & .01 & $40 / 40$ & .41 \\
\hline Parkdale & $582 / 843$ & .41 & $6 / 5$ & .24 & $40 / 40$ & .28 \\
\hline Portland & $512 / 800$ & .18 & $17 / 17$ & .34 & $70 / 90$ & .08 \\
\hline
\end{tabular}

${ }^{1}$ Significant differences $(\mathrm{p} \leq 0.05)$ are shaded. 
Table 17. Number of samples that exceeded chronic manganese water-quality standards in the upper Arkansas River, April 1990-March 1993

$[--$, no standard available $]$

\begin{tabular}{|c|c|c|c|}
\hline \multirow[b]{2}{*}{$\begin{array}{l}\text { Site name } \\
\text { (see table 1) }\end{array}$} & \multirow[b]{2}{*}{$\begin{array}{c}\text { Number of sampies } \\
\text { analyzed }\end{array}$} & \multicolumn{2}{|c|}{ Number of samples that exceeded standard } \\
\hline & & $\begin{array}{c}\text { Chronic } \\
\text { standard for } \\
\text { dissolved } \\
\text { manganese }\end{array}$ & $\begin{array}{c}\text { Chronic } \\
\text { standard for totai- } \\
\text { recoverable } \\
\text { manganese }\end{array}$ \\
\hline Leadville & 27 & -- & 0 \\
\hline Malta & 26 & -- & 0 \\
\hline Granite & 27 & 7 & 0 \\
\hline Buena Vista & 27 & 4 & 0 \\
\hline Nathrop & 27 & 2 & 0 \\
\hline Wellsville & 27 & 0 & 0 \\
\hline Parkdale & 27 & 0 & 1 \\
\hline Portland & 26 & 0 & 0 \\
\hline
\end{tabular}

${ }^{\mathrm{l} C}$ Colorado Department of Health, 1994.

${ }^{2}$ Unless noted: Chronic standard $=50$ micrograms per liter.

${ }^{3} 1,000$ micrograms per liter.

\section{Zinc}

Zinc concentrations (fig. 15) showed spatial and temporal patterns similar to manganese (fig. 13). Median dissolved-zinc concentrations typically were largest during early-snowmelt runoff. The concentration of dissolved zinc in unpolluted freshwater typically ranges from 0.5 to $15 \mu \mathrm{g} / \mathrm{L}$ (Moore and Ramamoorthy, 1984). The maximum median concentration $(320 \mu \mathrm{g} / \mathrm{L})$ was at Malta; downstream from Malta, dissolved-zinc concentrations decreased, probably because of increased partitioning to the particulate phase. The percentage of zinc in the dissolved phase decreased from about 83 percent at Leadville to about 19 percent at Portland (fig. 16). Concentrations of dissolved zinc generally increased between Leadville and Malta because of tributary contributions from California Gulch. Total-recoverable zinc concentrations tended to decrease downstream from Malta, except during snowmelt runoff (fig. 15) when resuspension of fluvial sediment by the elevated streamflow probably caused total-recoverable zinc concentrations to increase downstream from Granite. Dilution by Lake Creek and sedimentation of particulate zinc are the probable causes for the substantial decreases in total-recoverable zinc concentrations between Malta and Granite. An analysis of instantaneous total-recoverable zinc loads indicates that the only tributary that contributed a substantial zinc load ( $>10$ percent) to the main-stem river during all streamflow regimes was
California Gulch (table 18). Most other tributaries typically contributed insubstantial loads ( $<10$ percent) compared to the main-stem loads.

Concentrations of dissolved and totalrecoverable zinc had statistically significant decreases $(p \leq 0.05)$ between the pre-treatment and post-treatment periods at both mine-drainage sites and at four of the eight main-stem Arkansas River sites (table 19). With the exception of Parkdale, all main-stem sites had significantly smaller dissolved-zinc concentrations during the post-treatment period (table 19). Total-recoverable zinc concentrations decreased significantly at main-stem sites at Leadville, Malta, Buena Vista, and Wellsville (table 19). Based on these results, it seems likely that the treatment plants had a substantial effect on zinc concentrations.

The acute water-quality standard for dissolved zinc was exceeded in 18 of 28 samples (about 64 percent) collected at Leadville (table 20). Seven of the 18 exceedances occurred during snowmelt runoff, and the other 11 exceedances occurred during the other three flow regimes. Only one of the exceedances occurred after the treatment facility at Leadville Mine Drainage Tunnel began operation. There was no acute standard for zinc at sites located between Leadville and Portland. The chronic stream-water-quality standard for zinc was exceeded in three samples, or less than 2 percent of the main-stem samples collected during the study period (table 20). 

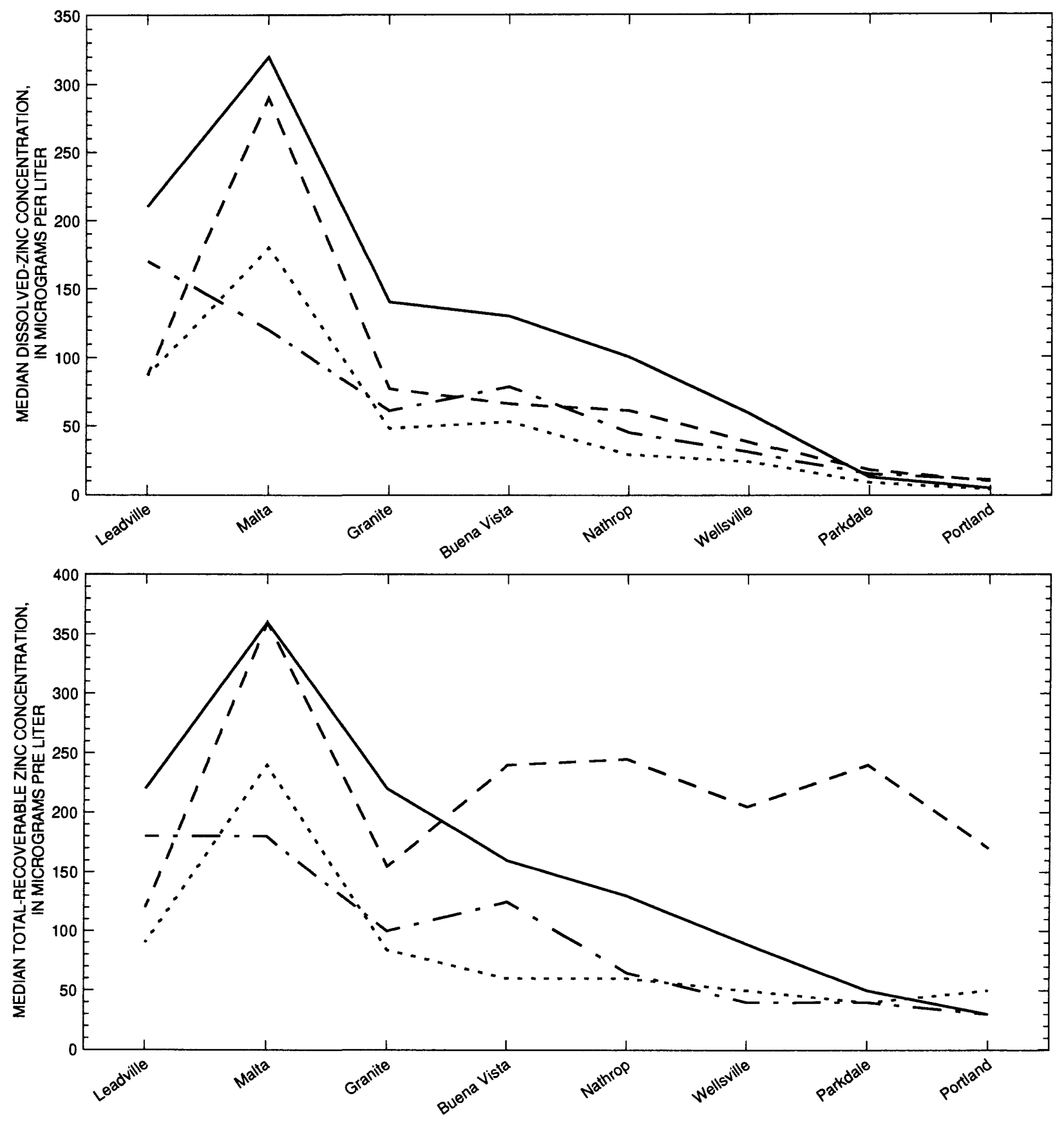

EXPLANATION

$$
\begin{aligned}
& \text { EARLY-SNOWMELT RUNOFF (April) } \\
& \text { — - . . . SNOWO POST-SNOWMELT RUNOFF (July-September) }
\end{aligned}
$$

Figure 15. Median dissolved-and total-recoverable zinc concentrations by streamflow regime in the upper Arkansas River, April 1990-March 1993. 


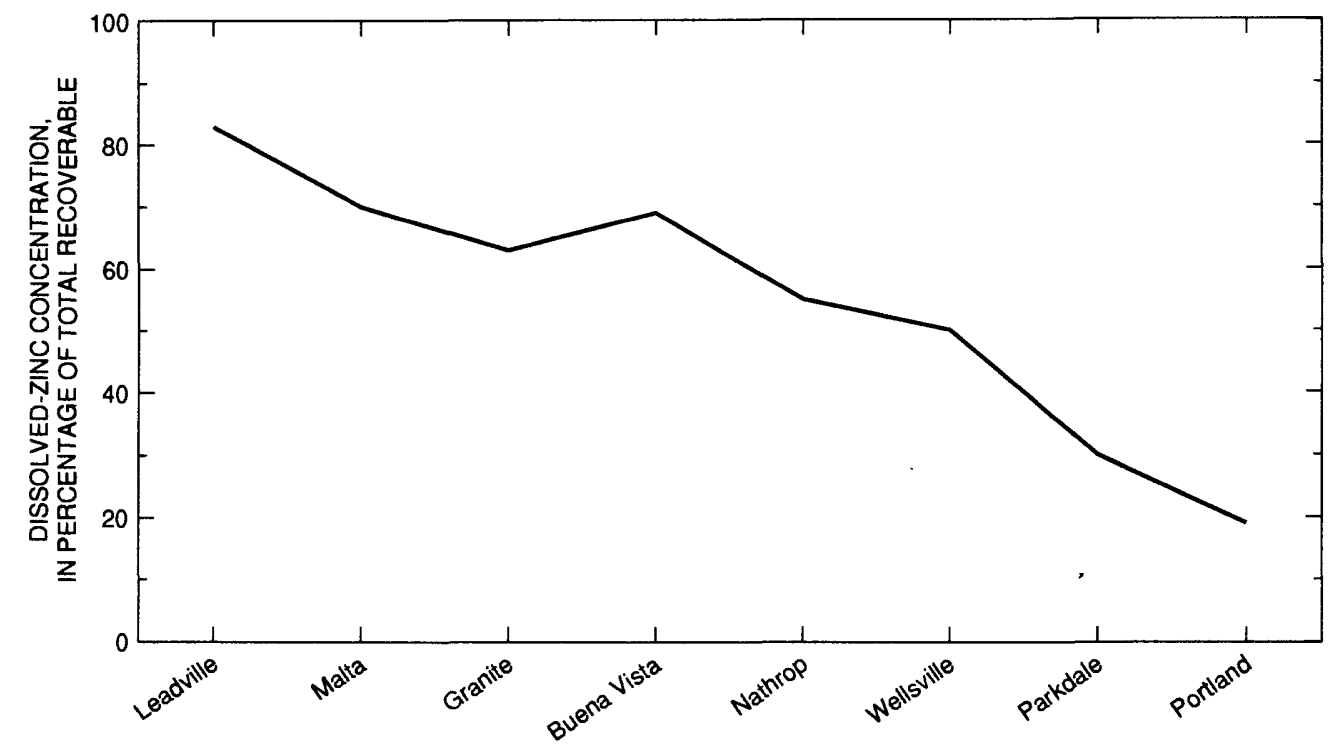

Figure 16. Median percentages of dissolved zinc in percentage of total-recoverable zinc concentrations in the upper Arkansas River, April 1990-March 1993.

Table 18. Average percentages of instantaneous streamflow and instantaneous total-recoverable zinc load contributed to the Arkansas River by the upstream main-stem site and the intervening tributaries in the same reach, April 1990-March 1993

[Main-stem sites are in capital letters; --, insufficient data]

\begin{tabular}{|c|c|c|c|c|c|c|c|c|}
\hline $\begin{array}{c}\text { Site name } \\
\text { (see table 1) }\end{array}$ & \multicolumn{4}{|c|}{$\begin{array}{l}\text { Streamflow } \\
\text { (in percent) }\end{array}$} & \multicolumn{4}{|c|}{$\begin{array}{l}\text { Total-recoverable zinc load } \\
\text { (in percent) }\end{array}$} \\
\hline LEADVILLE & 41 & 70 & 54 & 30 & 7 & 30 & 16 & 28 \\
\hline California Gulch & 2 & 1 & 2 & 1 & 116 & 32 & 78 & 99 \\
\hline Lake Fork above Halfmoon Creek & 39 & 21 & 36 & 35 & 8 & 2 & 2 & -- \\
\hline \multirow[t]{2}{*}{ Empire Gulch } & 0 & 2 & 1 & 0 & -- & 0 & 0 & - \\
\hline & \multicolumn{8}{|c|}{ Main-stem reach 2 (Malta to Granite) } \\
\hline MALTA & 56 & 32 & 30 & 80 & 83 & 78 & 72 & 99 \\
\hline \multirow[t]{2}{*}{ Lake Creek below Twin Lakes Reservoir } & 19 & 59 & 56 & 12 & -- & -- & 4 & -- \\
\hline & \multicolumn{8}{|c|}{ Main-stem reach 3 (Granite to Buena Vista) } \\
\hline GRANITE & 76 & 78 & 78 & 76 & 118 & 54 & 457 & 80 \\
\hline Cottonwood Creek & 2 & 1 & 1 & 7 & 0 & -- & 1 & -- \\
\hline \multirow[t]{2}{*}{ Chalk Creek } & 1 & 9 & 8 & 8 & 0 & 8 & 5 & - \\
\hline & \multicolumn{8}{|c|}{ Main-stem reach 5 (Nathrop to Wellsville) } \\
\hline NATHROP & 99 & 99 & 96 & 77 & 178 & 105 & 274 & 120 \\
\hline \multirow[t]{2}{*}{ South Fork Arkansas River } & 2 & 3 & 1 & 5 & -- & 1 & -- & -- \\
\hline & \multicolumn{8}{|c|}{ Main-stem reach 6 (Wellsville to Parkdale) } \\
\hline WELLSVILLE & 83 & 88 & 95 & 87 & 142 & 324 & 128 & 132 \\
\hline Badger Creek & 3 & 0 & 1 & 2 & 1 & -- & -- & -- \\
\hline \multirow[t]{2}{*}{ Tallahassee Creek } & 0 & 1 & 0 & 1 & 0 & -- & 0 & -- \\
\hline & \multicolumn{8}{|c|}{ Main-stem reach 7 (Parkdale to Portland) } \\
\hline
\end{tabular}


Table 19. Results of Wilcoxon rank-sum test (1-tailed) of pre-treatment (April 1990-March 1992) and post-treatment (April 1992-March 1993) instantaneous streamflow and zinc concentrations at selected sites in the upper Arkansas River Basin

$\left[\mathrm{ft}^{3} / \mathrm{s}\right.$, cubic feet per second; $\mu \mathrm{g} / \mathrm{L}$, micrograms per liter; $<$, less than; $\leq$, less than or equal to]

\begin{tabular}{|c|c|c|c|c|c|c|}
\hline \multirow[b]{2}{*}{$\begin{array}{c}\text { Slte name } \\
\text { (see table 1) }\end{array}$} & \multicolumn{2}{|c|}{ Streamflow } & \multicolumn{2}{|c|}{ Dissolved zinc } & \multicolumn{2}{|c|}{$\begin{array}{l}\text { Total-recoverable } \\
\text { zinc }\end{array}$} \\
\hline & $\begin{array}{c}\text { Pre-/post- } \\
\text { treatment } \\
\text { median } \\
\left(\mathrm{ft}^{3} / \mathrm{s}\right)\end{array}$ & p-value & $\begin{array}{c}\text { Pre-/post- } \\
\text { treatment } \\
\text { median } \\
(\mu \mathrm{g} / L)\end{array}$ & p-value & $\begin{array}{c}\text { Pre-/post- } \\
\text { treatment } \\
\text { median } 1 \\
(\mu g / L)\end{array}$ & p-value \\
\hline Leadville Mine Drainage Tunnel & $2.3 / 2.4$ & 0.38 & $3,600 \% \%$ & 0.01 & 3,60020 & $<0.01$ \\
\hline California Gulch & $1.8 / 1.8$ & .50 & $14,0001,600$ & .02 & $14,0003.550$ & .02 \\
\hline Leadville & $70 / 58$ & .50 & .60224 & $<.01$ & $210 / 40$ & $<.01$ \\
\hline Malta & $99 / 134$ & .35 & 230.110 & .01 & 2901180 & .01 \\
\hline Granite & $277 / 470$ & .45 & 79743 & .02 & $120 / 100$ & .44 \\
\hline Buena Vista & $400 / 462$ & .45 & 85158 & .01 & $100 \% 30$ & .05 \\
\hline Nathrop & $563 / 717$ & .45 & 54730 & .01 & $85 / 80$ & .28 \\
\hline Wellsville & $524 / 742$ & .38 & 4.20 & $<.01$ & 8020 & $<.01$ \\
\hline Parkdale & $582 / 843$ & .41 & $14 / 9$ & .11 & $50 / 50$ & .45 \\
\hline Portland & $512 / 800$ & .18 & $10 \% 4$ & $<.01$ & $40 / 50$ & .20 \\
\hline
\end{tabular}

${ }^{1}$ Significant differences $(\mathrm{p} \leq 0.05)$ are shaded.

Table 20. Number of samples that exceeded acute and chronic zinc water-quality standards in the upper Arkansas River, April 1990-March 1993

$[-$, no standard available $]$

\begin{tabular}{|c|c|c|c|}
\hline \multirow{2}{*}{$\begin{array}{c}\text { Site name } \\
\text { (see table 1) }\end{array}$} & \multirow{2}{*}{$\begin{array}{l}\text { Number of } \\
\text { samples } \\
\text { analyzed }\end{array}$} & \multicolumn{2}{|c|}{ Number of samples that exceeded standard } \\
\hline & & $\begin{array}{c}\text { Acute } \\
\text { standard }\end{array}$ & $\begin{array}{l}\text { Chronic } \\
\text { standard }^{3}\end{array}$ \\
\hline Leadville & 28 & 18 & $1^{4}$ \\
\hline Malta & 26 & -- & $0^{5}$ \\
\hline Granite & 27 & -- & $1^{6}$ \\
\hline Buena Vista & 28 & -- & $0^{6}$ \\
\hline Nathrop & 27 & -- & $1^{6}$ \\
\hline Wellsville & 27 & -- & $0^{6}$ \\
\hline Parkdale & 27 & - & $0^{6}$ \\
\hline Portland & 26 & 0 & 0 \\
\hline
\end{tabular}

${ }^{1}$ Acute and chronic zinc standards are based on dissolved-zinc concentrations (Colorado Department of Health, 1994).

2 Acute standard $=\mathrm{e}^{(0.8473[\ln (\text { hardness })]+0.8604)}$.

${ }^{3}$ Unless noted: Chronic standard $=\mathrm{e}^{(0.8473[\ln \text { (hardness) }]+0.7614)}$.

${ }^{4} 365$ micrograms per liter.

5118 micrograms per liter.

6130 micrograms per liter. 


\section{Secondary Trace Elements}

Most water samples collected in the upper basin were not analyzed for concentrations of the secondary trace elements arsenic, chromium, mercury, nickel, selenium, and silver. The secondary trace elements were assumed to occur at concentrations that would not constitute a water-quality concern. To validate this assumption, water samples from four mainstem Arkansas River sites (Buena Vista, Wellsville, Parkdale, and Portland) were collected five times during the study period and analyzed for concentrations of dissolved and total-recoverable secondary trace elements. These data are reported in Dash and Ortiz (1996).

All samples (20 of 20 ) analyzed for dissolved arsenic and 90 percent (18 of 20) of the samples that were analyzed for total-recoverable arsenic had concentrations that were less than the reporting limit $(1 \mu \mathrm{g} / \mathrm{L})$. One sample collected at Parkdale and one at Portland had total-recoverable arsenic concentrations of $1 \mu \mathrm{g} / \mathrm{L}$. Moore and Ramamoorthy (1984) reported that arsenic concentrations in most unpolluted freshwater are less than $1 \mu \mathrm{g} / \mathrm{L}$. Ninety-five percent (19 of 20 ) of the samples analyzed for dissolved chromium and 70 percent (14 of 20) of the samples analyzed for total-recoverable chromium had concentrations that were less than the reporting limit $(1 \mu \mathrm{g} / \mathrm{L})$. The median concentration of the six samples that contained totalrecoverable chromium concentrations larger than the reporting limit was $1 \mu \mathrm{g} / \mathrm{L}$. In unpolluted lakes and rivers, dissolved-chromium concentrations typically range from 1 to $2 \mu \mathrm{g} / \mathrm{L}$ (Moore and Ramamoorthy, 1984). Ninety-five percent (19 of 20) of the samples that were analyzed for dissolved and total-recoverable mercury had concentrations that were less than the reporting limit $(0.1 \mu \mathrm{g} / \mathrm{L})$. Dissolved and total-recoverable nickel concentrations were less than the reporting limit $(1 \mu \mathrm{g} / \mathrm{L})$ in 60 percent $(12$ of 20$)$ of the samples. The occurrence of nickel concentrations that was larger than the reporting limit increased downstream; the median concentration of those samples was $3.5 \mu \mathrm{g} / \mathrm{L}$. At Portland, 80 percent ( 4 of 5 ) of the total-recoverable nickel concentrations were larger than the reporting limit; the median dissolved-nickel concentration of those four samples was $2.5 \mu \mathrm{g} / \mathrm{L}$. Snodgrass (1980) reported that dissolved-nickel concentrations in unpolluted freshwater usually range from 1 to $3 \mu \mathrm{g} / \mathrm{L}$. About 90 percent of the samples analyzed for total-recoverable and dissolved selenium had concentrations less than the reporting limit $(1 \mu \mathrm{g} / \mathrm{L})$. Concentrations of dissolved and totalrecoverable silver were less than the reporting limit $(1 \mu \mathrm{g} / \mathrm{L})$ in all 20 samples that were collected and analyzed. The analytical reporting limit was too large to indicate if silver occurred at concentrations that might be toxic to aquatic life. Based on these results, arsenic, chromium, mercury, nickel, and selenium do not occur in large enough concentrations to pose a concern for the quality of water in the upper Arkansas River.

\section{Lower Basin}

Trace-element sources in the lower basin include inflow from the mining-affected upper basin, point and nonpoint sources associated with urban land use, irrigation return flows associated with agricultural land use, and tributary inflow. Lewis and Edelmann (1994) reported that a substantial percentage of many trace elements that enter Pueblo Reservoir from the upper basin was removed from the water column between the upper and lower ends of Pueblo Reservoir because of deposition within the reservoir. These findings were based on data collected during 1985-89. Although Lewis and Edelmann (1994) did not measure the release of trace elements from the bottom sediments, periods of prolonged anoxia in Pueblo Reservoir could cause dissolution of substantial quantities of some trace elements from the bottom sediments to the water column, to the reservoir outflow, and eventually to the lower Arkansas River. No periods of prolonged anoxia were measured in the reservoir during 1985-89, and dissolution of sedimented trace elements did not occur.

In the reach downstream from Pueblo Reservoir to Avondale (pl. 1), the trace elements of potential concern include cadmium, chromium, copper, iron, lead, manganese, nickel, selenium, silver, and zinc. These trace elements were selected based on the potential for trace-element transport from the upper basin, urbanized land use in the Pueblo area, use of the Arkansas River for domestic water supplies by the city of Pueblo and the St. Charles Mesa Water Users Association, and tributary inflow from Fountain Creek. The diversion point for the city of Pueblo water supply is located between the main-stem sites Below Pueblo Reservoir and Pueblo (table 1); the diversion point for the St. Charles Mesa Water Users Association water supply during low flow is located at the main-stem 
Pueblo site (table 1). The confluence of the Arkansas River and Fountain Creek is downstream from the main-stem site at Pueblo and just upstream from the main-stem site at Highway 227 (table 1). A substantial percentage of streamflow in Fountain Creek is derived from the city of Colorado Spring's municipal wastewater effluent. Downstream from Avondale to the Colorado-Kansas State line, land use predominantly is agricultural, and the primary trace elements of potential concern are copper, iron, manganese, selenium, and zinc. Secondary trace-elements of potential concern in this reach include cadmium, chromium, lead, and silver, which were analyzed in six samples collected at each of the following Arkansas River main-stem sites: Catlin Dam, Las Animas, and Below John Martin Reservoir (table 1).

Concentrations of some trace elements in the lower Arkansas River have considerable temporal variability because of the variability of streamflow. Water storage and release operations in the two main-stem reservoirs in the lower basin, Pueblo Reservoir and John Martin Reservoir, cause much of the variability in streamflow in the lower Arkansas River. The downstream temporal variability of traceelement concentrations in the lower basin is described in terms of three flow regimes, which are slightly different from those described for the upper basin trace elements. The streamflow regimes in the lower basin are low flow (October-April), snowmelt runoff (May-June), and post-snowmelt runoff (JulySeptember). This definition of streamflow regimes serves as a general guideline for the interpretation of trace-element concentrations and is subject to some degree of variability due to year-to-year variability in weather conditions and reservoir operations.

\section{Cadmium}

Downstream from Pueblo Reservoir to Avondale, dissolved- and total-recoverable cadmium concentrations typically were less than their respective reporting limits, $0.1 \mu \mathrm{g} / \mathrm{L}$ and $1 \mu \mathrm{g} / \mathrm{L}$, during all three flow regimes. Two exceptions were measured during the low-flow regime at the sites Below Pueblo Reservoir and Pueblo; the median dissolved-cadmium concentrations were 0.18 and $0.14 \mu \mathrm{g} / \mathrm{L}$, respectively. Cadmium concentrations were analyzed in six samples collected at each of three main-stem sites from Catlin Dam downstream to Below John Martin Reservoir. At these sites, all dissolved-cadmium concentrations were less than the reporting limit $(1 \mu \mathrm{g} / \mathrm{L})$. Conversely, total-recoverable cadmium concentrations at Catlin Dam and at Las Animas typically were greater than the reporting limit $(1 \mu \mathrm{g} / \mathrm{L})$ and ranged from 1 to $5 \mu \mathrm{g} / \mathrm{L}$. Total-recoverable cadmium concentrations in samples collected at Below John Martin Reservoir were all less than the reporting limit. Only one sample (collected in August 1991 at the site Below Pueblo Reservoir) exceeded the chronic water-quality standard for dissolved cadmium (table 21). No samples exceeded the chronic standard for total-recoverable cadmium (table 21).

Table 21. Number of samples that exceeded chronic cadmium water-quality standards in the lower Arkansas River, April 1990-March 1993

\begin{tabular}{|c|c|c|c|}
\hline \multirow[b]{2}{*}{$\begin{array}{c}\text { Site name } \\
\text { (see table 1) }\end{array}$} & \multirow[b]{2}{*}{$\begin{array}{c}\text { Number of samples } \\
\text { analyzed }\end{array}$} & \multicolumn{2}{|c|}{ Number of samples that exceeded standard } \\
\hline & & $\begin{array}{c}\text { Chronic } \\
\text { standard for } \\
\text { dissolved cadmium }{ }^{2}\end{array}$ & $\begin{array}{l}\text { Chronic standard for } \\
\text { totai-recoverable } \\
\text { cadmium }{ }^{3}\end{array}$ \\
\hline Below Pueblo Reservoir & 26 & 1 & $0^{4}$ \\
\hline Pueblo & 25 & 0 & 0 \\
\hline Highway 227 & 24 & 0 & 0 \\
\hline Avondale & 24 & 0 & 0 \\
\hline Catlin Dam & 6 & 0 & 0 \\
\hline Las Animas & 6 & 0 & 0 \\
\hline Below John Martin Reservoir & 6 & 0 & 0 \\
\hline
\end{tabular}




\section{Chromium}

About 90 percent or more of the samples collected at the four sites from Pueblo Reservoir to Avondale had dissolved-chromium concentrations that were less than the reporting limit of $1 \mu \mathrm{g} / \mathrm{L}$. Totalrecoverable chromium concentrations typically were less than or equal to the reporting limit $(1 \mu \mathrm{g} / \mathrm{L})$ at the main-stem sites, Below Pueblo Reservoir and Pueblo (fig.17). Between Pueblo and Highway 227, the median total-recoverable chromium concentration increased to $1.4 \mu \mathrm{g} / \mathrm{L}$ and $2.0 \mu \mathrm{g} / \mathrm{L}$ during the postsnowmelt runoff and low-flow regimes, respectively (fig. 17). Inflow of chromium from Fountain Creek presumably caused this increase; the median totalrecoverable chromium concentration in Fountain Creek at Pueblo was $6 \mu \mathrm{g} / \mathrm{L}$ (Dash and Ortiz, 1996). The median total-recoverable chromium concentration generally increased between Highway 227 and Avondale (fig. 17); the resuspension of chromium with fluvial sediment and unsampled tributary inflow between Highway 227 and Avondale are possible causes of the increased concentrations.

Dissolved and total-recoverable chromium concentrations were analyzed in six samples collected at three main-stem sites from Catlin Dam downstream to Below John Martin Reservoir. Seventeen of these 18 samples had dissolved-chromium concentrations that were less than the reporting limit $(1 \mu \mathrm{g} / \mathrm{L})$. Conversely, total-recoverable chromium concentrations at Catlin Dam and at Las Animas typically were greater than the reporting limit and ranged from 2 to $170 \mu \mathrm{g} / \mathrm{L}$. It was not possible to distinguish temporal patterns in total-recoverable chromium concentrations at these three sites because of the small number of samples that were collected. The median totalrecoverable concentrations at Catlin Dam and at Las Animas were 16.5 and $11.5 \mu \mathrm{g} / \mathrm{L}$, respectively. Between Las Animas and Below John Martin Reservoir, the median total-recoverable chromium concentration decreased to $0.85 \mu \mathrm{g} / \mathrm{L}$, presumably due to deposition in the reservoir. The resuspension of chromium with fluvial sediment and unsampled tributary inflow are possible causes of increased total-recoverable chromium concentrations at Catlin Dam and at Las Animas. No samples collected at any site in the lower basin had dissolved-chromium concentrations that exceeded water-quality standards.
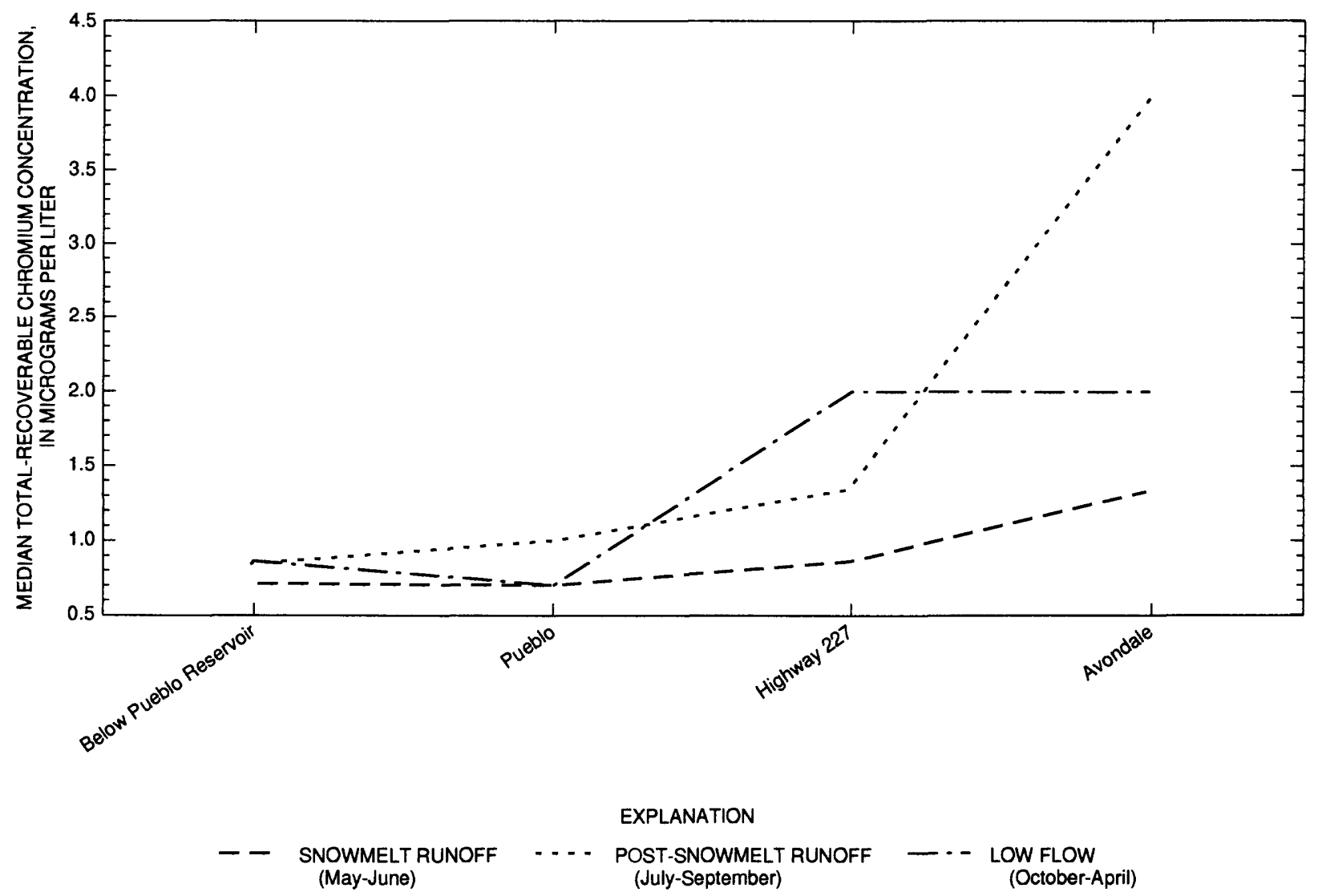

Figure 17. Median total-recoverable chromium concentrations by streamflow regime in the lower Arkansas River, April 1990-March 1993. 


\section{Copper}

A comparison of dissolved-copper concentrations at the farthest downstream site in the upper basin, Portland (fig. 7), and the first site downstream from Pueblo Reservoir, Below Pueblo Reservoir (fig. 18), indicates that dissolved-copper was transported conservatively through the reservoir. Dissolved-copper concentrations in the lower Arkansas River generally were largest during the postsnowmelt runoff regime; the maximum median concentration of $4 \mu \mathrm{g} / \mathrm{L}$ occurred during the postsnowmelt runoff regime at Highway 227 (fig. 18). This substantial increase cannot be accounted for by inflow from Fountain Creek, which typically had concentrations of $2 \mu \mathrm{g} / \mathrm{L}$ (Dash and Ortiz, 1996). Nonpoint sources in the Pueblo area or resuspension of colloidal copper, which would be included in the dissolved fraction, are possible sources for the increase. Downstream from Avondale, dissolvedcopper concentrations typically decreased. Totalrecoverable copper concentrations were largest during the post-snowmelt runoff regime and increased downstream to Catlin Dam; the maximum median totalrecoverable copper concentration $(42 \mu \mathrm{g} / \mathrm{L})$ occurred at Catlin Dam during the post-snowmelt runoff regime (fig. 18). Total-recoverable copper concentrations at Catlin Dam (fig. 18) typically were larger than concentrations at any main-stem site in the upper basin (fig. 7). Resuspension of copper with fluvial sediment and unsampled tributary inflow are likely sources of the elevated total-recoverable copper concentrations at Catlin Dam. Two water samples that were collected during two storm-runoff events from the Apishapa River (pl. 1), which is a tributary to the Arkansas River 2.3 miles upstream from Catlin Dam, had totalrecoverable copper concentrations of $300 \mu \mathrm{g} / \mathrm{L}$ and $260 \mu \mathrm{g} / \mathrm{L}$ (Dash and Ortiz, 1996). These concentrations are 200 to 230 percent larger than the highest instantaneous total-recoverable copper concentration that was measured in any lower Arkansas River sample. Another storm-runoff sample, which was collected from the Purgatoire River just upstream from John Martin Reservoir, had a total-recoverable copper concentration of $200 \mu \mathrm{g} / \mathrm{L}$ (Dash and Ortiz, 1996). Based on these three samples, it seems likely that the tributary inflow to the lower Arkansas River, especially during storm-runoff events, probably represents a major copper source to the lower Arkansas River. Total-recoverable copper concentrations decreased substantially downstream from John Martin Reservoir, possibly because of deposition in the reservoir. Stream water-quality standards for dissolved copper were not exceeded at any site in the lower Arkansas River.

\section{Iron}

A comparison of dissolved-iron concentrations at Portland, the upstream site closest to Pueblo Reservoir (fig. 9), and the site immediately downstream from the reservoir, Below Pueblo Reservoir (fig. 19), indicates nonconservative transport of dissolved iron through Pueblo Reservoir. Deposition within the reservoir is a probable cause of decreased concentrations. Concentrations of dissolved iron generally were similar at all sites downstream from Pueblo Reservoir to Las Animas (fig. 19). During low flow, median dissolved-iron concentrations increased substantially at the site just downstream from John Martin Reservoir; the maximum median concentration of dissolved iron $(15 \mu \mathrm{g} / \mathrm{L})$ occurred at this site. It is suspected that the water in John Martin Reservoir becomes anoxic during the winter; therefore, dissolution of iron from reservoir bottom sediments and release to the water column would be a possible cause of increased dissolved-iron concentrations downstream from the reservoir. Temporally, total-recoverable iron concentrations generally did not vary substantially at any main-stem site downstream to Avondale (fig. 19). Concentrations did, however, increase substantially between Avondale and Las Animas during the snowmelt-runoff and post-snowmelt runoff regimes (fig. 19), presumably because of resuspension and tributary inflow. In the two samples that were collected from the Apishapa River during storm-runoff events, total-recoverable iron concentrations were 270,000 and $180,000 \mu \mathrm{g} / \mathrm{L}$ (Dash and Ortiz, 1996); these concentrations were about 200 to 300 percent larger than the highest instantaneous total-recoverable iron concentration in any lower Arkansas River sample. A storm-runoff sample collected from the Purgatoire River had a total-recoverable iron concentration of $250,000 \mu \mathrm{g} / \mathrm{L}$ (Dash and Ortiz, 1996). These tributary storm-runoff samples indicate that inflow from tributaries, especially during storm events, represents a substantial iron source to the lower Arkansas River. Only one sample collected in the lower Arkansas River had a dissolved-iron concentration that exceeded the chronic water-quality standard for dissolved iron (table 22). Conversely, about 37 percent 

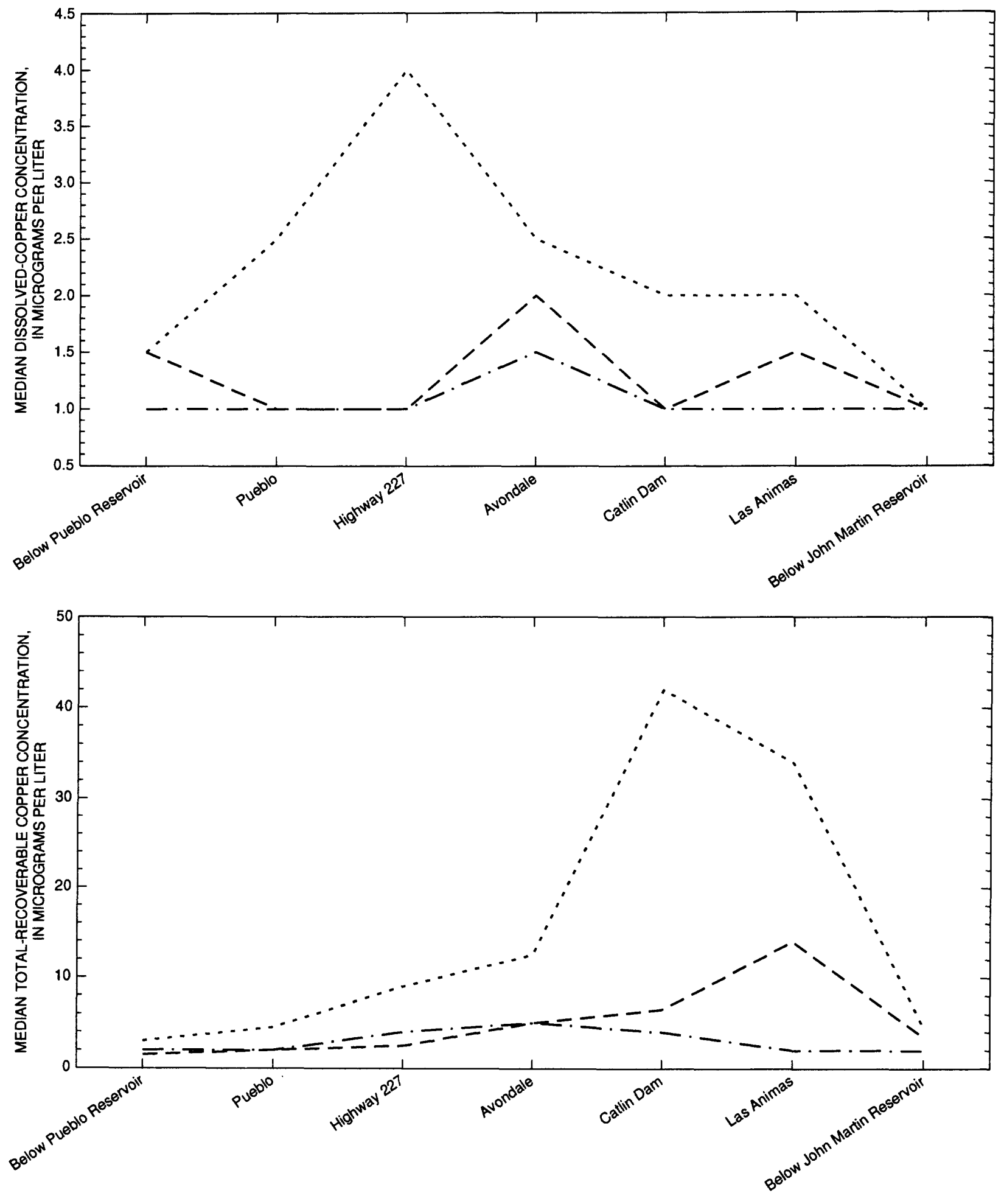

EXPLANATION

- - SNOWMELT RUNOFF

(May-June)

(JT-SNOWMELT RUNOFF

(July-September)

LOW FLOW

(October-April)

Figure 18. Median dissolved- and total-recoverable copper concentrations by streamflow regime in the lower Arkansas River, April 1990-March 1993. 

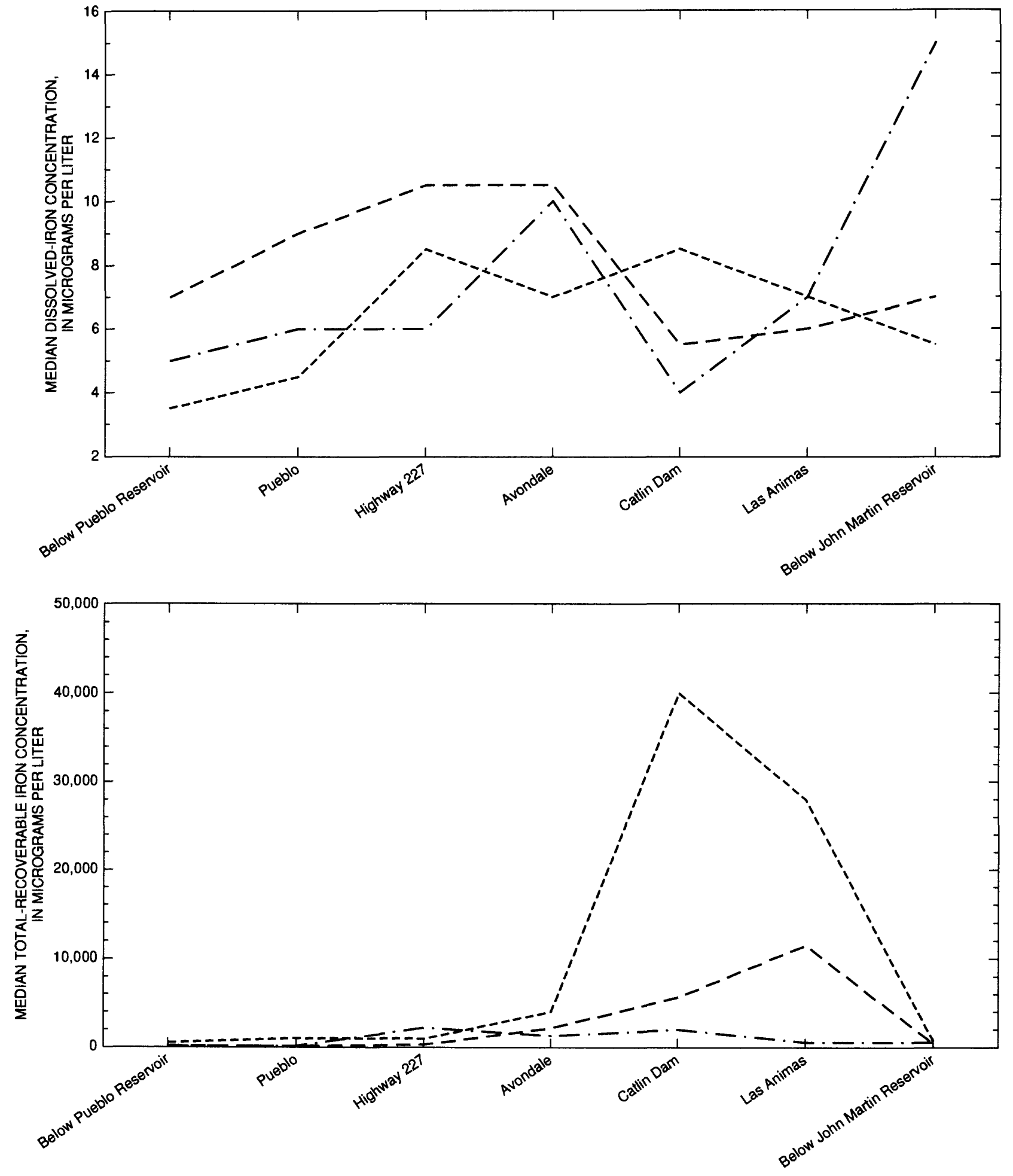

EXPLANATION

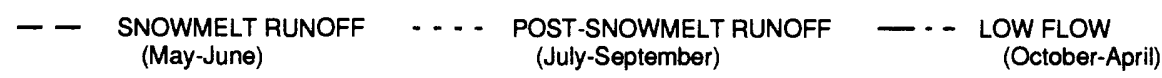

Figure 19. Median dissolved- and total-recoverable iron concentrations by streamflow regime in the lower Arkansas River, April 1990-March 1993. 
Table 22. Number of samples that exceeded chronic iron water-quality standards in the lower Arkansas River, April 1990-March 1993

\begin{tabular}{|c|c|c|c|}
\hline \multirow[b]{2}{*}{$\begin{array}{l}\text { Site name } \\
\text { (see table 1) }\end{array}$} & \multirow[b]{2}{*}{$\begin{array}{l}\text { Number of } \\
\text { samples } \\
\text { analyzed }\end{array}$} & \multicolumn{2}{|c|}{ Number of samples that exceeded standard } \\
\hline & & $\begin{array}{c}\text { Chronic } \\
\text { standard for } \\
\text { dissolved iron } 2\end{array}$ & $\begin{array}{c}\text { Chronic } \\
\text { standard for } \\
\text { total-recoverable } \\
\text { iron }{ }^{3}\end{array}$ \\
\hline Below Pueblo Reservoir & 25 & 0 & $1^{4}$ \\
\hline Pueblo & 23 & 0 & $2^{4}$ \\
\hline Highway 227 & 23 & 1 & 13 \\
\hline Avondale & 22 & 0 & 12 \\
\hline Catlin Dam & 24 & 0 & 19 \\
\hline Las Animas & 23 & 0 & 13 \\
\hline Below John Martin Reservoir & 23 & 0 & 1 \\
\hline
\end{tabular}

of the samples collected at main-stem sites in the lower Arkansas River exceeded the chronic waterquality standard for total-recoverable iron (table 22). These exceedances had no discernible temporal pattern.

\section{Lead}

Dissolved-lead concentrations were less than the reporting limits $(0.5 \mu \mathrm{g} / \mathrm{L}$ from Below Pueblo Reservoir to Avondale; $1 \mu \mathrm{g} / \mathrm{L}$ downstream from Avondale) in nearly all of the samples collected from the lower Arkansas River. Total-recoverable lead concentrations tended to increase downstream from Below Pueblo Reservoir to Avondale (fig. 20). Concentrations typically were largest at most sites during post-snowmelt runoff except at Avondale, where the maximum median total-recoverable lead concentration $(13 \mu \mathrm{g} / \mathrm{L})$ occurred during snowmelt runoff (fig. 20). Inflow from Fountain Creek, which had a median total-recoverable lead concentration of $8 \mu \mathrm{g} / \mathrm{L}$, probably is responsible for the increased concentrations between the Pueblo and Highway 227 sites (fig. 20). Although tributary inflow and resuspension of lead with fluvial sediment are possible causes of the increased concentrations at Avondale, there are no available lead-concentration data for any tributaries between Highway 227 and Avondale to substantiate tributary effects. Dissolved and total-recoverable lead concentrations were analyzed in six samples each at Catlin Dam, Las Animas, and Below John Martin Reservoir. All 18 samples had dissolved-lead concentrations that were less than or equal to the reporting limit $(1 \mu \mathrm{g} / \mathrm{L})$. Based on the analysis of the six samples collected at Catlin Dam and at Las Animas, total-recoverable lead concentrations continued to increase downstream from Avondale. The median total-recoverable lead concentrations at Catlin Dam and at Las Animas were $28.5 \mu \mathrm{g} / \mathrm{L}$ and $26.5 \mu \mathrm{g} / \mathrm{L}$ (Dash and Ortiz, 1996), respectively. Concentrations of total-recoverable lead decreased substantially just downstream from John Martin Reservoir (median value $3.5 \mu \mathrm{g} / \mathrm{L}$ ) probably because of deposition in the reservoir. Lead concentrations did not exceed streamwater-quality standards at any main-stem site in the lower basin.

\section{Manganese}

Median dissolved-manganese concentrations at Portland ranged from 12 to $33 \mu \mathrm{g} / \mathrm{L}$ (fig. 13); just downstream from Pueblo Reservoir, median dissolved-manganese concentrations ranged from 4 to about $27 \mu \mathrm{g} / \mathrm{L}$ (fig. 21). This comparison indicates transport of dissolved manganese through Pueblo Reservoir to the lower basin with some losses to the reservoir that are probably from deposition. In the lower basin, the median dissolved-manganese concentration was relatively constant at the main-stem sites from Pueblo Reservoir to Las Animas (fig. 21). During low flow, median dissolved-manganese concentrations increased from 34 to $1,020 \mu \mathrm{g} / \mathrm{L}$ (thirtyfold increase) between Las Animas and the site immediately below John Martin Reservoir (fig. 21). Dissolved manganese 


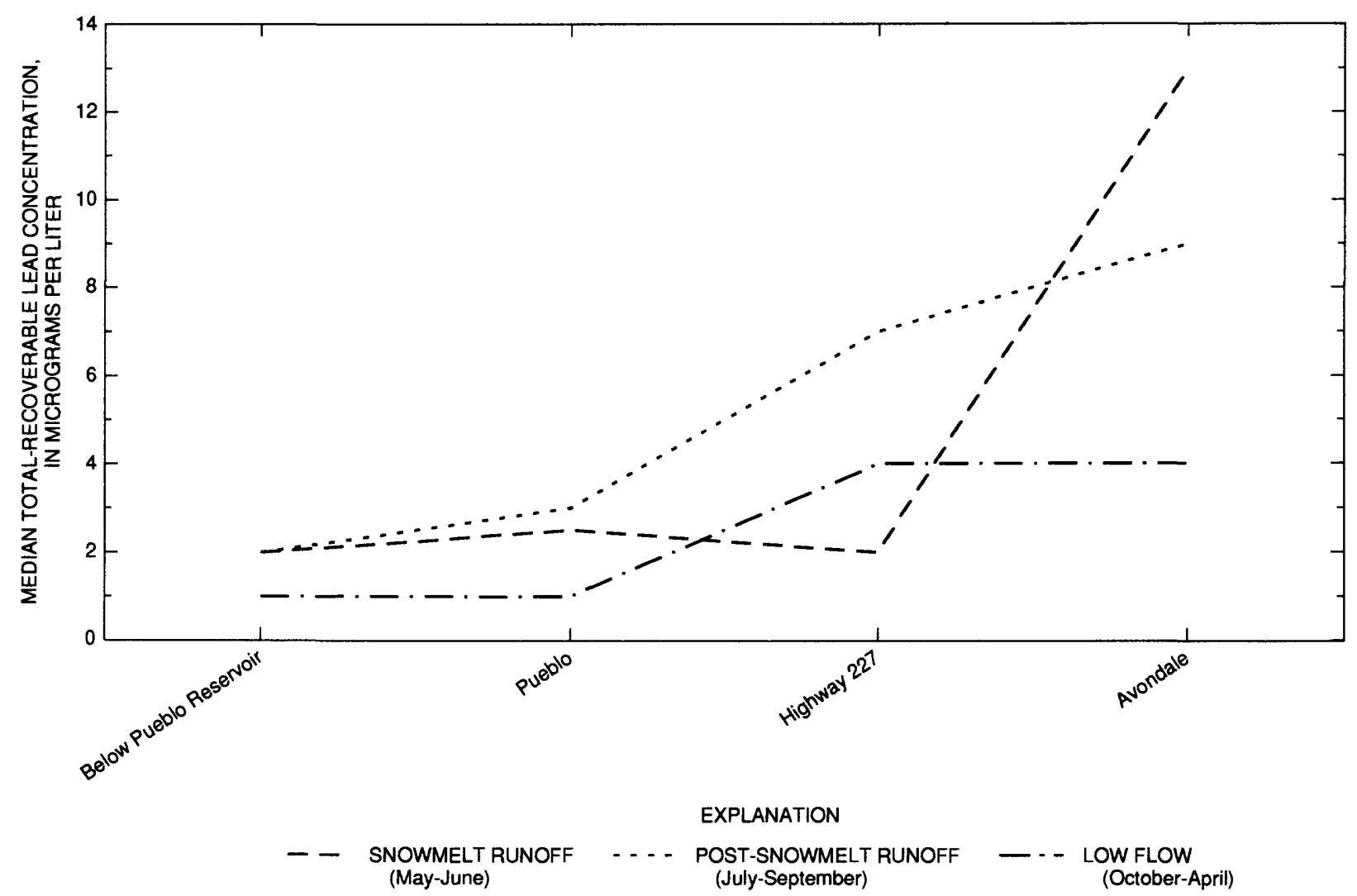

Figure 20. Median total-recoverable lead concentrations by streamflow regime in the lower Arkansas River, April 1990-March 1993.

could have been released from the bottom sediments of John Martin Reservoir during anoxic reservoir conditions. These results are similar to those described for iron and seem to be limited to low-flow regimes. Total-recoverable manganese concentrations generally increased downstream from Pueblo Reservoir. Concentrations increased about 150 to 300 percent between Avondale and Catlin Dam during snowmelt and post-snowmelt runoff regimes (fig. 21) probably because of resuspension and tributary inflow. Two storm-runoff water samples collected from the Apishapa River had total-recoverable manganese concentrations of $5,800 \mu \mathrm{g} / \mathrm{L}$ and $6,400 \mu \mathrm{g} / \mathrm{L}$ (Dash and Ortiz, 1996); these concentrations are about two times higher than the highest instantaneous totalrecoverable manganese concentration measured at any main-stem site in the lower basin. A sample collected from the Purgatoire River during a storm-runoff event had a total-recoverable manganese concentration of $5,300 \mu \mathrm{g} / \mathrm{L}$ (Dash and Ortiz, 1996). About 99 percent of the manganese was in the particulate phase. These three storm-runoff samples indicate that tributary contributions of manganese to the lower Arkansas
River are substantial, especially during rainfall runoff. The substantial increase in total-recoverable manganese concentrations between Las Animas and Below John Martin Reservoir during the low-flow regime, could be caused by the release of dissolved manganese from the reservoir's bottom sediments. There were no exceedances of the chronic stream-water-quality standard for dissolved manganese at any site located upstream from Las Animas (table 23). The chronic stream-water-quality standard for dissolved manganese was exceeded in about 21 percent and about 67 percent of the samples analyzed from the sites Las Animas and Below John Martin Reservoir, respectively (table 23). Sixty-two percent of these exceedances occurred during the low-flow regime. Two samples collected at Catlin Dam and six samples collected at the Below John Martin Reservoir site exceeded the chronic stream-water-quality standard for total-recoverable manganese (table 23). The six exceedances from Below John Martin Reservoir occurred during the low-flow regime and could be attributable to the release of manganese from the reservoir bottom sediments. 

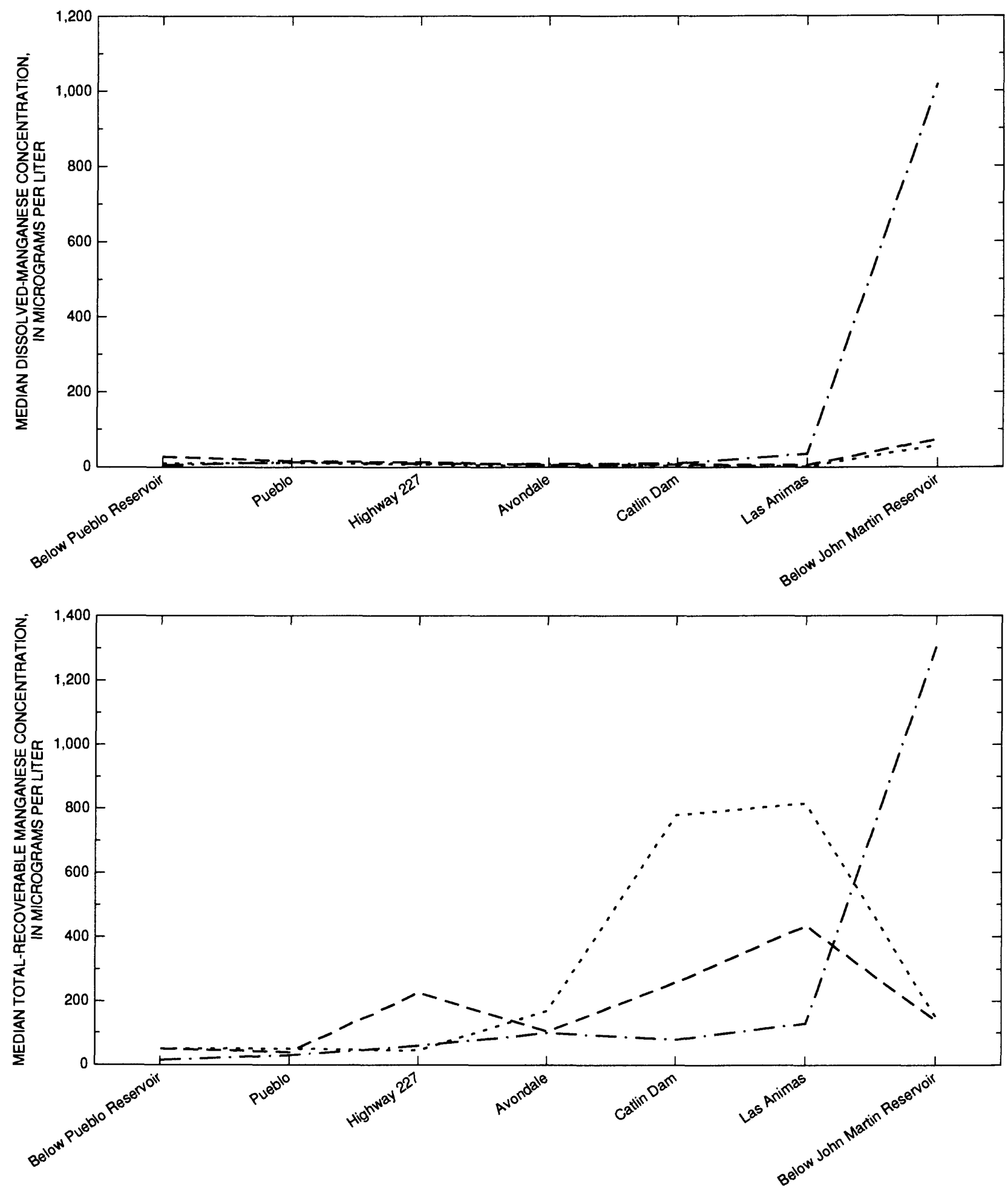

EXPLANATION

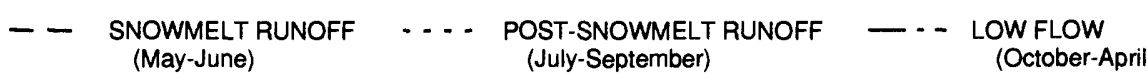

Figure 21. Median dissolved-and total-recoverable manganese concentrations by streamflow regime in the lower Arkansas River, April 1990-March 1993. 
Table 23. Number of samples that exceeded chronic manganese water-quality standards in the lower Arkansas River, April 1990-March 1993

\begin{tabular}{|c|c|c|c|}
\hline \multirow[b]{2}{*}{$\begin{array}{c}\text { Site name } \\
\text { (see table 1) }\end{array}$} & \multirow[b]{2}{*}{$\begin{array}{c}\text { Number of samples } \\
\text { analyzed }\end{array}$} & \multicolumn{2}{|c|}{ Number of samples that exceeded standard } \\
\hline & & $\begin{array}{c}\text { Chronic } \\
\text { standard for } \\
\text { dissolved } \\
\text { manganese }^{2}\end{array}$ & $\begin{array}{c}\text { Chronic } \\
\text { standard for } \\
\text { total-recoverable } \\
\text { manganese }\end{array}$ \\
\hline Below Pueblo Reservoir & 26 & 0 & 0 \\
\hline Pueblo & 26 & 0 & 0 \\
\hline Highway 227 & 24 & 0 & 0 \\
\hline Avondale & 24 & 0 & 0 \\
\hline Catlin Dam & 25 & 0 & 2 \\
\hline Las Animas & 24 & 5 & 0 \\
\hline Below John Martin Reservoir & 24 & 16 & 6 \\
\hline
\end{tabular}

\section{Nickel}

Median dissolved-nickel concentrations at the four main-stem sites in the Pueblo area (fig. 22) were less than $3 \mu \mathrm{g} / \mathrm{L}$, which is within the typical range of dissolved-nickel concentrations in unpolluted surface water (Moore and Ramamoorthy, 1984). Median totalrecoverable nickel concentrations varied minimally and ranged from 2 to $7 \mu \mathrm{g} / \mathrm{L}$ at the four main-stem sites in the Pueblo area (fig. 22). Six water samples were collected at the Catlin Dam, Las Animas, and Below John Martin Reservoir sites and were analyzed for nickel. Concentrations of dissolved nickel ranged from 1 to $7 \mu \mathrm{g} / \mathrm{L}$ at these sites (Dash and Ortiz, 1996), thus indicating no apparent downstream change in concentration. Total-recoverable nickel concentrations were elevated at Catlin Dam and Las Animas, where median concentrations were $23 \mu \mathrm{g} / \mathrm{L}$ and $25 \mu \mathrm{g} / \mathrm{L}$, respectively (Dash and Ortiz, 1996). Resuspension and tributary inflow are possible causes of these increases. The median total-recoverable nickel concentration between Las Animas and Below John Martin Reservoir decreased substantially to $4 \mu \mathrm{g} / \mathrm{L}$, presumably due to deposition in the reservoir. Nickel concentrations in the lower basin did not exceed stream-water-quality standards at any site.

\section{Selenium}

Selenium was analyzed in 16 to 24 samples collected at most main-stem sites in the lower Arkansas River Basin. Only three samples were collected and analyzed for selenium at the Below
Pueblo Reservoir and Highway 227 sites; therefore, these two sites are not included in the seleniumconcentration plots (fig. 23). The downstream temporal patterns in dissolved and total-recoverable selenium concentrations were similar (fig. 23) because more than 90 percent of the total-recoverable selenium was in the dissolved phase. Median concentrations of dissolved selenium typically were largest during the low-flow regime. The maximum median dissolvedselenium concentration $(13.5 \mu \mathrm{g} / \mathrm{L})$ occurred at Las Animas during low flow (fig. 23). In general, dissolved- and total-recoverable selenium concentrations increased downstream to Las Animas; concentrations decreased substantially between Las Animas and Below John Martin Reservoir (fig. 23).

The temporal and spatial patterns in selenium concentrations are a function of local geology, extensive agricultural irrigation, and chemical processes. Cretaceous marine shales and limestones are exposed extensively within the study area (Mueller and others, 1991); concentrations of selenium can be elevated in these shales and limestones compared to concentrations in other rock types (Turekian and Wedepohl, 1961; Hatten, 1969; Schultz and others, 1980). There are about 300,000 acres of irrigated agriculture in the lower Arkansas River Basin, where irrigation water is derived from the Arkansas River and from pumped ground water. Irrigation drain water in the lower Arkansas River Basin flows to the Arkansas River via tributary streams, drainage ditches, and the alluvial aquifer. Cain (1985) reported that downstream from La Junta, much of the streamflow in the Arkansas 

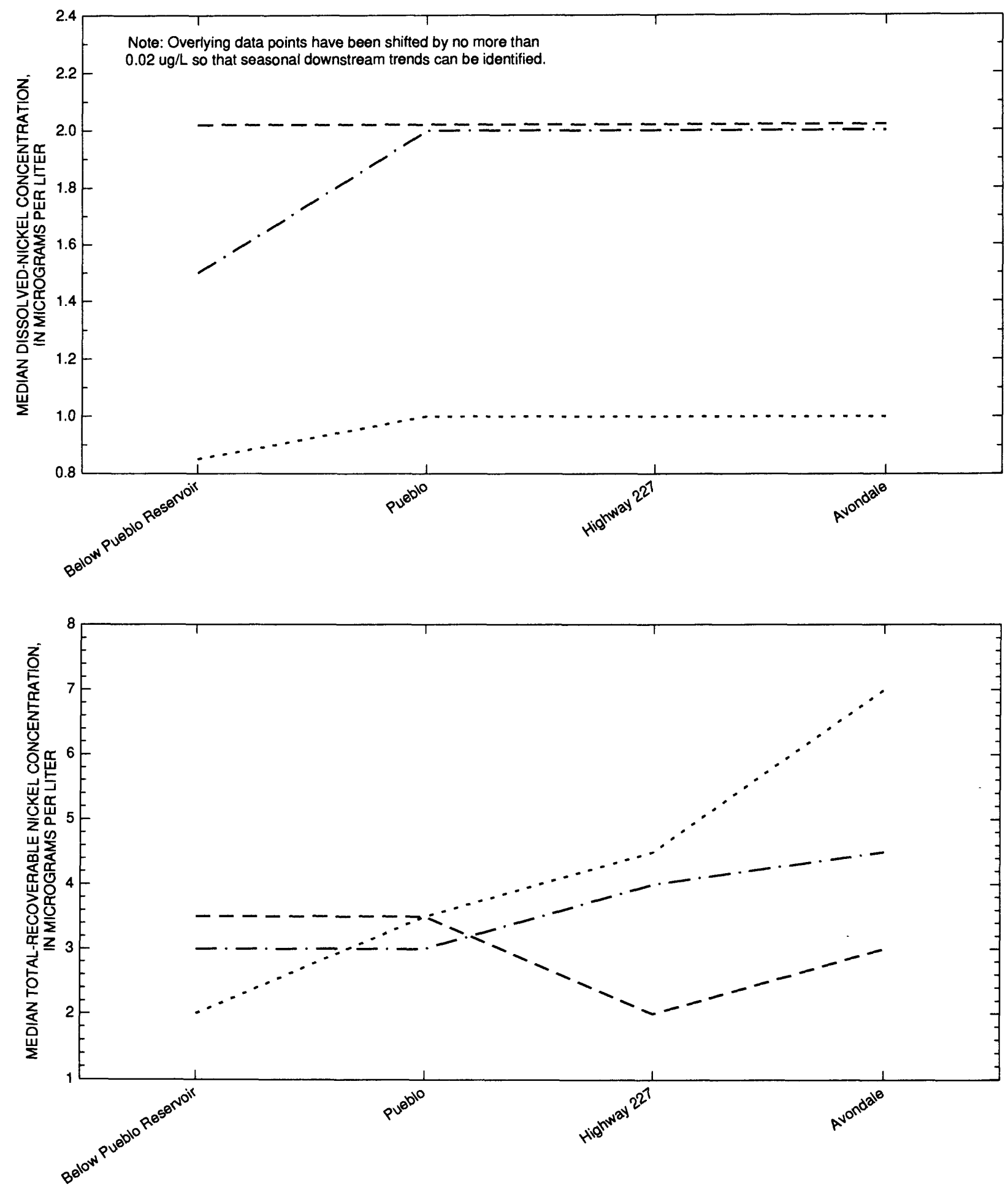

EXPLANATION

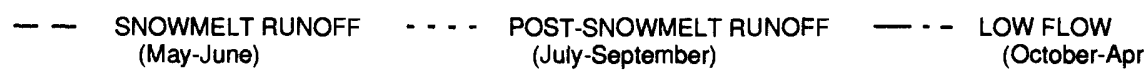

Figure 22. Median dissolved-and total-recoverable nickel concentrations by streamflow regime in the lower Arkansas River, April 1990-March 1993. 

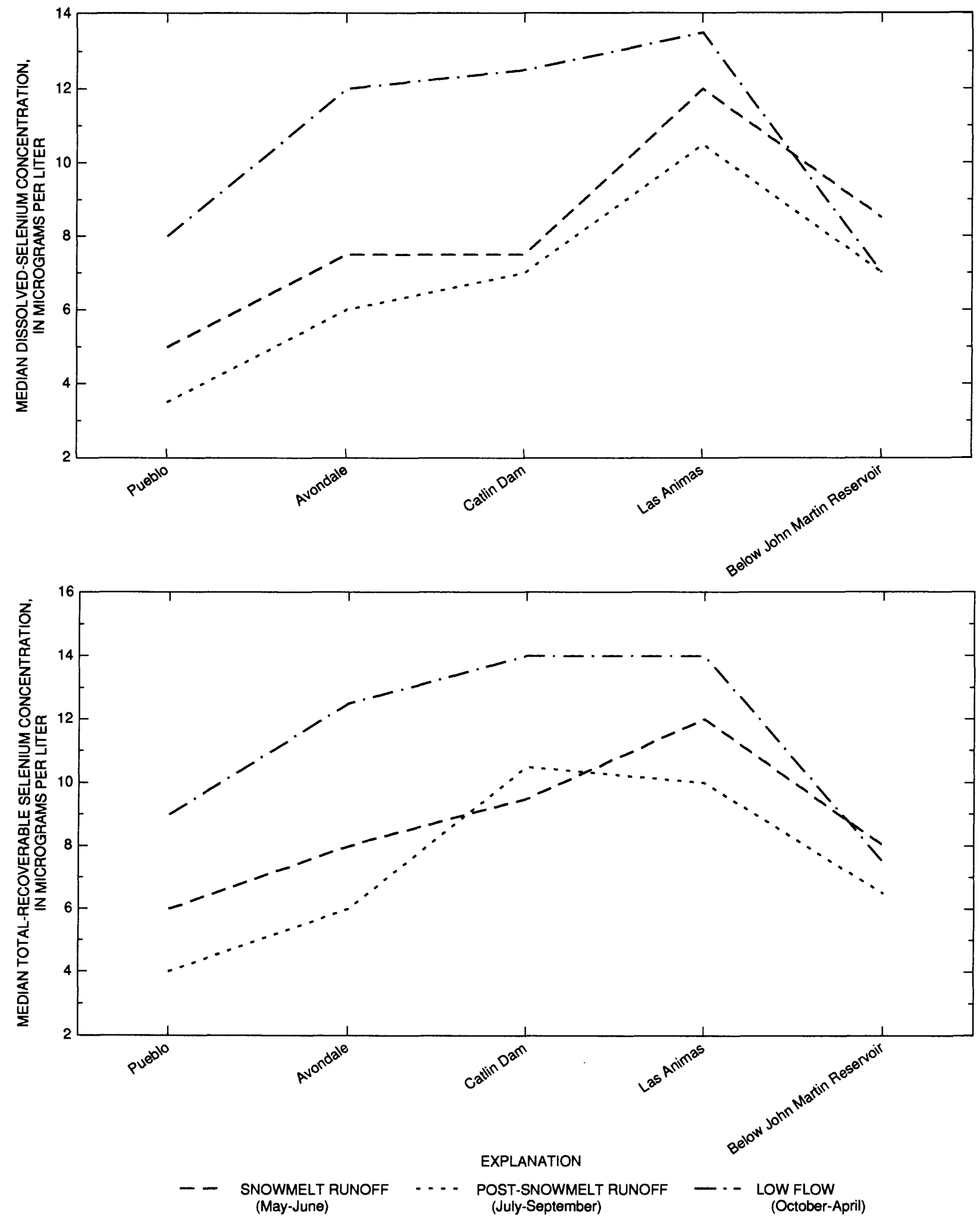

Figure 23. Median dissolved- and total-recoverable selenium concentrations by streamflow regime in the lower Arkansas River, April 1990-March 1993. 
River is derived from these irrigation return flows. The extensive application of irrigation water can leach selenium from the seleniferous soils and rocks in the study area. Thus, local geology and irrigation return flows are the two most likely causes of the increasing selenium concentrations between Pueblo and Las Animas (fig. 23).

Selenium concentrations were largest during the low-flow regime when streamflow and irrigation return flows were less diluted by the river. The apparent decrease in selenium concentrations between the Las Animas and Below John Martin Reservoir sites (fig. 23) seems to have been caused by a process that removed dissolved selenium from the water column and stored it in the biota or bottom sediments. Oremland and others (1989) have demonstrated the possibility of such a process involving the bacterial reduction of selenate, the most mobile inorganic selenium species, under anoxic conditions. Selenite, which is relatively insoluble, is expected to be the most common selenium species under anoxic conditions. Selenite has been shown to readily sorb to ferric oxides, thus controlling the selenium concentration in solution (Brown, 1991).

Total-recoverable selenium concentrations frequently exceeded the chronic stream-water-quality standard of $10 \mu \mathrm{g} / \mathrm{L}$ at several sites in the lower basin (table 24). The frequency of exceedance was largest at Catlin Dam and at Las Animas, where about

Table 24. Number of samples that exceeded chronic selenium water-quality standards in the lower Arkansas River, April 1990-March 1993

\begin{tabular}{lcc}
\hline \multicolumn{1}{c}{$\begin{array}{c}\text { Site name } \\
\text { (see table 1) }\end{array}$} & $\begin{array}{c}\text { Number of } \\
\text { samples } \\
\text { analyzed }\end{array}$ & $\begin{array}{c}\text { Number of } \\
\text { samples that } \\
\text { exceeded chronic } \\
\text { standard for total- } \\
\text { recoverable } \\
\text { selenium }\end{array}$ \\
\hline Below Pueblo Reservoir & 3 & 0 \\
Pueblo & 16 & 1 \\
Highway 227 & 3 & 2 \\
Avondale & 16 & 7 \\
Catlin Dam & 24 & 14 \\
Las Animas & 24 & 17 \\
Below John Martin Reservoir & 23 & 1 \\
\hline
\end{tabular}

${ }^{1}$ Chronic selenium standard (10 micrograms per liter) is based on total-recoverable selenium concentration (Colorado Department of Health, 1994).
58 percent and about 71 percent of the samples exceeded the standard, respectively (table 24 ). Selenium concentrations exceeded the stream-waterquality standard during all three flow regimes, although the standard was exceeded more frequently during the low-flow regime.

\section{Silver}

Dissolved and total-recoverable silver concentrations were less than the reporting limit $(1 \mu \mathrm{g} / \mathrm{L})$ in nearly all of the samples that were collected in the lower basin. The analytical reporting limit was too large to indicate if silver occurred at concentrations that might be toxic to aquatic life.

\section{Zinc}

A comparison of the median dissolved- and total-recoverable zinc concentrations at Portland (fig. 15) and Below Pueblo Reservoir (fig. 24) indicates that very little zinc was transported through Pueblo Reservoir from the upper basin. In the lower basin, the median dissolved-zinc concentrations ranged from about 2 to $7 \mu \mathrm{g} / \mathrm{L}$ and varied extensively (fig. 24). The median total-recoverable zinc concentration ranged from 7 to $200 \mu \mathrm{g} / \mathrm{L}$; the maximum totalrecoverable zinc concentration $(200 \mu \mathrm{g} / \mathrm{L})$ occurred at Catlin Dam during the post-snowmelt runoff regime (fig. 24). Total-recoverable zinc concentrations varied little at most sites during the low-flow regime but tended to increase downstream from Avondale during the snowmelt-runoff and post-snowmelt runoff regimes (fig. 24). This increase probably is attributable to resuspension and tributary inflow. In the two stormrunoff samples that were collected from the Apishapa River and in the one sample collected from the Purgatoire River, the total-recoverable zinc concentrations were $1,300,850$, and $1,000 \mu \mathrm{g} / \mathrm{L}$, respectively (Dash and Ortiz, 1996). The total-recoverable zinc concentrations tended to decrease between Las Animas and the site just downstream from John Martin Reservoir (fig. 24), probably because of deposition within the reservoir. Zinc concentrations did not exceed the stream-water-quality standards at any main-stem site in the lower Arkansas River Basin. 

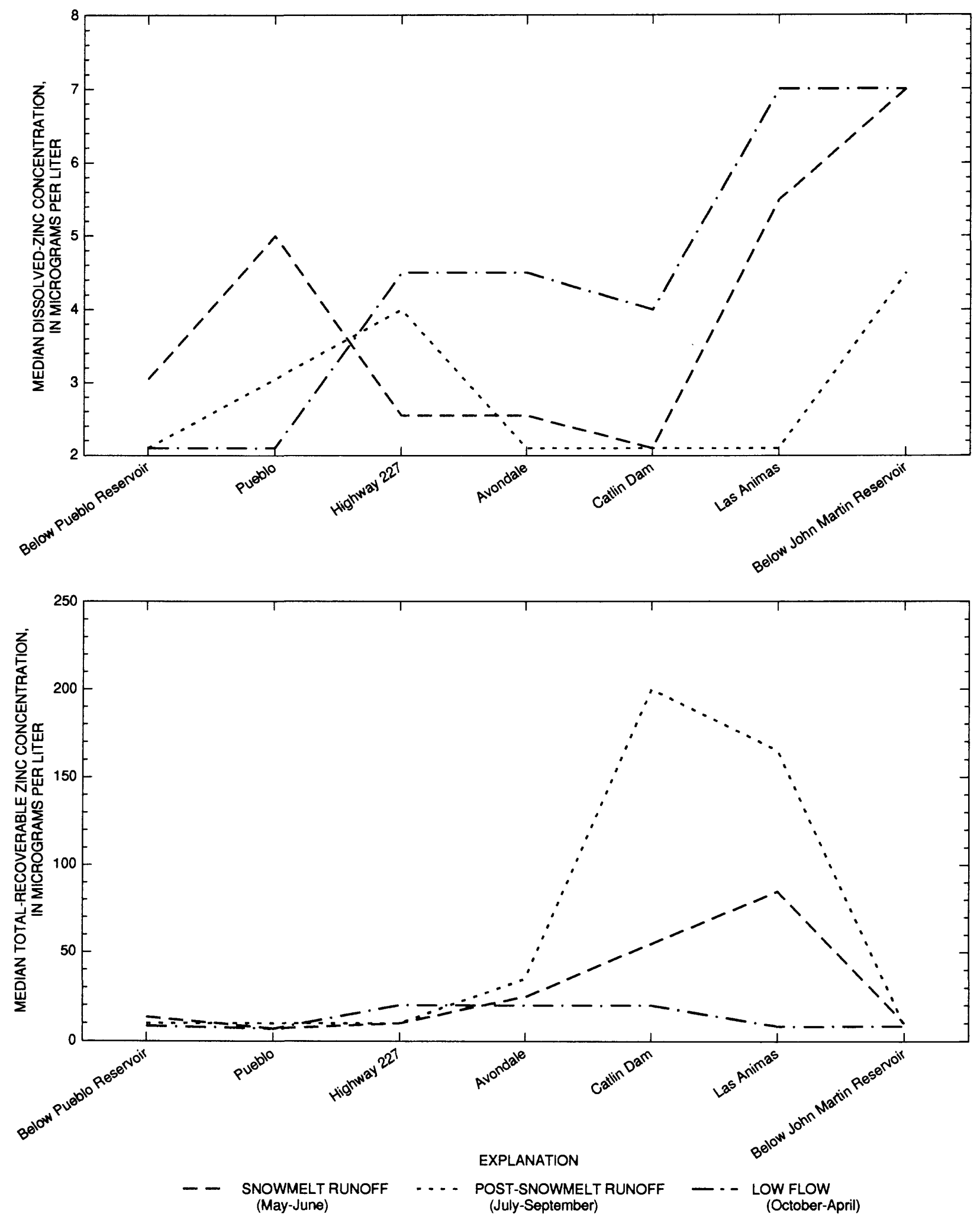

Figure 24. Median dissolved- and total-recoverable zinc concentrations by streamflow regime in the lower Arkansas River, April 1990-March 1993. 


\section{Nutrients}

Nutrients collected and analyzed as part of this study were total ammonia (hereinafter referred to as ammonia), total nitrite plus nitrate (hereinafter referred to as nitrate), and total phosphorus (hereinafter referred to as phosphorus). Water samples for analysis of ammonia and nitrate concentrations were collected 24 to 28 times at all 20 main-stem sites. Samples for phosphorus were collected 24 to 28 times at 13 main-stem sites. Tributaries generally were sampled less frequently. Different reporting limits were used for sites in the upper and lower Arkansas River Basin because nutrient samples collected in the upper Arkansas River Basin had much lower concentrations than those in the lower basin.

Potential major nutrient sources include several municipal wastewater-treatment facilities and nonpoint-source loading from agricultural return flow, domestic livestock, feedlots, and septic systems. In the upper basin, municipal wastewater sources include facilities for Leadville, Buena Vista, Salida, and the Fremont Sanitation District (Gary Soldano, Colorado Department of Public Health and Environment, written commun., 1996). The town of Leadville uses secondary wastewater treatment and discharges directly into California Gulch about one-half mile upstream from the confluence with the Arkansas River and the water-quality site on California Gulch. Buena Vista uses a lagoon system that uses evaporation and discharges to ground water. Wastewater treatment at Salida uses secondary treatment and discharges to the Arkansas River. Fremont Sanitation District uses secondary treatment for Cañon City, Florence, and several penal institutions and discharges to the Arkansas River between Florence and Portland (pl. 1). In the lower basin, municipal wastewater sources include wastewater-treatment facilities for Pueblo, Colorado Springs, Security Sanitation District, Widefield, Fountain Sanitation District, Fowler, Manzanola, Rocky Ford, La Junta, Las Animas, and Lamar (Gary Soldano, Colorado Department of Public Health and Environment, written commun., 1996). The cities of Pueblo, Colorado Springs, Security, Widefield, and La Junta use secondary wastewater treatment. Colorado Springs has since upgraded to advanced wastewater treatment (William Vanderveer, Colorado Springs Utilities, written commun., 1996). Pueblo and La Junta discharge to the Arkansas River; Colorado Springs, Security, and Widefield discharge to Fountain
Creek. Wastewater pond systems are used at the remaining locations.

\section{Ammonia}

Ammonia concentrations in the upper Arkansas River Basin generally increased downstream (fig. 25). Median ammonia concentrations for main-stem sites ranged from $0.010 \mathrm{mg} / \mathrm{L}$ at Leadville and Buena Vista to $0.026 \mathrm{mg} / \mathrm{L}$ at Wellsville. California Gulch, which receives wastewater discharge from Leadville, had the highest median ammonia concentration $(2.15 \mathrm{mg} / \mathrm{L})$ in the upper basin. Several other tributaries in the Leadville area, including Iowa Gulch and Empire Gulch (pl. 1), contributed to the elevated ammonia concentrations in the Arkansas River downstream from California Gulch. Median concentrations of ammonia increased steadily from Buena Vista to Wellsville with a significant increase $(\alpha=0.05)$ in concentration occurring between Salida and Wellsville. Increased ammonia concentrations probably were due to discharges from wastewater facilities in the reach, although other potential sources in this reach include nonpoint-source loading from livestock and septic systems. Ammonia concentrations generally decreased along the 52-mi stream reach from Wellsville to Parkdale, probably due to dilution and assimilation of nitrogen by aquatic plants. Tributary inputs, with the exception of those in the Leadville area, did not contribute substantial amounts of ammonia to the upper Arkansas River; typically, tributaries contributed less than 15 percent of the load within a stream reach.

In the lower Arkansas River Basin, median ammonia concentrations at main-stem sites ranged from $0.020 \mathrm{mg} / \mathrm{L}$ at Nepesta and Las Animas to $0.145 \mathrm{mg} / \mathrm{L}$ at Below John Martin Reservoir (fig. 25). Substantially larger ammonia concentrations were analyzed just downstream from Pueblo Reservoir than at Portland. Lewis and Edelmann (1994) indicated that inorganic nitrogen concentrations were larger in the deeper portions of Pueblo Reservoir because of reduced biologic uptake and releases of nitrogen from the bottom sediments. Nutrients released from the bottom sediments in deep-water withdrawal reservoirs, like Pueblo Reservoir, may be discharged downstream, thus increasing concentrations in the river. Ammonia concentrations decreased through the city of Pueblo, probably because of nitrification of ammonia and assimilation of ammonia by aquatic plants. 


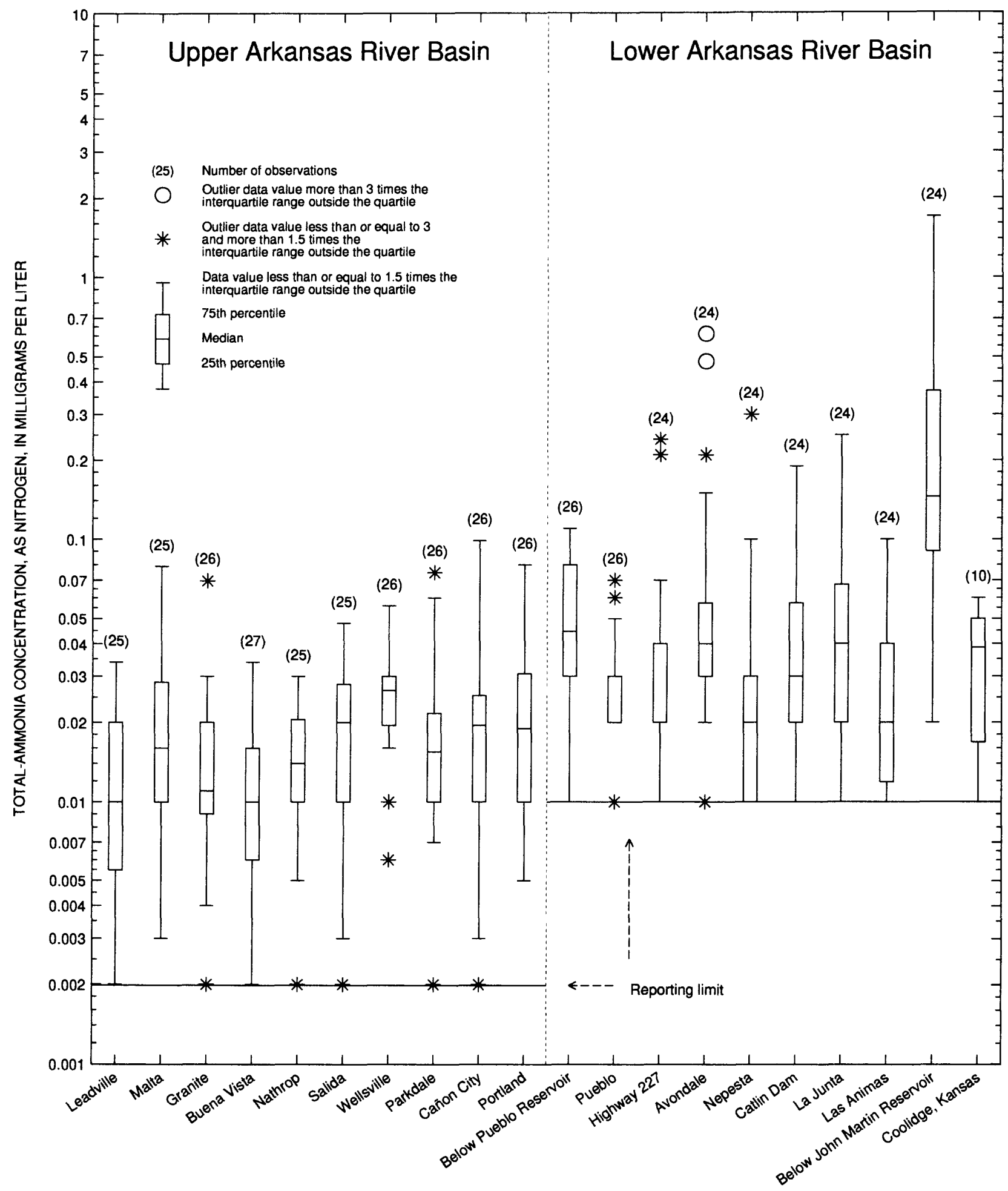

Figure 25. Variations in total-ammonia concentrations in the Arkansas River, April 1990-March 1993. 
Ammonia concentrations remained relatively stable downstream to Las Animas. Substantial increases in ammonia concentrations ( 625 percent) occurred between Las Animas and just downstream from John Martin Reservoir (fig. 25). The occurrence of high ammonia concentrations immediately downstream from John Martin Reservoir, particularly during winter, is suggestive of anoxic conditions in John Martin Reservoir. As a result, the reduction of nitrogen compounds, such as nitrate, may occur in the reservoir. Concentrations of ammonia decreased downstream from the Below John Martin Reservoir station because of nitrification and assimilation of ammonia.

At most stations, the median ammonia concentrations were relatively constant throughout most of the year, with the exception of the station Below Pueblo Reservoir (fig. 26). Concentrations were elevated at the Below Pueblo Reservoir station during the snowmelt-runoff regime (May-June).

Ammonia concentrations in the Arkansas River were low in comparison to stream-water-quality standards and drinking-water standards. There were no exceedances of the stream-water-quality standards for un-ionized ammonia. The chronic and acute streamwater-quality standards for un-ionized ammonia are $0.02 \mathrm{mg} / \mathrm{L}$ and $0.43 \mathrm{mg} / \mathrm{L}$, respectively (Colorado Department of Health, 1994). It is important to recognize that the standards for ammonia are based on unionized ammonia and that data from this study are reported as total ammonia, which includes un-ionized and ionized ammonia. Analysis of total ammonia concentrations indicated that un-ionized ammonia concentrations were less than 10 percent of the total ammonia concentration. On the basis of this analysis, un-ionized ammonia concentrations in the basin did not exceed stream-water-quality standards.

\section{Nitrate}

Median nitrate concentrations in the upper basin ranged from $0.020 \mathrm{mg} / \mathrm{L}$ at Granite to $0.130 \mathrm{mg} / \mathrm{L}$ at Portland (fig. 27). California Gulch had the highest median nitrate concentration in the upper basin $(0.51 \mathrm{mg} / \mathrm{L})$ and, along with Iowa Gulch and Empire Gulch, contributed to the elevated nitrate concentration at Malta. A significant decrease $(\alpha=0.05)$ in nitrate concentration occurred just upstream from Granite as water released from Twin Lakes Reservoir diluted the flow in the Arkansas River. Concentrations of nitrate generally increased between Granite and
Wellsville with significant $(\alpha=0.05)$ increases occurring between Buena Vista and Nathrop and between Salida and Wellsville. Wastewater facilities and nonpoint loading from livestock and septic systems probably contributed to the increases. As was the case with ammonia, nitrate concentrations decreased between Wellsville and Portland probably due to dilution and assimilation of nitrogen by aquatic plants. Between Cañon City and Portland, a threefold increase in median nitrate concentration $(0.046$ to $0.13 \mathrm{mg} / \mathrm{L}$ ) likely occurred because of discharge from the Fremont Sanitation Wastewater Treatment Facility and nonpoint sources such as agricultural return flow and livestock. Tributary inputs downstream from Malta did not contribute substantial amounts of nitrate to the upper Arkansas River.

Median nitrate concentrations at main-stem sites in the lower Arkansas River Basin ranged from 0.20 to $2.4 \mathrm{mg} / \mathrm{L}$ (fig. 27). Nitrate concentrations immediately downstream from Pueblo Reservoir were larger than at Portland probably because of the same processes that resulted in increased ammonia concentrations in the water released from Pueblo Reservoir. Median nitrate concentrations increased twofold between the Pueblo and Highway 227 sites because of inflow from Fountain Creek (fig. 27); the concentrations in Fountain Creek are elevated because of upstream wastewater discharges and irrigation return flows. The highest median nitrate concentration in the basin was at Fountain Creek $(4.7 \mathrm{mg} / \mathrm{L})$. Downstream to Avondale, median nitrate concentrations showed a steady and significant $(\alpha=0.05)$ increase. The increase can probably be attributed to wastewater discharges from Pueblo and agricultural and urban nonpointsource runoff. Nitrate concentrations remained relatively constant downstream from Avondale to Catlin Dam, then increased downstream to La Junta. The increase observed at La Junta is probably attributable to irrigation return flows and wastewater discharge from the city of La Junta. Timpas Creek and Crooked Arroyo (pl. 1), which largely consisted of irrigation return flow, had nitrate concentrations that ranged from about $2 \mathrm{mg} / \mathrm{L}$ to $6 \mathrm{mg} / \mathrm{L}$. Two large feedlots that operate in the area also may have contributed nitrate to the river. The significant $(\alpha=0.05)$ decrease in nitrate concentrations at Below John Martin Reservoir was possibly caused by assimilation within the reservoir and chemical reduction or denitrification during periods of anoxia in the reservoir. Nitrate concentrations increased fivefold between the 

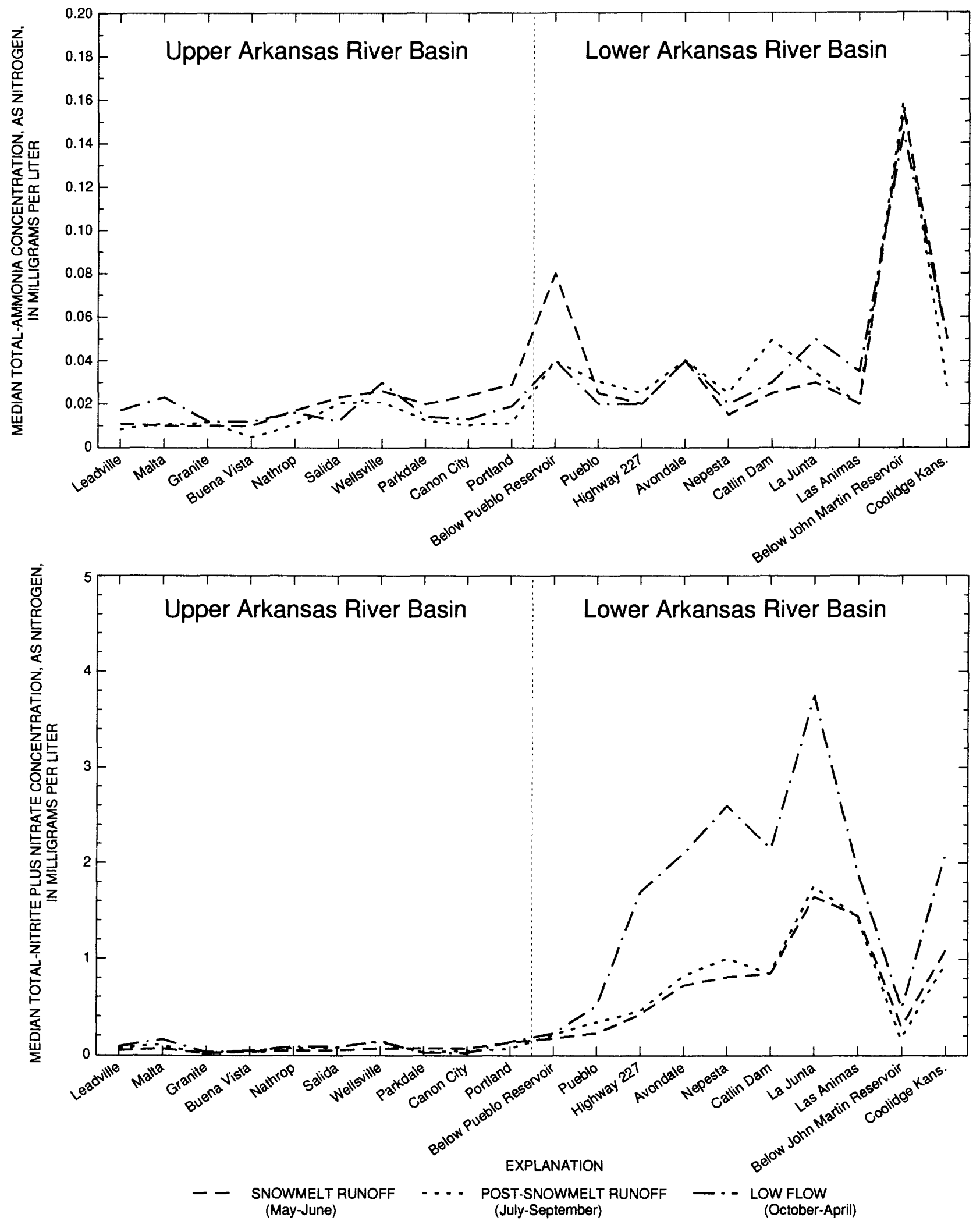

Figure 26. Median total-ammonia and total-nitrite plus nitrate concentrations by streamflow regime in the Arkansas River, April 1990-March 1993. 


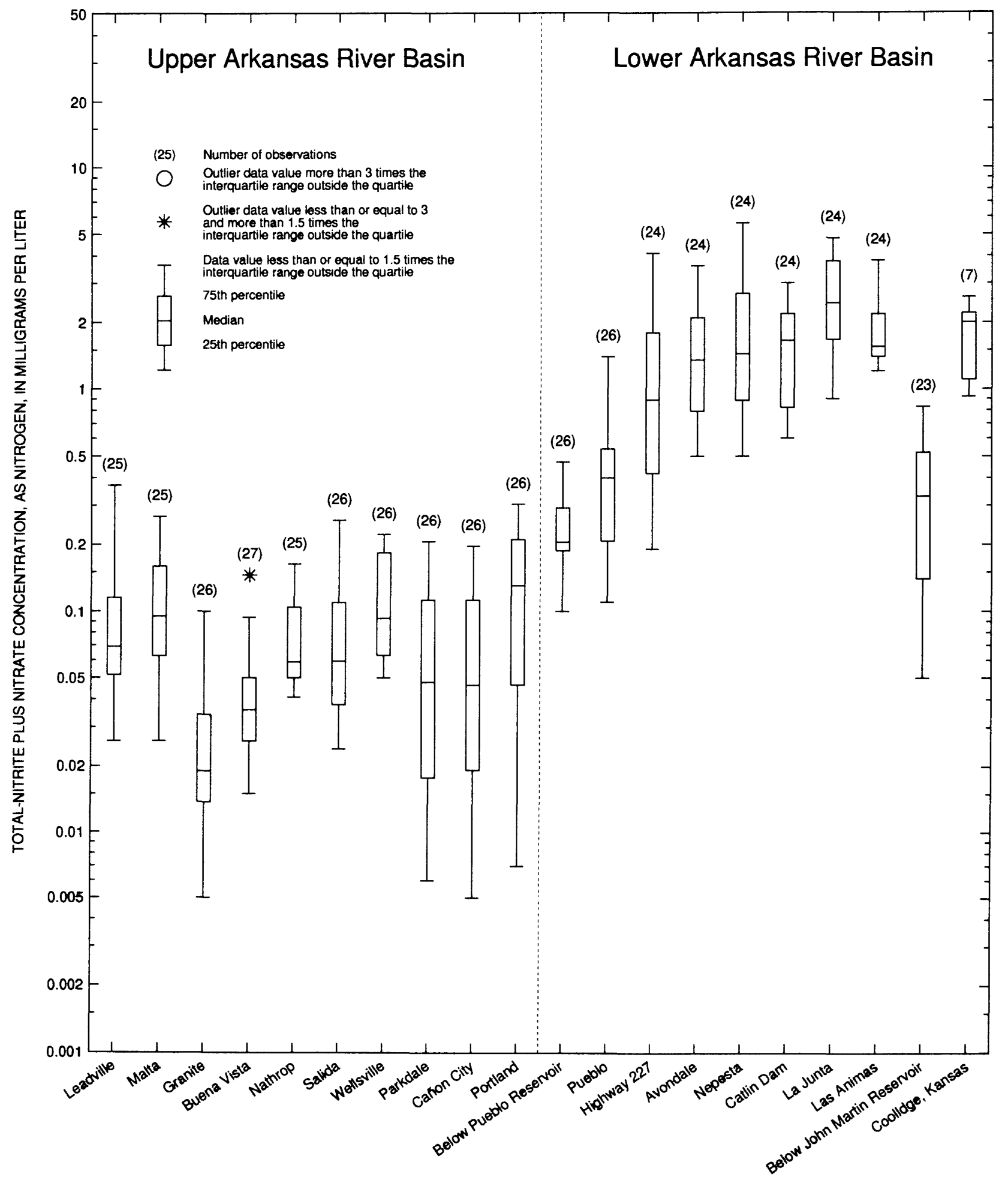

Figure 27. Variations in total-nitrite plus nitrate concentrations in the Arkansas River, April 1990-March 1993. 
Below John Martin Reservoir and Coolidge, Kans., sites probably due to the prevalence of irrigation return flows in the reach.

Temporal variability in nitrate concentrations was apparent, particularly in the lower Arkansas River Basin. Median concentrations were higher during lowflow (October-April) than during either the snowmeltrunoff (May-June) or post-snowmelt runoff (JulySeptember) regime (fig. 26). Low-flow conditions resulted in less dilution in the river, possibly resulting in higher concentrations during this regime. Concentrations during snowmelt-runoff and post-snowmelt runoff regimes were similar throughout the lower basin. A Spearman's rank correlation test was used to determine whether nitrate concentrations changed with streamflow. This nonparametric test uses the ranks of the data to determine the strength of the association of the variables. Spearman correlation coefficients, or $r$ values, range from -1 to +1 , and data are highly correlated as these bounds are approached. When $r=0$, there is no correlation. The Spearman's rank test indicated there was an inverse relation between streamflow and nitrate concentrations in the lower basin. Main-stem sites from Pueblo to La Junta had $r$ values ranging from -0.68 to -0.89 . The negative sign indicates an inverse relation; that is, nitrate concentrations decreased as streamflow increased. All probabilities were significant at the $\alpha=0.05$ level.

Nitrate concentrations in the Arkansas River were low in comparison to stream-water-quality standards and drinking-water standards. The streamwater-quality standard for nitrate is $10 \mathrm{mg} / \mathrm{L}$ and was not exceeded in any sample. Although nitrate concentrations generally increased downstream throughout the basin, concentrations did not exceed stream-waterquality standards at any site.

\section{Phosphorus}

Phosphorus concentrations generally were lower in the upper basin than in the lower basin (fig. 28). Median concentrations in the upper Arkansas River ranged from less than $0.01 \mathrm{mg} / \mathrm{L}$ at Nathrop to $0.05 \mathrm{mg} / \mathrm{L}$ at Portland. Concentrations in the lower basin ranged from $0.02 \mathrm{mg} / \mathrm{L}$ at Pueblo to $0.28 \mathrm{mg} / \mathrm{L}$ at Avondale. Concentrations increased significantly $(\alpha=0.05)$ between the Pueblo and Highway 227 sites, probably due to inflow from Fountain Creek; the median phosphorus concentration at the Fountain Creek site was $0.96 \mathrm{mg} / \mathrm{L}$. Median concentrations more than doubled in the river downstream to Avondale. Median phosphorus concentrations at Highway 227, Avondale, and Catlin Dam exceeded the EPA recommendation of $0.1 \mathrm{mg} / \mathrm{L}$ for total phosphorus in rivers (U.S. Environmental Protection Agency, 1986a). The median concentration at Las Animas $(0.10 \mathrm{mg} / \mathrm{L})$ exceeded the threshold value of 0.05 $\mathrm{mg} / \mathrm{L}$ as recommended by the Environmental Protection Agency for total phosphorus in a river entering a reservoir (U.S. Environmental Protection Agency, 1986a). There was no distinct temporal pattern in the phosphorus concentrations.

\section{Radiochemical Constituents}

Water-quality samples for radiochemical analyses were collected periodically from 1990 through 1992 at eight surface-water sites on the main stem of the Arkansas River. The samples were analyzed for natural uranium, gross alpha (expressed as natural uranium), and gross beta (expressed as cesium-137 and strontium-90/yttrium-90). Forty-nine samples were analyzed for dissolved uranium, 4 to 8 samples at each site, and 46 samples were analyzed for gross alpha and gross beta, 5 to 7 samples at each site.

Relatively high levels of natural uranium occur in the Rocky Mountain region of the United States (U.S. Environmental Protection Agency, 1986b), and parts of southeastern Colorado have been identified as having consistently high concentrations of dissolved uranium in surface and ground water (Shannon, 1979). Several possible contributing factors for the high concentrations of dissolved uranium include composition bedrock, land use, and concentration of dissolved constituents due to evapotranspiration. Large parts of southeastern Colorado are underlain by marine shale (Pierre Shale) and limestone of Late Cretaceous age (Zielinski and others, 1995). Some sedimentary rocks, especially marine shales, have been shown to have greater than normal radioactivity due to uranium, thorium, and potassium (Pettijohn, 1949). Agriculture is the predominant land use along the lower Arkansas River; water initially diverted from the river is used for irrigation, then the return flows are used again for irrigation, and eventually the water returns to the river. This reuse of water increases the amount of time the soil and rock can interact with the water, resulting in further dissolution of minerals and increased ionexchange interaction, which is indicated by the 


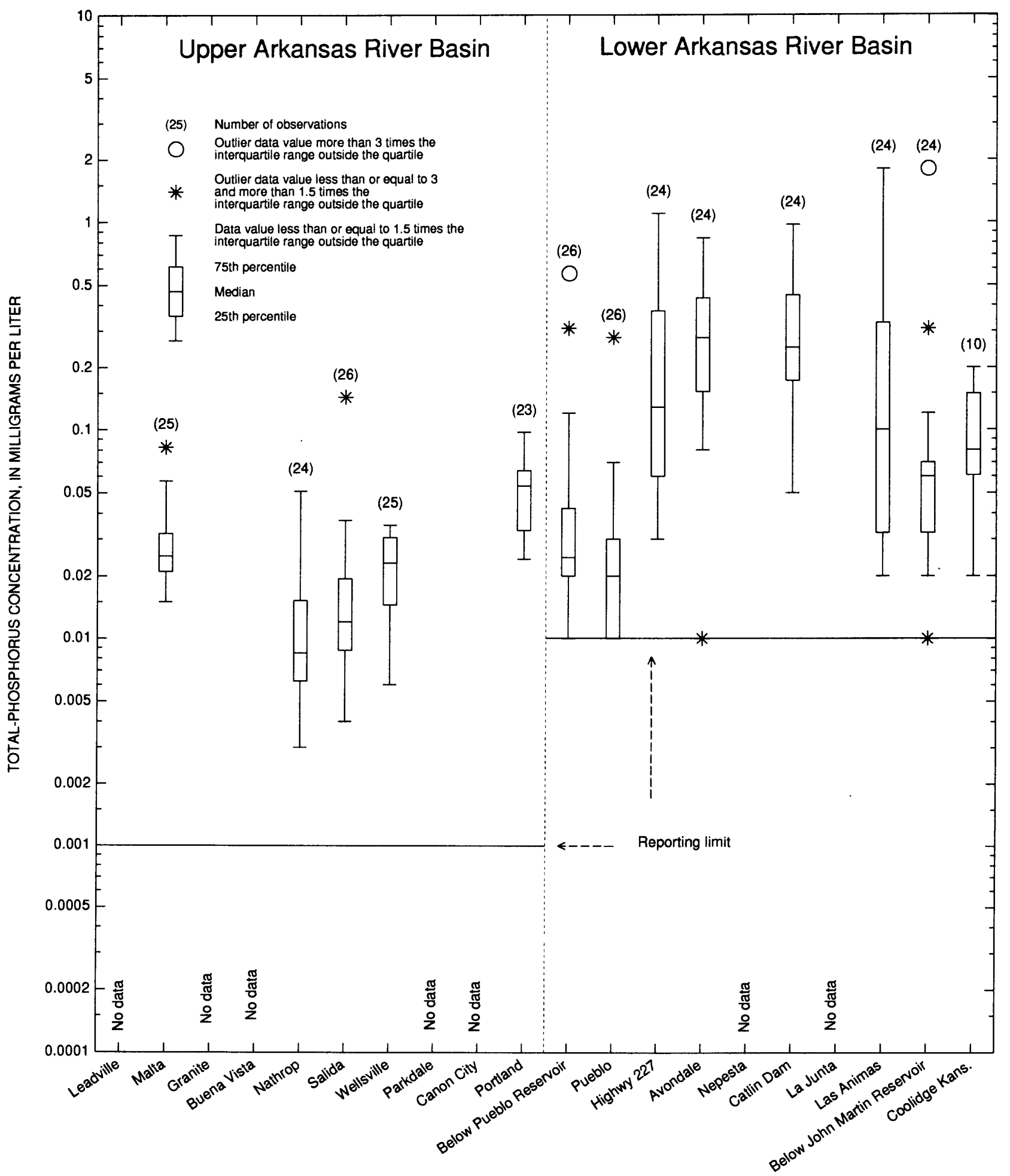

Figure 28. Variations of total-phosphorus concentrations in the Arkansas River, April 1990-March 1993. 
increased concentration of major dissolved constituents, as well as dissolved uranium in the lower Arkansas River Basin. Zielinski and others (1995) identified increased uranium concentrations as the river flowed out onto agriculturally developed lands underlain by marine shale and limestone. A marked increase in uranium also was observed along the reach of the river where irrigation return flow can make up most of the streamflow in the Arkansas River. Uranium samples collected as part of this study showed the same downstream trend (fig. 29).

Adverse effects associated with exposure to uranium are a concern to water users because of its radioactive nature and its ubiquitous occurrence in the environment. The proposed drinking-water standard for natural uranium is $20 \mu \mathrm{g} / \mathrm{L}$ and is based on protection from kidney toxicity (U.S. Environmental Protection Agency, 1991). The Colorado Water Quality Control Commission (Colorado Department of Health, 1994) adopted an instream uranium standard of $40 \mathrm{pCi} / \mathrm{L}(58.8 \mu \mathrm{g} / \mathrm{L})$ or natural background where natural concentrations exceed $40 \mathrm{pCi} / \mathrm{L}$. The standard was based on approximate routine human exposures given the background concentrations present in Colorado and the small statistical risk of human health hazards at this concentration. Instantaneous dissolved natural uranium concentrations exceeded the proposed drinking-water standard at two sites, once at Las Animas $(36 \mu \mathrm{g} / \mathrm{L})$ and twice at Below John Martin Reservoir $(29 \mu \mathrm{g} / \mathrm{L})$. The median value for dissolved

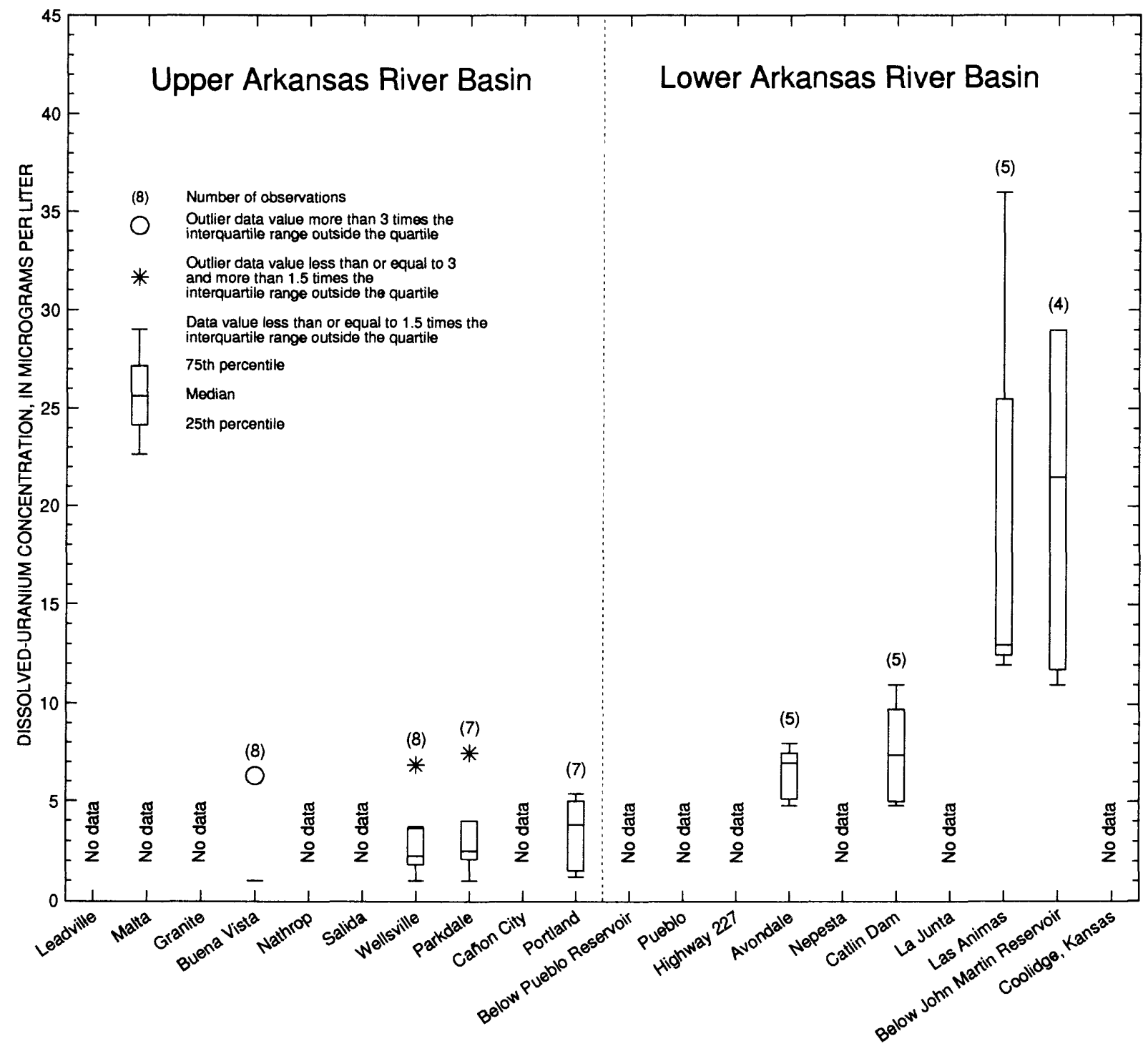

Figure 29. Variations in dissolved-uranium concentrations in the Arkansas River, April 1990-March 1993. 
uranium downstream from John Martin Reservoir also exceeded the proposed drinking-water standard.

A Spearman's rho correlation analysis of uranium with total dissolved solids, specific conductance, major dissolved ions, and selected dissolved trace elements shows strong correlation except for manganese (table 25). The strong positive correlation between uranium and specific conductance $(r=0.91)$ indicates that uranium is soluble and is conserved in solution (Zielinski and others, 1995). Major dissolved constituents show strong positive correlation $(r>0.87)$ probably because processes that result in elevated dissolved-solids concentrations also result in elevated dissolved uranium concentrations. Uranium also shows strong positive correlation with selenium $(r=0.82)$. Selenium can be elevated in the shales and limestones commonly present in the lower Arkansas River Basin (Turekian and Wedepohl, 1961; Hatten, 1969; Schultz and others, 1980) and can concentrate in oxic saline waters of the Western United States (Zielinski and others, 1995).

The gross alpha and gross beta analyses are regarded as a rapid, quantitative measure of gross sample activity (Thatcher and others, 1977). Gross alpha activity serves as a gross indicator for high levels of natural radionuclides and is used in particular to screen for radium (U.S. Environmental Protection Agency, 1986b). The principal sources for naturally occurring radioactivity in water are the weathering of

Table 25. Spearman's coefficients of correlation for dissolved uranium and selected water-quality constituents in the Arkansas River, April 1990-March 1993

[n, number of paired values; $<$, less than]

\begin{tabular}{lccc}
\hline \multicolumn{1}{c}{$\begin{array}{c}\text { Constituent or } \\
\text { characteristic }\end{array}$} & $\mathbf{n}$ & $\begin{array}{c}\text { Correlation } \\
\text { coefficient }\end{array}$ & $\begin{array}{c}\text { Probability } \\
\text { value }\end{array}$ \\
\hline Specific conductance & 47 & 0.91 & $<0.001$ \\
$\begin{array}{l}\text { Total dissolved solids, } \\
\quad \text { residue at }\end{array}$ & 39 & .96 & $<.001$ \\
$\quad 180$ degrees Celsius & & & \\
Calcium, dissolved & 40 & .97 & $<.001$ \\
Magnesium, dissolved & 40 & .96 & $<.001$ \\
Sodium, dissolved & 40 & .96 & $<.001$ \\
Chloride, dissolved & 40 & .87 & $<.001$ \\
Sulfate, dissolved & 40 & .91 & $<.001$ \\
Iron, dissolved & 40 & -.68 & $<.001$ \\
Manganese, dissolved & 40 & .15 & .348 \\
Selenium, dissolved & 31 & .82 & $<.001$ \\
\hline
\end{tabular}

rocks containing radioactive minerals and fallout of cosmic-ray-produced nuclides (Thatcher and others, 1977). Gross beta activity is used to screen for manmade radionuclides that are introduced through activities including nuclear weapons testing, discharge from nuclear power plants or medical facilities, leaching from a radionuclide waste depository, or other nuclear accidents (U.S. Environmental Protection Agency, 1986b). The proposed U.S. Environmental Protection Agency maximum contaminant level (MCL) for adjusted gross alpha radiation concentrations is $15 \mathrm{pCi} / \mathrm{L}$. Gross alpha concentrations were reported in micrograms per liter as natural uranium but can be converted to picocuries per liter by multiplying by 0.68 (Thatcher and others, 1977). Adjusted gross alpha represents total gross alpha measurements minus radium-226 and uranium measurements (U.S. Environmental Protection Agency, 1991). The proposed rule suggests that radium-226 and/or uranium concentrations should be obtained if unadjusted gross alpha concentration exceeds $15 \mathrm{pCi} / \mathrm{L}$. Radium-226 and uranium then can be subtracted from the unadjusted gross alpha concentration for comparison to the MCL. Dissolved-gross alpha concentrations exceeded $15 \mathrm{pCi} / \mathrm{L}$ for three separate analyses, twice at Las Animas and once at the Below John Martin Reservoir site. Total suspended gross alpha concentrations exceeded the MCL for 12 separate analyses at Avondale, Catlin Dam, and Las Animas. However, median gross alpha concentrations only exceeded the MCL at Catlin and Las Animas for total suspended concentrations. Total suspended gross alpha concentrations may sometimes reflect higher gross alpha concentrations than in filtered (dissolved) samples because of large amounts of suspended sediment in the samples. One component of gross alpha radiation is natural uranium. Natural uranium concentrations in the soil and ground water are relatively high downstream from Avondale and may contribute to the higher gross alpha concentrations at the downstream sites (Zielinski and others, 1995).

The proposed drinking-water standard for beta particle and photon activity is $4 \mathrm{mrem} / \mathrm{yr}$ (U.S. Environmental Protection Agency, 1993). If the gross beta particle activity is greater than $50 \mathrm{pCi} / \mathrm{L}$, the water samples should be analyzed to determine which radionuclides are present (U.S. Environmental Protection Agency, 1991). Four separate analyses for suspended total gross beta exceeded $50 \mathrm{pCi} / \mathrm{L}$ with two each occurring at Catlin Dam and Las Animas. All of the 
median dissolved and suspended total gross beta concentrations were less than $50 \mathrm{pCi} / \mathrm{L}$, and most were less than $10 \mathrm{pCi} / \mathrm{L}$.

\section{Pesticides}

Pesticides are widely used in agricultural areas and are of concern because of the potential to degrade water quality. Even in small concentrations, some pesticides are probable or possible carcinogens (U.S. Environmental Protection Agency, 1987). The distribution and concentration of pesticides in surfacewater systems are affected by sorption, bioaccumulation, and transformation processes (Smith and others, 1988). The characteristics of a compound, such as solubility or resistance to degradation, affect its mobility and occurrence in a given area. General pesticide usage, including insecticides and herbicides, has increased in the Arkansas River Basin in recent years. In 1989 , an estimated $843,000 \mathrm{lb}$ of herbicides, $357,000 \mathrm{lb}$ of insecticides, and 43,000 lb of fungicides and nematocides were applied in the southeast region of the State (Bohmont, 1991). A summary of agricultural pesticides commonly applied in the Arkansas River Basin is presented in table 26.

Pesticide samples were collected periodically at four sites on the Arkansas River during the study period. Five samples at each site were collected at Portland, Avondale, Catlin Dam, and Las Animas. One sample was collected at the Below John Martin Reservoir site. Pesticide sampling was scheduled during irrigation periods. The samples were analyzed for 35 insecticides, 29 herbicides, and polychlorinated biphenyls. Concentrations in nearly 97 percent of the samples analyzed were less than the analytical reporting limit. A summary of the detected pesticides in surface-water samples from the Arkansas River are presented in table 27. Of the seven compounds detected, two are organophosphorus insecticides and five are herbicides.

Organophosphorus insecticides are among the least environmentally persistent pesticides because of their relatively rapid chemical and biological degradation in both soil and surface-water systems. Diazinon was detected more frequently than malathion (nine detections compared to two detections), which is likely related to the fact that diazinon is one of the most persistent organophosphorus insecticides (Smith and others, 1988). Diazinon was detected in all five samples at Avondale, in three of the four samples at Catlin Dam, and in one of four samples at Las Animas. Diazinon is used primarily on onions and corn; malathion is used on alfalfa, corn, and beans and for mosquito control (Linda Coulter, Colorado Department of Agriculture, oral commun., 1994).

Herbicides are, in general, nonpersistent in the environment and are rapidly degraded in surface-water systems (Smith and others, 1988). The most commonly used herbicide in the lower Arkansas River Basin is 2,4-D (Linda Coulter, Colorado Department of Agriculture, oral commun., 1994). It was detected at each of the five surface-water sites but at levels less than the MCL of $70 \mu \mathrm{g} / \mathrm{L}$ (U.S. Environmental Protection Agency, 1993). The other herbicides bromacil, cyanazine, prometon, and 2,4-DP-were detected intermittently at concentrations at or near the detection level. Two of the herbicides, bromacil and prometon, are used almost exclusively on rights-of-way (Linda Coulter, Colorado Department of Agriculture, oral commun., 1994).

\section{Suspended Sediment}

A network of 12 sampling sites was established to determine the spatial variability of suspendedsediment concentrations and loads in the basin. All the sites were located on the main stem of the Arkansas River with the exception of Fountain Creek (table 1). Twenty-four to 28 water samples were collected at each of the 12 sites. Three other sites were sampled for suspended sediment only in response to various hydrological conditions observed at the time. In addition, suspended-sediment data collected periodically at Lower Badger Creek and Halfmoon Creek (pl. 1) were available for analysis. Instantaneous suspended-sediment load was computed by multiplying streamflow by concentration.

In the upper Arkansas River Basin, suspendedsediment concentrations showed downstream increases and large temporal variability but were relatively low in comparison to concentrations in the lower basin (fig. 30). Median suspended-sediment concentrations did not exceed $10 \mathrm{mg} / \mathrm{L}$ from Leadville to Wellsville but increased significantly $(\alpha=0.05)$ downstream from Wellsville to Portland. The median suspended-sediment concentrations at Parkdale and Portland were 26 and $56 \mathrm{mg} / \mathrm{L}$, respectively. The large increase in suspended-sediment concentrations down- 
Table 26. Agricultural pesticides commonly applied in the Arkansas River Basin (modified from Lorenz Sutherland, U.S. Department of Agriculture, written commun., 1990)

[Little or no pesticide application occurs during January, February, October, November, or December]

\begin{tabular}{|c|c|c|c|}
\hline $\begin{array}{c}\text { Month of } \\
\text { application }\end{array}$ & $\begin{array}{l}\text { Designated } \\
\text { crop }\end{array}$ & Target pest & Common chemical compound name ${ }^{1}$ \\
\hline \multirow[t]{3}{*}{ March } & Alfalfa & Weeds & Paraquat \\
\hline & Onions & Weeds & Chlorthal dimethyl \\
\hline & Small grains & Russian wheat aphid & Disulfoton \\
\hline \multirow[t]{3}{*}{ April } & Corn & Rootworm & Carbofuran, terbufos, phorate \\
\hline & & Weeds & Pendimethalin, metolachlor, alachlor, cyanazine, dimethylamine salt of dicamba \\
\hline & Small grains & Russian wheat aphid & Disulfoton \\
\hline \multirow[t]{7}{*}{ May } & Alfalfa & Weevil & Carbofuran, parathion, chlorpyrifos \\
\hline & Corn & Rootworm & Carbofuran, terbufos, phorate \\
\hline & & Weeds & Pendimethalin, metolachlor, alachlor, cyanazine, dimethylamine salt of dicamba \\
\hline & Small grains & Russian wheat aphid & Disulfoton \\
\hline & Onions & Weeds & Oxyfluorfen, fluazifop-butyl, sethoxydim \\
\hline & & Thrips & Cypermethrin \\
\hline & Melons & Cucumber beetle & Carbaryl, parathion, esfenvalerate \\
\hline \multirow[t]{5}{*}{ June } & Corn & Weeds & Dimethylamine salt of dicamba, 2,4-D \\
\hline & Onions & Weeds & Oxyfluorfen, fluazifop-butyl, sethoxydim \\
\hline & & Thrips & Cypermethrin \\
\hline & & Disease & Mancozeb, chlorothalonil, copper sulfate \\
\hline & Melons & Cucumber beetle & Carbaryl, parathion, esfenvalerate \\
\hline \multirow[t]{7}{*}{ July } & Corn & Mites & Propargite \\
\hline & Onions & Weeds & Oxyfluorfen, fluazifop-butyl, sethoxydim \\
\hline & & Thrips & Cypermethrin \\
\hline & & Disease & Mancozeb, chlorothalonil, copper sulfate \\
\hline & Melons & Disease & Mancozeb, chlorothalonil \\
\hline & Sorghum & Greenbugs & Parathion, chlorpyrifos \\
\hline & Pinto beans & Disease & Chlorothalonil, mancozeb \\
\hline \multirow[t]{7}{*}{ August } & Corn & Mites & Propargite \\
\hline & & Borers & Carbofuran, permethrin \\
\hline & Onions & Weeds & Fluazifop-butyl \\
\hline & & Disease & Iprodione, mancozeb, chlorothalonil, copper sulfate \\
\hline & Melons & Disease & Mancozeb, chlorothalonil \\
\hline & Pinto beans & Disease & Chlorothalonil, mancozeb \\
\hline & Sorghum & Greenbugs & Parathion, chlorpyrifos \\
\hline \multirow[t]{3}{*}{ September } & Onions & Weeds & Oxyfluorfen, fluazifop-butyl, sethoxydim \\
\hline & & Thrips & Cypermethrin \\
\hline & & Disease & Mancozeb, chlorothalonil, copper sulfate \\
\hline
\end{tabular}

\footnotetext{
'Chemical composition from 1993 Farm Chemicals Handbook, Meister Publishing Company, Willoughby, Ohio.
} 
Table 27. Summary of detected pesticides for selected water-quality sites in the Arkansas River, April 1990-March 1993

$[\mu \mathrm{g} / \mathrm{L}$, microgram per liter $]$

\begin{tabular}{|c|c|c|c|c|c|}
\hline $\begin{array}{l}\text { Compound } \\
\text { name }\end{array}$ & $\begin{array}{l}\text { Number of } \\
\text { samples } \\
\text { analyzed }\end{array}$ & $\begin{array}{l}\text { Number of } \\
\text { detections }\end{array}$ & $\begin{array}{c}\text { Maximum } \\
\text { concentration } \\
\text { detected } \\
(\mu \mathrm{g} / \mathrm{L})\end{array}$ & $\begin{array}{l}\text { Reporting limit } \\
\qquad(\mu \mathrm{g} / \mathrm{L})\end{array}$ & $\begin{array}{l}\text { Type of } \\
\text { Pesticide }\end{array}$ \\
\hline \multicolumn{6}{|c|}{ Portland } \\
\hline 2,4-D & 5 & 2 & 0.05 & 0.01 & Herbicide \\
\hline \multicolumn{6}{|c|}{ Avondale } \\
\hline Bromacil & 4 & 1 & .7 & .2 & Herbicide \\
\hline Diazinon & 5 & 5 & .16 & .01 & Insecticide \\
\hline Malathion & 5 & 1 & .04 & .01 & Insecticide \\
\hline Prometon & 5 & 2 & .2 & .2 & Herbicide \\
\hline $2,4-D$ & 5 & 5 & .33 & .01 & Herbicide \\
\hline 2,4-DP & 5 & 2 & .01 & .01 & Herbicide \\
\hline \multicolumn{6}{|c|}{ Catlin Dam } \\
\hline Diazinon & 4 & 3 & .01 & .01 & Insecticide \\
\hline Prometon & 5 & 1 & .1 & .1 & Herbicide \\
\hline $2,4-D$ & 4 & 2 & .04 & .01 & Herbicide \\
\hline \multicolumn{6}{|c|}{ Las Animas } \\
\hline Bromacil & 4 & 1 & .7 & .2 & Herbicide \\
\hline Cyanazine & 5 & 1 & .1 & .1 & Herbicide \\
\hline Diazinon & 4 & 1 & .02 & .01 & Insecticide \\
\hline Malathion & 5 & 1 & .01 & .01 & Insecticide \\
\hline Prometon & 5 & 2 & .2 & .2 & Herbicide \\
\hline $2,4-D$ & 5 & 4 & .3 & .01 & Herbicide \\
\hline \multicolumn{6}{|c|}{ Below John Martin Reservoir } \\
\hline Prometon & 1 & 1 & .1 & .1 & Herbicide \\
\hline $2,4-D$ & 1 & 1 & .04 & .01 & Herbicide \\
\hline
\end{tabular}

stream from Wellsville probably is attributable to changing geology and local land use. Excessive erosion on rangeland in the Badger Creek (pl. 1) watershed has been identified as a substantial source of suspended sediment to the upper Arkansas River downstream from Wellsville (Valentine and Carochi, 1993). Tributaries that drain sedimentary rocks and overgrazed lands also are likely sources of sediment to the Arkansas River, particularly during periods of high runoff. Suspended-sediment concentrations generally were much larger during snowmelt-runoff regimes, probably in response to tributary inflow and suspension of fluvial sediment. Suspended-sediment concentrations also can increase substantially during periods of elevated runoff from storm events; the largest measured concentration in the upper basin $(1,650$ $\mathrm{mg} / \mathrm{L}$ ) occurred in a storm-runoff sample collected at Parkdale during August 1992.
Suspended-sediment concentrations in the lower Arkansas River Basin generally were much larger than those in the upper basin (fig. 30). Initially, median suspended-sediment concentrations decreased downstream from Pueblo Reservoir (19 mg/L at Pueblo), presumably because of sediment deposition in the reservoir, but increased significantly $(\alpha=0.05)$ downstream to Avondale $(257 \mathrm{mg} / \mathrm{L})$ and to Catlin Dam $(724 \mathrm{mg} / \mathrm{L})$. The downstream increases are probably attributable to tributary inflow and suspension of fluvial sediment; Fountain Creek had a median suspended-sediment concentration of $436 \mathrm{mg} / \mathrm{L}$. Median suspended-sediment concentrations decreased significantly $(\alpha=0.05)$ between Las Animas and the site immediately downstream of John Martin Reservoir, presumably due to deposition in the reservoir. Concentrations at most sites in the lower basin were largest during the post-snowmelt runoff regime. 


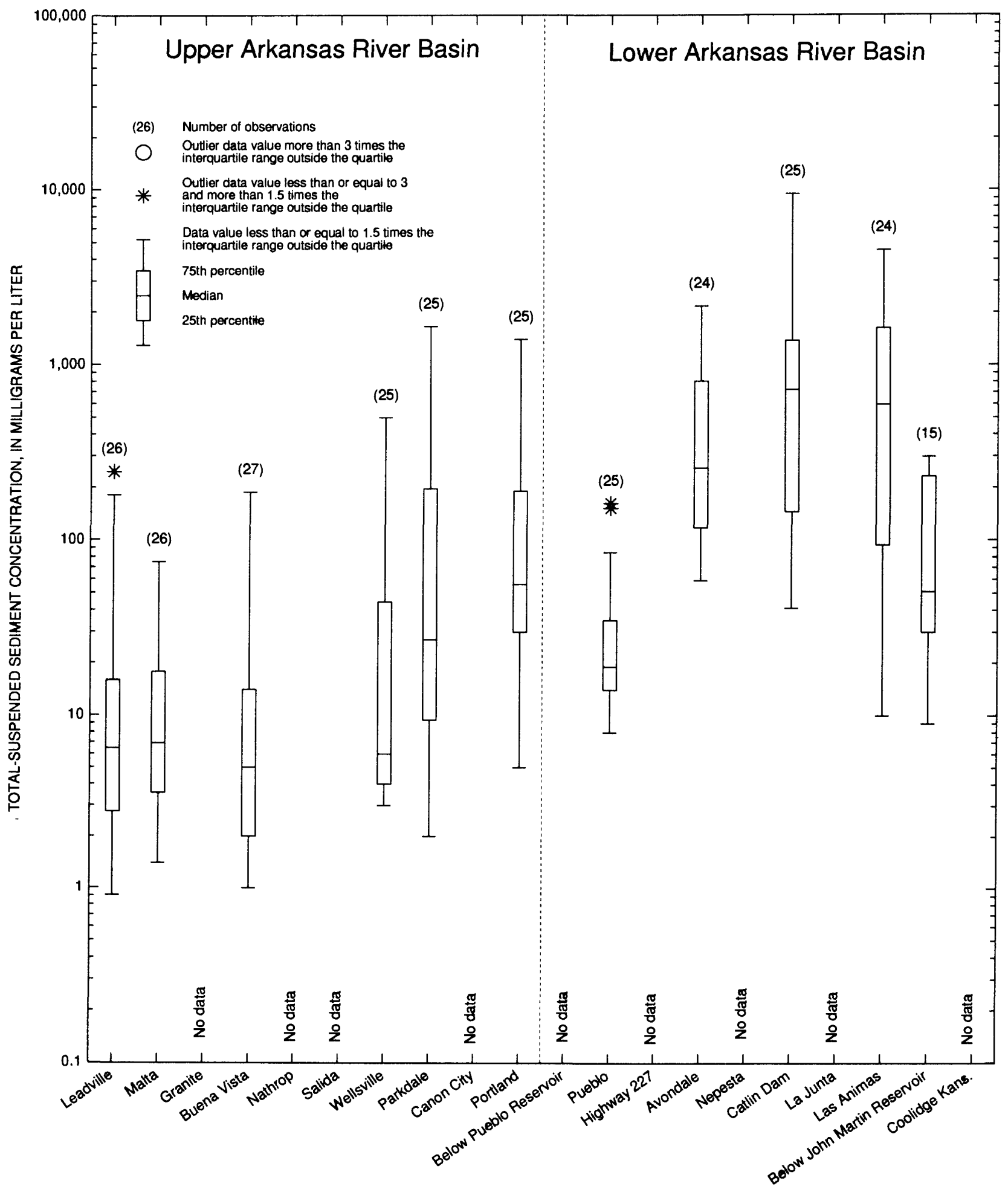

Figure 30. Variations in total-suspended-sediment concentrations in the Arkansas River, April 1990-March 1993. 
Runoff from thunderstorms can have a large effect on suspended-sediment concentrations in the lower basin. Two sampled storm events at Catlin Dam illustrate the potential for transport of large sediment loads from tributary drainages to the lower Arkansas River. In July 1991, a fast-moving thunderstorm that was localized in the Apishapa River drainage produced suspended-sediment concentrations in excess of $20,000 \mathrm{mg} / \mathrm{L}$ in the Apishapa River (pl. 1). Downstream at Catlin Dam, a sharp increase in streamflow and suspended sediment was observed as flow from the Apishapa River reached the site. A comparison of suspended-sediment concentrations and loads at Catlin Dam during the storm runoff and during a similar streamflow in June 1991 (peak flow) showed large differences; concentrations and loads were nearly five times larger from storm runoff than those observed during the peak flow in June (table 28). In August 1992, concentrations of suspended sediment at Catlin Dam following a storm event were about 13 times greater than concentrations measured at a similar flow one month earlier (table 28).

\section{Bacteria}

Water samples were collected and analyzed for fecal-coliform bacteria, total-coliform bacteria, and fecal-streptococcal bacteria at selected sites in the Arkansas River Basin. Twenty-one to 24 samples were collected for fecal-coliform and fecal-streptococcal bacteria at 15 main-stem sites and 1 tributary site throughout the basin. Sixteen to 22 samples were collected for total-coliform bacteria at 8 main-stem sites in the upper basin only. Coliform organisms, while relatively harmless themselves, are usually present in water that contains enteric pathogens and, thus, can serve as an indicator. Fecal-coliform analysis is a more definitive test for recent fecal contamination, and fecal coliform is the standard organism used for testing sewage, untreated public water supplies, and primary contact waters. Fecal streptococci are used as indicators of contamination of water because the normal habitat of these organisms is the intestines of man and animals. Fecal-streptococci data verify fecal pollution and may provide additional information concerning the probable origin of the pollution (Britton and Greeson, 1987).

\section{Concentrations of fecal coliform in the}

Arkansas River generally increased downstream (fig. 31) and were relatively low in comparison to stream water-quality standards. Median concentrations of fecal coliform were less than the biological standard for all sampled main-stem sites. Typically, the standard is 2,000 colonies $/ 100 \mathrm{~mL}$ but can be as low as 200 colonies $/ 100 \mathrm{~mL}$ (Colorado Department of Health, 1994). The highest median concentration occurred at Las Animas (162 colonies/100 mL). Median fecal-coliform concentrations tended to be highest during snowmelt runoff and post-snowmelt runoff (fig. 31). Median fecal-coliform concentrations were larger in the lower basin, particularly during the post-snowmelt runoff flow regime. In general, fecalstreptococci concentrations also increased downstream. Median concentrations ranged from 9.5 colonies $/ 100 \mathrm{~mL}$ at Leadville to 612 colonies $/ 100 \mathrm{~mL}$ at

Table 28. Comparison of streamflow and suspended-sediment concentrations and loads for storms and other streamflow regimes at Catlin Dam

\begin{tabular}{llccc}
\hline \multicolumn{1}{c}{ Date } & \multicolumn{1}{c}{$\begin{array}{c}\text { Streamflow } \\
\text { characterization }\end{array}$} & $\begin{array}{c}\text { Streamflow, } \\
\text { in cubic feet } \\
\text { per second }\end{array}$ & $\begin{array}{c}\text { Concentration, } \\
\text { in milligrams } \\
\text { per liter }\end{array}$ & $\begin{array}{c}\text { Instantaneous } \\
\text { load, } \\
\text { in tons per day }\end{array}$ \\
\hline June 11, 1991 & Snowmelt runoff & July 2, 1991 & & \\
July 2, 1991 & Storm & 1,850 & 959 & 4,790 \\
& Percent difference & -5 & 4,770 & 22,500 \\
July 17, 1992 & Post-snowmelt runoff & August 18, 1992 & 397 & 370 \\
August 18, 1992 & Storm & 581 & 724 & 1,140 \\
& Percent difference & 613 & 9,469 & 15,700 \\
& 5.5 & 1,208 & 1,277 \\
\hline
\end{tabular}



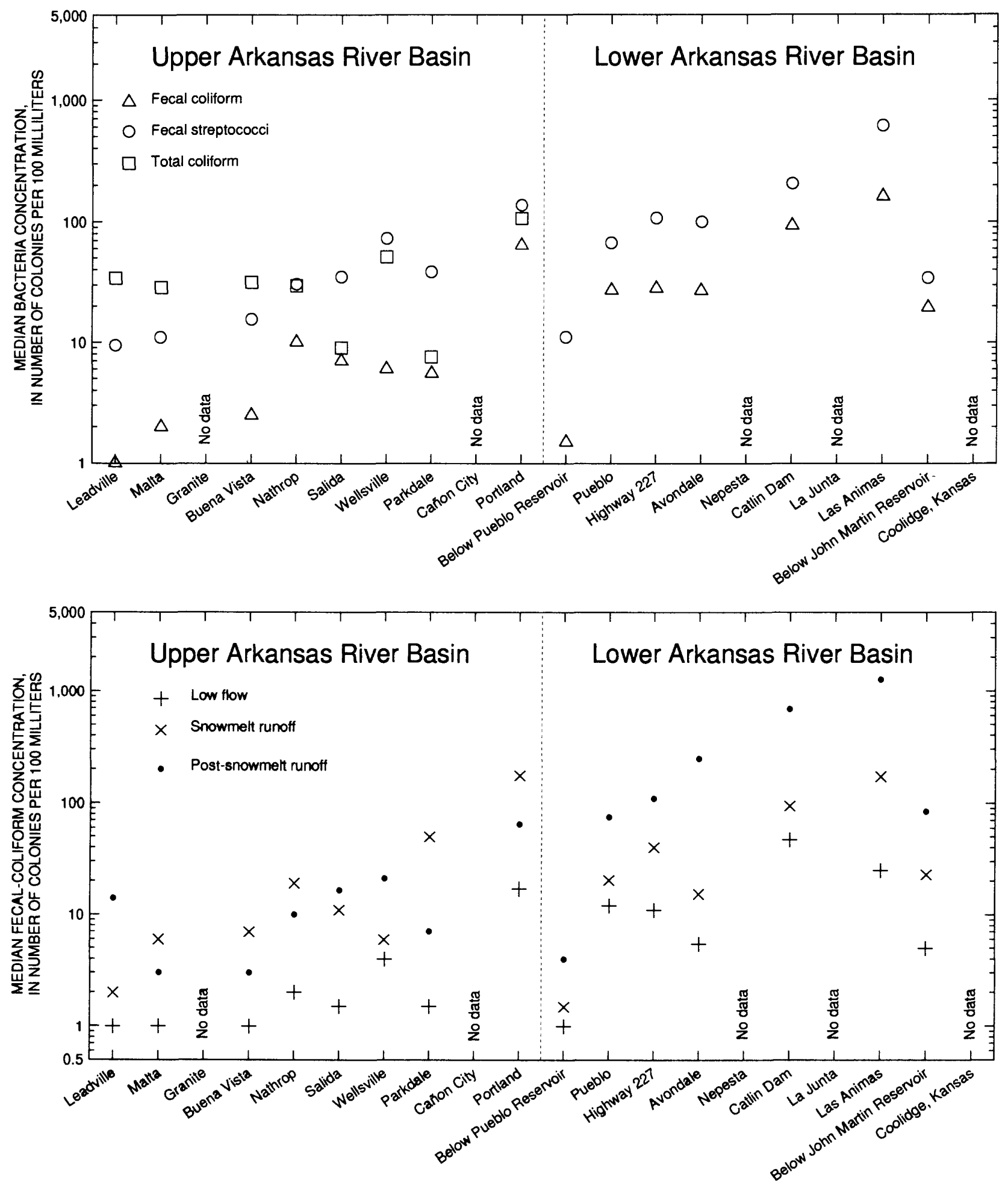

Figure 31. Median fecal-coliform, fecal-streptococci, and total-coliform bacteria concentrations and median fecal-coliform concentrations by streamflow regime in the Arkansas River, April 1990-March 1993. 
Las Animas. Temporally, fecal-streptococci concentrations in the Arkansas River were similar to that of fecal coliform. Median total-coliform concentrations in the upper basin were low and ranged from 7.5 colonies $/ 100 \mathrm{~mL}$ at Parkdale to 107 colonies $/ 100 \cdot \mathrm{mL}$ at Portland. The highest concentrations occurred during snowmelt runoff.

\section{SUMMARY}

This report describes the water-quality conditions in the Arkansas River Basin in southeastern Colorado between April 1990 and March 1993. Discussions focus on the site-to-site variability of water quality in the main stem of the river in the upper basin (upstream from Pueblo) and in the lower basin (from Pueblo to the Colorado-Kansas State line). Water-quality data commonly are presented by streamflow regime. In general, the data were separated into three streamflow regimes that are defined as: low flow (October-April), snowmelt runoff (May-June), and post-snowmelt runoff (July-September). For trace elements in the upper basin, data were further separated into a pre-snowmelt runoff period in April; therefore, the low-flow regime for trace elements in the upper basin is defined as October through March.

Generally, the waters of the Arkansas River were well oxygenated. The $\mathrm{pH}$ of the river was near neutral to slightly alkaline. Dissolved-solids concentrations in the Arkansas River showed distinct spatial variability and were influenced by many factors, including runoff from snowmelt or rainfall, geology, land and water use, mine drainage, and ground-water inflow. Overall, median dissolved-solids concentrations in the main stem of the river ranged from $62.5 \mathrm{mg} / \mathrm{L}$ at Granite to $3,825 \mathrm{mg} / \mathrm{L}$ at Coolidge. The downstream increase in dissolved-solids concentrations was caused by a transition in geology from igneous and metamorphic rocks to sedimentary rocks and by the concentrating effects associated with the use and reuse of water for irrigation.

In general, concentrations of all six major ions increased downstream. In the upper basin, calcium and bicarbonate were the dominant major ions. From Portland to Below Pueblo Reservoir, the water changed from a calcium bicarbonate type to a calcium sulfate type, probably as a result of contact with marine shales in the area. In the lower basin, the water changed from a calcium sulfate type to a mixed water type at Coolidge.

The primary cause of elevated trace-element concentrations in the upper Arkansas River is metalladen drainage from abandoned mines and mine tailings. The spatial and temporal variability of trace-element concentrations at main-stem sites in the upper Arkansas River probably was influenced by (1) distance from the Leadville area, (2) dilution by tributaries, (3) degree of partitioning between the dissolved and particulate phases, and (4) deposition and resuspension of fluvial sediment. Generally, concentrations of dissolved trace elements in the Arkansas River decreased from Leadville to Portland. Dissolved cadmium, copper, lead, manganese, and zinc concentrations did increase between Leadville and Malta, but these elevated concentrations were subsequently diluted by inflow from Twin Lakes Reservoir. Temporally, dissolved cadmium, iron, manganese, and zinc concentrations typically were largest during early-snowmelt runoff; total-recoverable cadmium, copper, iron, lead, manganese, and zinc concentrations generally were largest during snowmelt runoff when resuspension of fluvial sediments occurred. Concentrations of cadmium, copper, manganese, and zinc decreased significantly $(\alpha=0.05)$ at several sites in the upper Arkansas River Basin following the completion of water-treatment facilities at two mine-drainage tunnels in the Leadville area. Chronic and acute stream-water-quality standards were exceeded in samples collected at several upperbasin sites; however, the vast majority of exceedances occurred prior to the installation of the mine-drainage water-treatment facilities. Tributaries downstream from Granite generally did not contribute substantial loads to the river, although several tributaries upstream from Granite (California Gulch, Lake Fork, and Lake Creek) frequently contributed substantial trace-element loads to the river.

Sources of trace elements in the lower basin include inflow from the mining-affected upper basin, point and nonpoint sources associated with urban land use, irrigation return flows associated with agricultural land use, and tributary inflow. Concentrations of dissolved cadmium, chromium, copper, lead, and nickel generally were near or less than their reporting limits at most sites. Dissolved-selenium concentrations, however, comprised about 90 percent of the total-recoverable selenium concentration at most sites. Total-recoverable selenium concentrations increased 
from Pueblo to Las Animas and frequently exceeded the stream-water-quality standard $(10 \mathrm{mg} / \mathrm{L})$ at Catlin Dam and at Las Animas. Most exceedances occurred during the low-flow regime. Dissolved-manganese and dissolved-iron concentrations generally were small at most sites; however, during the low-flow regime, substantial increases in dissolved-manganese and dissolved-iron concentrations were measured immediately downstream from John Martin Reservoir. Anoxic conditions in John Martin Reservoir during the winter are suspected to result in the dissolution of iron and manganese from bottom sediments, thereby resulting in increased concentrations in the water column. Concentrations of most total-recoverable trace elements generally increased from Pueblo to Las Animas and were largest during snowmelt runoff and post-snowmelt runoff. Resuspension of fluvial sediment was presumed to be a major cause of the downstream increases. Additionally, a few water samples collected from major tributaries in the lower basin during storm-runoff events had very large concentrations of most trace elements. This indicates that tributary storm runoff probably is a major source of trace elements in the lower basin.

Median ammonia concentrations in the Arkansas River ranged from a minimum of $0.010 \mathrm{mg} / \mathrm{L}$ at Leadville to maximum of $0.145 \mathrm{mg} / \mathrm{L}$ at the Below John Martin Reservoir site; median nitrate concentrations at main-stem sites ranged from a minimum of $0.020 \mathrm{mg} / \mathrm{L}$ at Granite to a maximum of $2.4 \mathrm{mg} / \mathrm{L}$ at La Junta. High concentrations of ammonia downstream from John Martin Reservoir, particularly during low-flow regimes, are indicative of anoxic conditions in the reservoir. Ammonia and nitrate concentrations generally increased downstream but were low in comparison to State and Federal standards. Nitrate concentrations were higher during low flow, whereas ammonia concentrations were generally similar throughout the year.

Median total-phosphorus concentrations were relatively low in the upper basin, but they exceeded the Environmental Protection Agency recommendation for total-phosphorus concentration in rivers $(0.10 \mathrm{mg} / \mathrm{L})$ at three sites in the lower basin. At Las Animas, which is immediately upstream from John Martin Reservoir, the median total-phosphorus concentration was $0.10 \mathrm{mg} / \mathrm{L}$; the Environmental Protection Agency recommends that total-phosphorus concentrations in rivers entering a reservoir not exceed
$0.05 \mathrm{mg} / \mathrm{L}$. There was no distinct temporal pattern in the phosphorus concentrations.

Uranium concentrations increased downstream in the Arkansas River, and large increases occurred in the lower basin. The use and reuse of irrigation water in the lower basin increase the amount of time the water can interact with soils and rock, resulting in increased concentrations of dissolved uranium. Instantaneous dissolved natural uranium concentrations exceeded the proposed drinking-water standard at two sites, once at the Las Animas site $(36 \mathrm{mg} / \mathrm{L})$ and twice at the Below John Martin Reservoir site $(29 \mathrm{mg} / \mathrm{L})$. The median value for dissolved uranium at Below John Martin Reservoir also exceeded the proposed drinking-water standard.

Pesticides are widely used in agricultural areas and are of concern because of the potential to degrade water quality. Most of the pesticide samples submitted for analyses during the study period were reported as having concentrations less than analytical reporting limits. The herbicide 2,4-D was detected at each of the five sampled main-stem sites but at concentrations less than maximum contaminant levels.

Suspended-sediment concentrations in the Arkansas River upstream from Pueblo Reservoir were relatively low but increased significantly downstream. Median suspended-sediment concentrations increased significantly between Parkdale and Portland and between Pueblo and Catlin Dam. The downstream increases are attributable to changes in geology, tributary inflow, and resuspension of fluvial sediment. During periods of elevated runoff, suspended-sediment concentrations can increase by several times; the largest measured concentration $(1,650 \mathrm{mg} / \mathrm{L})$ in the upper basin occurred in a storm-runoff sample collected at Parkdale. Runoff from thunderstorms also can have a large effect on suspended-sediment concentrations in the lower Arkansas River.

Fecal-coliform, fecal-streptococci, and totalcoliform bacteria concentrations in the Arkansas River increased downstream; concentrations were relatively low in comparison to stream-water-quality standards. Fecal-coliform concentrations were substantially larger in the lower basin. The highest median fecalcoliform concentration of 162 colonies $/ 100 \mathrm{~mL}$ occurred at Las Animas, which was less than the 2,000 colonies $/ 100 \mathrm{~mL}$ standard. 


\section{SELECTED REFERENCES}

Abbott, P.O., 1985, Description of water-systems operations in the Arkansas River basin, Colorado: U.S. Geological Survey Water-Resources Investigations Report 85-4092, $67 \mathrm{p}$.

Bohmont, B.L., 1991, Colorado pesticide use survey, estimated use, 1989: Fort Collins, Colorado State University, $43 \mathrm{p}$.

Britton, L.J. and Greeson, P.E., eds., 1987, Methods for collection and analysis of aquatic biological and microbiological samples: U.S. Geological Survey Techniques of Water-Resources Investigations, book 5 , chap. A4, 363 p.

Brown, T.H., 1991, Solubility, sorption, and redox relationships for selenium in reclaimed environments, in Proceedings of the 1990 Billings Land Reclamation Symposium on Selenium in Arid and Semiarid Environments, Western United States: U.S. Geological Survey Circular 1064, p. 25-33.

Burns, A.W., 1985, Selected hydrographs and statistical analyses characterizing the water resources of the Arkansas River basin, Colorado: U.S. Geological Survey Water-Resources Investigations Report 85-4264, 199 p.

Cain, Doug, 1985, Quality of the Arkansas River and irrigation-return flows in the lower Arkansas River valley, Colorado: U.S. Geological Survey WaterResources Investigations Report 84-4273, 85 p.

Clark, M.L., and Lewis, M.E., 1997, Metal speciation in the upper Arkansas River, Colorado, 1990-93: U.S. Geological Survey Water-Resources Investigations Report 96-4282, 24 p.

Clements, W.H., 1991, Fate and effects of heavy metals on the Arkansas River. Colorado Water Resources Research Institute Completion Report No. 163, 24 p.

Colorado Department of Agriculture, 1981, Colorado agriculture statistics: Denver, Colorado Department of Agriculture, $162 \mathrm{p}$.

Colorado Department of Health, 1994, Classifications and numeric standards Arkansas River Basin: Denver, Colorado Department of Health, $78 \mathrm{p}$.

Crouch, T.M., Cain, Doug, Abbott, P.O., Penley, R.D., and Hurr, R.T., 1984, Water-resources appraisal of the upper Arkansas River Basin from Leadville to Pueblo, Colorado: U.S. Geological Survey Water-Resources Investigations Report 82-4114, $123 \mathrm{p}$.

Dash, Russell, and Ortiz, Roderick F., 1996, Water-quality data for the Arkansas River Basin, southeastern Colorado, 1990-93: U.S. Geological Survey Open-File Report 95-464, 137 p.

Fenneman, N.M., 1931, Physiography of the Western United States: New York, McGraw-Hill, 534 p.
Gerhardt, A., 1993, Review of impact of heavy metals on stream invertebrates with special emphasis on acid conditions: Water, Air, and Soil Pollution, v. 66, p. $289-314$.

Hatten, H.J., 1969, Selenium in the Upper Cretaceous Niobrara Formation and Pierre Shale of south-central Colorado, in Abstracts for 1968 [abs.]: Geological Society of America Special Paper 121, p. 606.

Hem, J.D., 1985, Study and interpretation of the chemical characteristics of natural water: U.S. Geological Survey Water-Supply Paper 2254, 263 p.

Kimball, Briant A., Callender, Edward, and Axtmann, Ellen V., 1995, Effects of colloids on metal transport in a river receiving acid mine drainage, upper Arkansas River, Colorado, U.S.A.: Applied Geochemistry, v. 10, p. 282-306.

Lewis, M.E., and Edelmann, P.F., 1994, Physical, chemical, and biological characteristics of Pueblo Reservoir, Colorado, 1985-89: U.S. Geological Survey WaterResources Investigations Report 94-4097, $71 \mathrm{p}$.

Miles, D.L., 1977, Salinity in the Arkansas Valley of Colorado: U.S Environmental Protection Agency and Colorado State University, Interagency Agreement, EPA-IAG-D4-0544, $80 \mathrm{p}$.

Moore, J.W., and Ramamoorthy, S., 1984, Heavy metals in natural waters: New York, Springer-Verlag, 268 p.

Moran, R.E., and Wentz, D.A., 1974, Effect of metal-mine drainage on water quality in selected areas of Colorado 1972-73: Colorado Water Conservation Board, Water-Resources Circular 25, $250 \mathrm{p}$.

Mueller, D.K., DeWeese, L.R., Garner, A.J., and Spruill, T.B., 1991, Reconnaissance investigation of water quality, bottom sediment, and biota associated with irrigation drainage in the middle Arkansas River Basin, Colorado and Kansas, 1988-89: U.S. Geological Survey Water-Resources Investigations Report 91-4060, $84 \mathrm{p}$.

National Technical Advisory Committee to the Secretary of the Interior, 1968. Water quality criteria: U.S. Government Printing Office, Washington, D.C., 232 p.

Oremland, R.S., Hollibaugh, J.T., Maest, A.S., Presser, T.S., Miller, L.G., and Culbertson, C.W., 1989, Selenate reduction to elemental selenium by anaerobic bacteria in sediments and culture-Biogeochemical significance of a novel, sulfate-independent respiration: Applied and Environmental Microbiology, v. 55, no. 9, p. 2333-2343.

Pettijohn, F.J., 1949, Sedimentary rocks: New York, Harper \& Brothers Publishers. $526 \mathrm{p}$.

SAS Institute, Inc., 1985, SAS user's guide - Statistics (5th ed.): Cary, N.C., SAS Institute, 956 p. 
Schultz, L.G., Tourtelot, H.A., Gill, J.R., and Boerngen, J.G., 1980, Composition and properties of the Pierre Shale and equivalent rocks, northern Great Plains region: U.S. Geological Survey Professional Paper 1064-B, 113 p.

Shannon, Jr., S.S., 1979, Uranium hydrogeochemical and stream sediment reconnaissance of the Lamar quadrangle, Colorado, including concentrations of fortythree additional elements: Los Alamos National Lab Informal Report LA-7342-MS, USDOE Report GJBX 64 (79).

Sine, Charlotte, ed., 1993, Farm chemicals handbook: Willoughby, $\mathrm{OH}$, Meister Publishing Company.

Smith, J.A., Witkowski, P.J., and Fusillo, T.V., 1988, Manmade organic compounds in the surface water of the United States-A review of current understanding: U.S. Geological Survey Circular 1007, 92 p.

Snodgrass, W.J., 1980, Distribution and behavior of nickel in the aquatic environment, in Nriagu, J.O., ed, Nickel in the environment: New York, John Wiley, p. 203-274.

Thatcher, L.L., Janzer, V.J., and Edwards, K.W., eds., 1977, Methods for determination of radioactive substances in water and fluvial sediments: U.S. Geological Survey Techniques of Water-Resources Investigations, book 5 , chap. A5, 95 p.

Turekian, K.K., and Wedepohl, K.H., 1961, Distribution of the elements in some major units of the earth's crust: Geological Society of America Bulletin, v. 72, no. 2, p. $175-191$.

Tweto, Ogden, 1968, Geologic setting and interrelationships of mineral deposits in the Mountain Province of Colorado and south-central Wyoming, in Ridge, J.D., ed., Ore deposits of the United States, 1933-1967: New York, American Institute of Mining, Metallurgical, and Petroleum Engineers, v. 1, p. 551-588.

Ugland, R.C., Cochran, B.J., Hiner, M.M., and Steger, R.D., 1991, Water resources data for Colorado, water year 1990 , v. 1, Missouri River Basin, Arkansas River Basin, and Rio Grande Basin: U.S. Geological Survey Water-Data Report CO-90-1, 489 p. 1992, Water resources data for Colorado, water year 1991, v. 1, Missouri River Basin, Arkansas River Basin, and Rio Grande Basin: U.S. Geological Survey Water-Data Report CO-90-1, 399 p.
1993, Water resources data for Colorado, water year 1992, v. 1, Missouri River Basin, Arkansas River Basin, and Rio Grande Basin: U.S. Geological Survey Water-Data Report CO-92-1, 331 p.

1994, Water resources data for Colorado, water year 1993, Volume 1. Missouri River Basin, Arkansas River Basin, and Rio Grande Basin: U.S. Geological Survey Water-Data Report CO-93-1, 518 p.

U.S. Bureau of the Census, 1991, 1990 Census of Population and Housing, Population and Housing Unit Counts-Colorado: Washington, D.C., 53 p.

U.S. Environmental Protection Agency, 1986a, Quality criteria for water: EPA 440/5-86-001, $256 \mathrm{p}$.

$-1986 \mathrm{~b}$, National primary drinking water regulation, radionuclides (section 141.50 of part 141), proposed rule: Federal Register, v. 51, no. 189, September 30, 1986, p. 34836-34862.

1987, National primary drinking water regulations, maximum contaminant levels for organic contaminants (section 141.60 or part 141) and maximum contaminant level goals for organic contaminants (section 141.50 of part 141), final rule: Federal Register, v. 52, no. 130 , July 8,1987 , p. 25690-25717.

1991, National primary drinking water regulations, radionuclides (40 CFR, parts 141 and 142), proposed rule: Federal Register, v. 56 , no. 138 , July 18,1991 , p. 33050 .

1993, Drinking-water regulations and health advisories: December 1993, 11 p.

Valentine, John, and Carochi, John, 1993, Making a difference-Agencies can, will, do work together to solve nonpoint source pollution problems: Journal of Soil and Water Conservation, September-October, p. $401-406$.

Wentz, D.A., 1974, Effect of mine drainage on the quality of streams in Colorado, 1971-1972: Colorado Water Conservation Board, Water-Resources Circular 21, $117 \mathrm{p}$.

Zielinski, R.A., Asher-Bolinder, S., and Meier, A.L., 1995, Uraniferous waters of the Arkansas River valley, Colorado, U.S.A.-A function of geology and land use: Applied Geochemistry, v. 10, p. 133-144. 